\title{
ॠUSGS
}

Xests

Prepared in cooperation with the U.S. Department of Energy, National Nuclear Security Administration, Nevada Site Office, Office of Environmental Management under Interagency Agreement, DE-A152-07NA28100

Groundwater Flow Systems at the Nevada Test Site, Nevada: A Synthesis of Potentiometric Contours, Hydrostratigraphy, and Geologic Structures

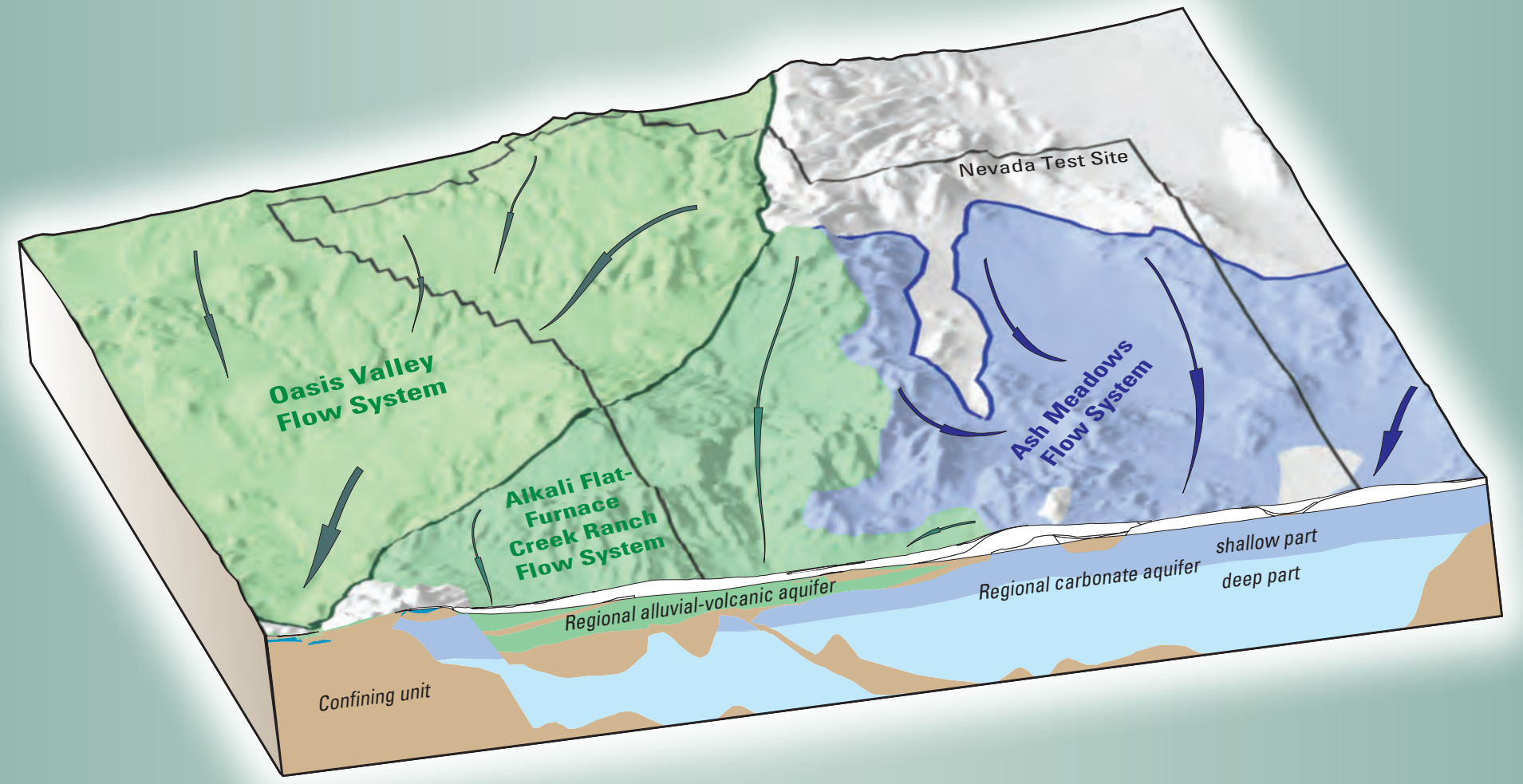

Professional Paper 1771 



\section{Groundwater Flow Systems at the Nevada Test Site, Nevada: A Synthesis of Potentiometric Contours, Hydrostratigraphy, and Geologic Structures}

By Joseph M. Fenelon, Donald S. Sweetkind, and Randell J. Laczniak

Prepared in cooperation with the U.S. Department of Energy, National

Nuclear Security Administration, Nevada Site Office, Office of Environmental

Management under Interagency Agreement, DE-A152-07NA28100

Professional Paper 1771 


\title{
U.S. Department of the Interior \\ KEN SALAZAR, Secretary \\ U.S. Geological Survey \\ Marcia K. McNutt, Director
}

\section{U.S. Geological Survey, Reston, Virginia: 2010}

\begin{abstract}
For more information on the USGS - the Federal source for science about the Earth, its natural and living resources, natural hazards, and the environment, visit http://www.usgs.gov or call 1-888-ASK-USGS

For an overview of USGS information products, including maps, imagery, and publications, visit http://www.usgs.gov/pubprod

To order this and other USGS information products, visit http://store.usgs.gov
\end{abstract}

Any use of trade, product, or firm names is for descriptive purposes only and does not imply endorsement by the U.S. Government.

Although this report is in the public domain, permission must be secured from the individual copyright owners to reproduce any copyrighted materials contained within this report.

Suggested citation:

Fenelon, J.M., Sweetkind, D.S., and Laczniak, R.J., 2010, Groundwater flow systems at the Nevada Test Site, Nevada: A synthesis of potentiometric contours, hydrostratigraphy, and geologic structures: U.S. Geological Survey Professional Paper 1771, 54 p., 6 pls. 


\section{Contents}

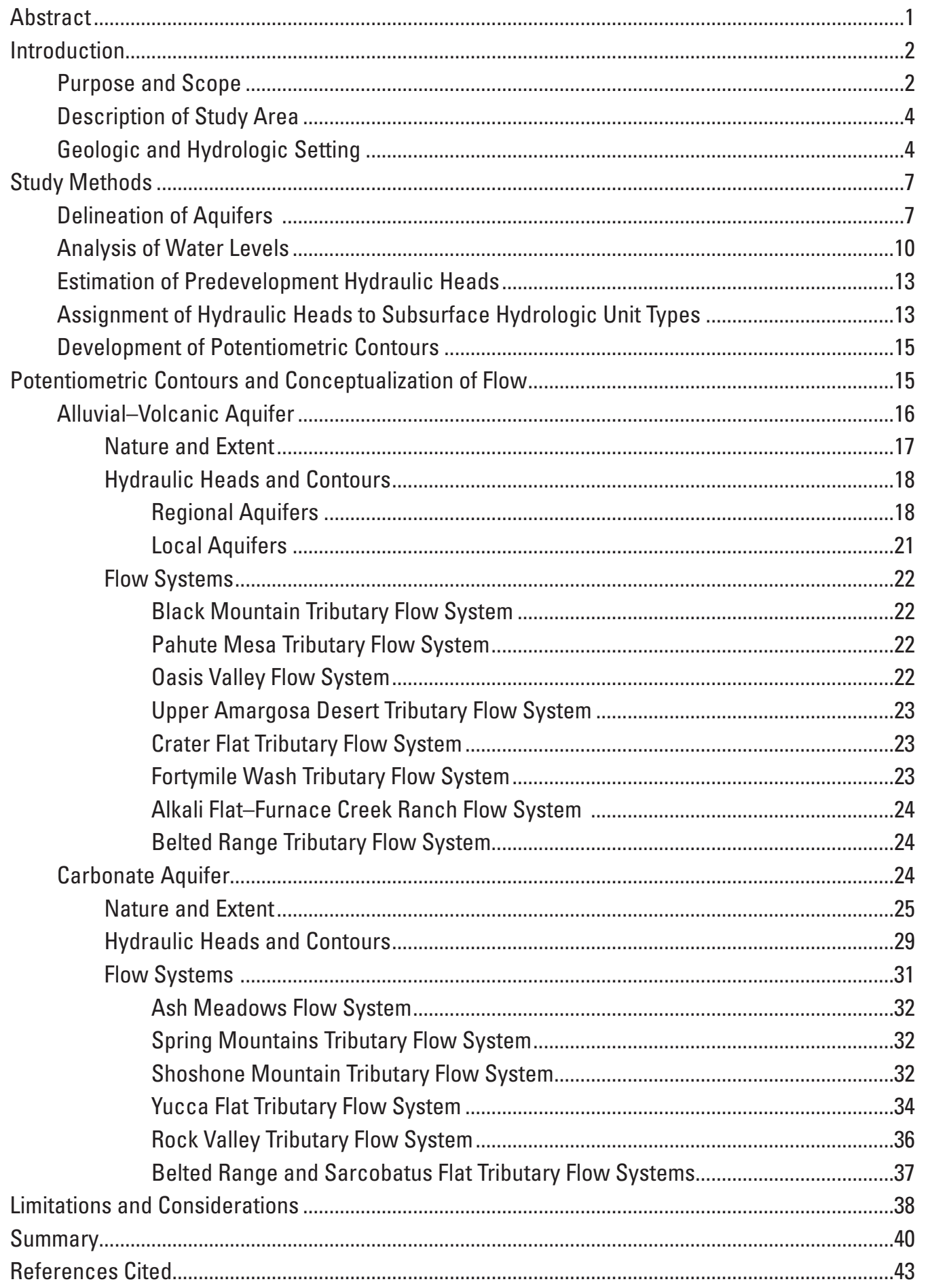




\section{Contents-Continued}

Appendix 1. Water Levels Measured in the Nevada Test Site Area, Nevada, 1941-2008.

Appendix 2. Mean Water Levels, Hydraulic Heads, Well Characteristics, and Selected

Water Temperatures for Wells Used to Develop Potentiometric Contours in the

Nevada Test Site Area.

Appendix 3. Hydrostratigraphic Units and Subsurface Hydrologic Unit Types for Wells in the Nevada Test Site Area, as Projected from Hydrostratigraphic Framework

Models.

\section{Plates}

Plate 1. Map showing location of boreholes with water-level measurments that were used to develop potentiometric contours in the Nevada Test Site area, Nevada.

Plate 2. Hydrogeologic sections showing distribution of subsurface hydrologic unit types and designations of local and regional aquifer and confining units in the Nevada Test Site area, Nevada.

Plate 3. Map showing predevelopment hydraulic heads and potentionmetric contours for the alluvial-volcanic aquifer in the Nevada Test Site area, Nevada.

Plate 4. Map showing predevelopment hydraulic heads and potentiometric contours for the carbonate aquifer in the Nevada Test Site area, Nevada.

Plate 5. Map showing groundwater flow systems of the regional alluvial-volcanic aquifer in the Nevada Test Site area, Nevada.

Plate 6. Map showing groundwater flow systems of the regional carbonate aquifer in the Nevada Test Site area, Nevada.

\section{Figures}

Figure 1. Map showing local geographic, hydrographic, and physiographic features of the Nevada Test Site region

Figure 2. Chart showing aquifer and confining unit classification system used to conceptualize groundwater flow in the Nevada Test Site area, Nevada

Figure 3. Chart showing correlation of subsurface hydrologic unit types (SHUT) and hydrostratigraphic units (HSU) for the Nevada Test Site area, Nevada

Figure 4. Example from appendix 1 Excel workbook showing water levels that were analyzed in well ER-12-4 main, Nevada Test Site area, Nevada

Figure 5. Example from appendix 3 Excel workbook showing hydrostratigraphic units and their relation to water level and open intervals in well ER-12-4 main,

Nevada Test Site area, Nevada

Figure 6. Generalized hydrogeologic cross sections for pre-Cenozoic rocks in the Nevada Test Site area, Nevada

Figure 7. Map showing major groundwater flow systems of the regional alluvial-volcanic and carbonate aquifers in the Nevada Test Site area, Nevada 


\section{Conversion Factors and Datums}

Conversion Factors

Inch/Pound to SI

\begin{tabular}{|c|c|c|}
\hline Multiply & By & To obtain \\
\hline \multicolumn{3}{|c|}{ Length } \\
\hline inch (in.) & 2.54 & centimeter (cm) \\
\hline foot (ft) & 0.3048 & meter $(\mathrm{m})$ \\
\hline mile (mi) & 1.609 & kilometer (km) \\
\hline \multicolumn{3}{|c|}{ Volume } \\
\hline acre-foot (acre-ft) & 1,233 & cubic meter $\left(\mathrm{m}^{3}\right)$ \\
\hline \multicolumn{3}{|c|}{ Flow rate } \\
\hline acre-foot per year (acre-ft/yr) & 0.06309 & cubic hectometer per year $\left(\mathrm{hm}^{3} / \mathrm{yr}\right)$ \\
\hline \multicolumn{3}{|c|}{ Density } \\
\hline pound per cubic foot $\left(\mathrm{lb} / \mathrm{ft}^{3}\right)$ & 16.02 & kilogram per cubic meter $\left(\mathrm{kg} / \mathrm{m}^{3}\right)$ \\
\hline \multicolumn{3}{|c|}{ Hydraulic gradient } \\
\hline foot per mile (ft/mi) & 0.1894 & meter per kilometer (m/km) \\
\hline
\end{tabular}

Temperature in degrees Celsius $\left({ }^{\circ} \mathrm{C}\right)$ may be converted to degrees Fahrenheit $\left({ }^{\circ} \mathrm{F}\right)$ as follows:

$$
{ }^{\circ} \mathrm{F}=\left(1.8 x^{\circ} \mathrm{C}\right)+32 .
$$

Temperature in degrees Fahrenheit $\left({ }^{\circ} \mathrm{F}\right)$ may be converted to degrees Celsius $\left({ }^{\circ} \mathrm{C}\right)$ as follows:

$$
{ }^{\circ} \mathrm{C}=\left({ }^{\circ} \mathrm{F}-32\right) / 1.8 \text {. }
$$

Datums

Vertical coordinate information is referenced to the National Geodetic Vertical Datum of 1929 (NGVD 29).

Horizontal coordinate information is referenced to the North American Datum of 1983 (NAD 83) unless otherwise stated.

Altitude, as used in this report, refers to distance above or below (-) the vertical datum. 
This page intentionally left blank. 


\title{
Groundwater Flow Systems at the Nevada Test Site, Nevada: A Synthesis of Potentiometric Contours, Hydrostratigraphy, and Geologic Structures
}

\author{
By Joseph M. Fenelon, Donald S. Sweetkind, and Randell J. Laczniak
}

\section{Abstract}

Contaminants introduced into the subsurface of the Nevada Test Site by underground nuclear testing are of concern to the U.S. Department of Energy and regulators responsible for protecting human health and safety. The potential for contaminant movement away from the underground test areas and into the accessible environment is greatest by groundwater transport. The primary hydrologic control on this transport is evaluated and examined through a series of contour maps developed to represent the hydraulichead distribution within each of the major aquifers underlying the area. Aquifers were identified and their extents delineated by merging and analyzing multiple hydrostratigraphic framework models developed by other investigators from existing geologic information. A map of the hydraulic-head distribution in each major aquifer was developed from a detailed evaluation and assessment of available water-level measurements. Multiple spreadsheets that accompany this report provide pertinent water-level and geologic data by well or drill hole.

Aquifers are mapped and discussed in general terms as being one of two types: alluvial-volcanic, or carbonate. Both aquifer types are subdivided and mapped as independent regional and local aquifers, based on the continuity of their component rock. Groundwater-flow directions, approximated from potentiometric contours that were developed from the hydraulic-head distribution, are indicated on the maps and discussed for each of the regional aquifers and for selected local aquifers. Hydraulic heads vary across the study area and are interpreted to range in altitude from greater than 5,000 feet in a regional alluvial-volcanic aquifer beneath a recharge area in the northern part of the study area to less than 2,300 feet in regional alluvial-volcanic and carbonate aquifers in the southwestern part of the study area. Flow directions throughout the study area are dominantly south-southwest with some local deviations. Vertical hydraulic gradients between aquifer types are downward throughout most of the study area; however, flow from the alluvial-volcanic aquifer into the underlying carbonate aquifer, where both aquifers are present, is believed to be minor because of an intervening confining unit. Limited exchange of water between aquifer types occurs by diffuse flow through the confining unit, by focused flow along fault planes, or by direct flow where the confining unit is locally absent.

Interflow between regional aquifers is evaluated and mapped to define major flow paths. These flow paths delineate tributary flow systems, which converge to form intermediate and regional flow systems. The implications of these flow systems in controlling transport of radionuclides away from the underground test areas at the Nevada Test Site are briefly discussed. Additionally, uncertainties in the delineation of aquifers, the development of potentiometric contours, and the identification of flow systems are identified and evaluated.

Eleven tributary flow systems and three larger flow systems are mapped in the Nevada Test Site area. Flow systems within the alluvial-volcanic aquifer dominate the western half of the study area, whereas flow systems within the carbonate aquifer are most prevalent in the southeastern half of the study area. Most of the flow in the regional alluvial-volcanic aquifer that moves through the underground testing area on Pahute Mesa is discharged to the land surface at springs and seeps in Oasis Valley. Flow in the regional carbonate aquifer is internally compartmentalized by major geologic structures, primarily thrust faults, which constrain flow into separate corridors. Contaminants that reach the regional carbonate aquifer from testing areas in Yucca and Frenchman Flats flow toward downgradient discharge areas through the Alkali Flat-Furnace Creek Ranch or Ash Meadows flow systems and their tributaries. 


\section{Introduction}

The potential for subsurface transport of radionuclides and other underground nuclear test-generated contaminants at the Nevada Test Site (NTS) is of concern and interest to the U.S. Department of Energy and to other regulatory Federal and State agencies. Currently, numerical models are being developed to simulate the flow of groundwater and the transport of contaminants away from areas historically used to test nuclear devices underground (U.S. Department of Energy, 1999a; 1999b; 2000a; 2004). As part of this effort, numerous wells have been drilled and a number of geologic studies have been completed to better characterize the geology and hydrology of the subsurface environment. Geologic data obtained from these and other wells, and insights gained from these investigations, have been integrated spatially to create three-dimensional hydrostratigraphic framework models (HFM) of the local and regional hydrostratigraphy (Bechtel Nevada, 2002, 2005, 2006; Faunt, Sweetkind, and Belcher, 2004; National Security Technologies, LLC, 2007). These HFMs portray the groundwater flow system as a complex series of aquifers separated by confining units. Flow and transport models founded on these geologic frameworks are being used to simulate near- and far-field transport of contaminants introduced into the groundwater flow system by underground testing and to formulate decisions regarding the management of these contaminants.

The direction and rate of subsurface transport away from former underground testing areas is controlled, in part, by the hydraulic-head gradient. The difference in hydraulic head across a given area defines the gradient and describes the groundwater flow potential. Hydraulic head commonly is equated to water-level altitude, and at a well, commonly is estimated by subtracting a depth-to-water measurement from the land-surface altitude. The spatial distribution of hydraulic heads throughout the NTS region typically has been conveyed on maps by a single set of generalized potentiometric contours. Most of these maps are regional in scope (Fenske and Carnahan, 1975; Waddell and others, 1984; Laczniak and others, 1996; D’Agnese and others, 1998; Harrill and Bedinger, 2004), although others are focused on distinct areas (fig. 1) such as Pahute Mesa (Blankennagel and Weir, 1973; O'Hagan and Laczniak, 1996), Yucca Mountain (Robison, 1984; Ervin and others, 1994; Tucci and Burkhardt, 1995), or Yucca Flat (Doty and Thordarson, 1983; Hale and others, 1995). Potentiometric surfaces based on a multiple-aquifer concept are few and include a regional-scale map of the NTS area that contours hydraulic heads in rocks of Cenozoic and pre-Tertiary age (Winograd and Thordarson, 1975), and maps of the Rainier Mesa and Shoshone Mountain area that contour heads in a volcanic aquifer and in local and regional carbonate aquifers (Fenelon and others, 2008).
Maps that portray the hydraulic-head distribution in large geologically complex areas as a single set of contours must discount vertical flow components, and generalize the subsurface geology as one continuous, regionally extensive flow system. In actuality, as is indicated by published hydrostratigraphic framework models, the groundwater flow system is made up of multiple aquifers hydraulically separated by confining units. The degree of hydraulic separation depends on the properties of the intervening confining rock. Hydraulic separation of these aquifers at the NTS creates multiple, semi-independent flow systems, in which the direction and rate of groundwater flow is unique to each aquifer and is controlled largely by the head gradients within them. Successful simulation and accurate forecasts of the potential for radionuclide transport requires an understanding of the flow direction and rate within the individual aquifers, particularly in the aquifer or aquifers that contain or are susceptible to test-generated contaminants. One way of advancing this understanding is through an analysis of water levels that thoroughly integrates both old and new geologic and hydrologic information to develop potentiometric contours that define hydraulic gradients in the major aquifers of the area. A study by the U.S. Geological Survey (USGS), in cooperation with the U. S. Department of Energy, was undertaken to complete this analysis.

\section{Purpose and Scope}

The purpose of this report is to delineate the major aquifers beneath the NTS area and to define and describe the likely direction of groundwater flow in each of these aquifers under predevelopment conditions. Predevelopment conditions assume equilibrium or a near equilibrium state in the groundwater flow system prior to any major changes prompted by human intervention, such as pumping and nuclear testing. Groundwater flow directions are determined by constructing potentiometric surface maps that are designed to conceptualize and describe flow within and between the major aquifers in the multi-aquifer flow system of the NTS area. Maps and their component hydraulic heads can be used as calibration targets for flow models and can help identify likely groundwater flow paths.

Maps are developed to delineate the spatial extent of the major aquifers throughout the NTS and surrounding area and to convey the primary direction of flow within each aquifer. These maps also show areas of recharge and likely areas of lateral leakage into and out of each aquifer. A second set of maps delineates flow systems and tributary flow systems for the regional aquifers. 


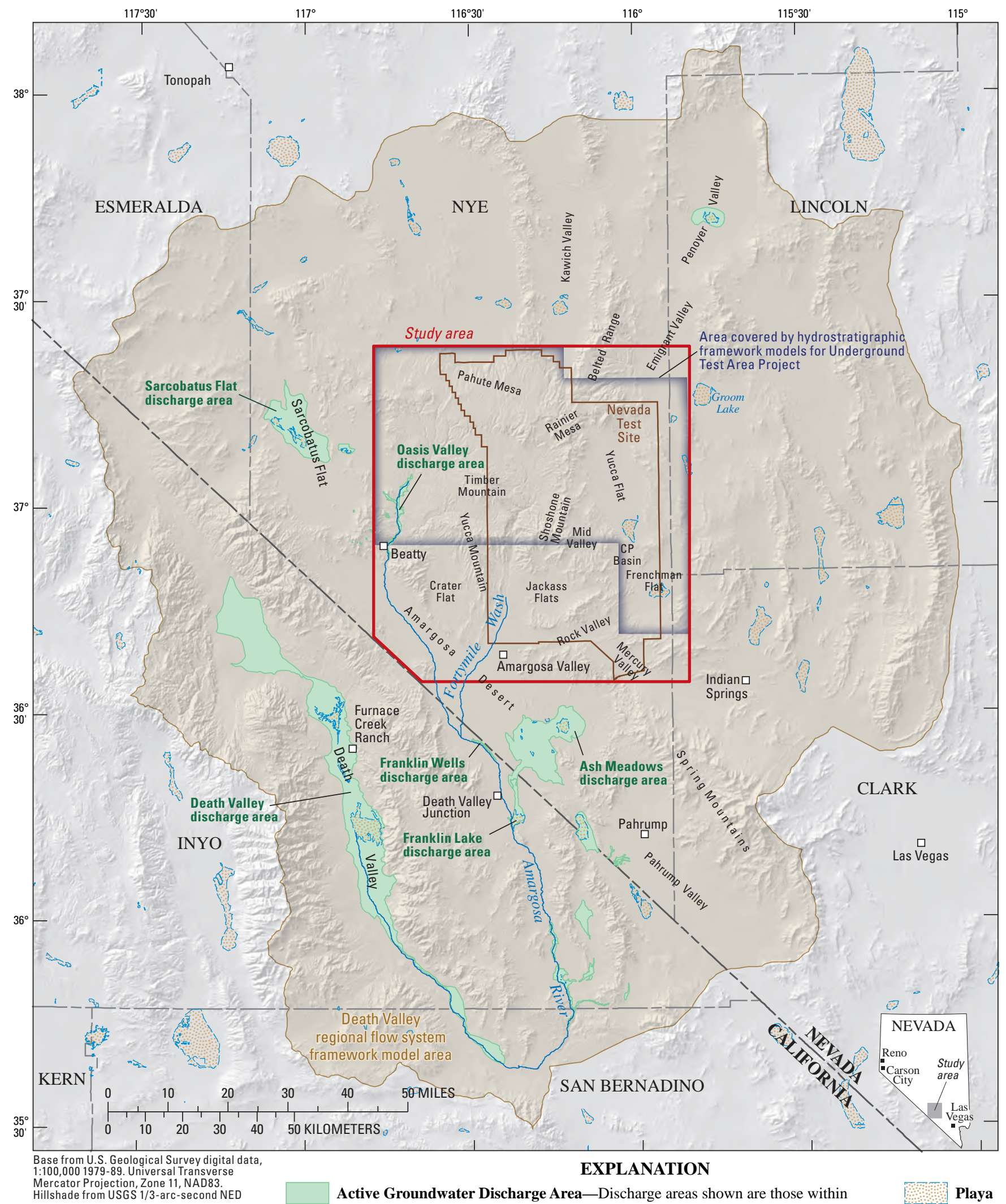

the Death Valley groundwater flow system. Discharge areas labeled are those directly downgradient of the Nevada Test Site.

Figure 1. Local geographic, hydrographic, and physiographic features of the Nevada Test Site region. 
The report summarizes well-construction and water-level data acquired from about 800 wells that were used to develop potentiometric contours. The aquifers and confining units associated with the open interval or intervals of a specific well are based on hydrostratigraphic interpretations published in three-dimensional framework models that detail the hydrogeology of the study area (Bechtel Nevada, 2002, 2005, 2006; Faunt, Sweetkind, and Belcher, 2004; National Security Technologies, LLC, 2007). Hydrostratigraphic interpretations and well-construction and water-level data associated with a well can be displayed using interactive spreadsheets included as appendixes in the report.

\section{Description of Study Area}

The study area is about $90 \mathrm{mi}$ northwest of Las Vegas, Nevada, and includes the NTS and surrounding area (ig. 1). The topography of the study area is highly variable and is controlled by a diverse physiography marked by many intermontane features. These features include an extensive volcanic plateau (Pahute Mesa, Rainier Mesa, and Timber Mountain) that covers most of the northwestern part of the NTS and several elongated valleys (such as Yucca Flat, Rock Valley, and Amargosa Desert) that extend across the eastern and southern parts of the NTS. The study area spans two major North American deserts-the Great Basin, generally denoted by the higher plateau region; and the Mojave Desert, which includes the remaining low-lying area. Altitudes generally are lowest in the south and highest in the north, and range from about 2,400 ft in Amargosa Desert to about 7,800 ft in the Belted Range (fig 1).

The climate of the study area is arid to semiarid, characteristic of a high desert region. The climate is characterized by hot summers and mild winters, large fluctuations in daily and annual temperatures, low precipitation and humidity, and occasional high winds. Average summertime maximum temperatures across the study area range from greater than 100 to $80^{\circ} \mathrm{F}$, and average wintertime minimum temperatures range from 37 to $22^{\circ} \mathrm{F}$ (Soulé, 2006). Temperatures generally are 10 to $20^{\circ} \mathrm{F}$ cooler in the highland areas, and can fluctuate by more than $30^{\circ} \mathrm{F}$ over a single day. Annual precipitation ranges from less than 5 in. on the lowest valley floors to nearly 13 in. on Rainier Mesa and the highest mountain crests (Soulé, 2006). Precipitation occurs primarily in late autumn through early spring and in mid-summer. Precipitation falls primarily as rain, and during the winter months as snow, at high altitudes and in the northernmost regions. Streams in the study area are ephemeral and flow only for brief periods after infrequent intense rainfall and during and shortly after spring snowmelt. Channeled perennial flow in the study area occurs only over short reaches downgradient of a few large springs in the Oasis Valley area north of Beatty, Nev. (fig. 1). The limited runoff generally is conveyed from upland to lowland areas through washes that normally are dry. Shallow ponding occasionally occurs during spring in the playas of Yucca and Frenchman Flats.

The NTS was operated as the primary continental location for testing nuclear devices between 1951 and 1992. Since 1961, all nuclear devices tested have been detonated underground. At the NTS, 828 underground tests were conducted; 62 of these tests included multiple simultaneous detonations (U.S. Department of Energy, 2000b). Underground detonations at the NTS totaled 921, and with only a few exceptions, were tested in Yucca and Frenchman Flats, on Rainier and Pahute Mesas, and at Shoshone Mountain (fig. 1). At Yucca Flat, Frenchman Flat, and Pahute Mesa, all underground tests were conducted in vertical shafts drilled into alluvial and volcanic rock, and in a few cases into carbonate and granitic rock; whereas, at Rainier Mesa and Shoshone Mountain nearly all tests were conducted in tunnel complexes mined into low-permeability, zeolitized tuff.

In more than one-third of the underground tests at the NTS, nuclear devices were detonated near or below the water table, principally in Pahute Mesa, Yucca Flat, and Frenchman Flat (U.S. Department of Energy, 1997b). At Pahute Mesa, more than 90 percent of the devices tested were detonated at or below the water table (Laczniak and others, 1996). Tests below the regional water table typically were larger in explosive yield and detonated in deeper vertical shafts to prevent releases of radionuclide-laden gasses into the atmosphere. Conversely, all devices tested at Rainier Mesa and Shoshone Mountain were of smaller yield and detonated above the water table in unsaturated or partially saturated rock.

\section{Geologic and Hydrologic Setting}

The geology of the NTS and surrounding area is stratigraphically and structurally complex and includes a locally thick Cenozoic volcanic and sedimentary section that unconformably overlies previously deformed rocks of Proterozoic through Paleozoic age. Pre-Cenozoic rocks crop out in the eastern one-third of the study area and locally in areas south of the NTS, but in the western two-thirds of the study area, these rocks are largely buried by Cenozoic sediment and volcanic rock. The pre-Cenozoic section includes, from oldest to youngest: (1) up to 9,000 ft of Late Proterozoic and Lower Cambrian siliceous and argillaceous metasediments (Stewart, 1970; 1972); (2) up to $15,000 \mathrm{ft}$ of Middle Cambrian through Devonian dolomite, interbedded limestone, and thin but persistent shale and quartzite layers (Stewart and Poole, 1974; Poole and others, 1992); (3) about 4,000 ft of Mississippian siliceous siltstone, sandstone, and conglomerate (Poole and Sandberg, 1977; Trexler and others, 1996); (4) a relatively thin Pennsylvanian limestone that locally overlies the Mississippian siliciclastic section; and (5) local granitic intrusive bodies. The Cenozoic section 
includes local accumulations of Oligocene to Early Miocene dominantly lacustrine sediments, Miocene volcanic rocks that range from regionally distributed rhyolitic ash-flow sheets to more local rhyolitic lava flows (Byers, Carr, Orkild, and others, 1976; Sawyer and others, 1994), and post-Miocene alluvial basin fill and local basalts.

The NTS and surrounding area was affected by two opposing styles of tectonic deformation: mid-Mesozoic through Eocene compressive deformation, and a subsequent phase of mid-to-late Cenozoic extension. The pre-Cenozoic section was affected by south- and southeast-directed shortening in the form of regional thrust faults and more localized folds (Cole and Cashman, 1999; Snow and Wernicke, 2000). Cenozoic deformation resulted in the formation of a diverse assemblage of structures, including high and low-angle normal faults, northwest- and northeaststriking strike-slip faults, and Miocene caldera collapse structures (Carr, 1984; Workman and others, 2002). The combination of normal, reverse, and strike-slip faulting and folding episodes and caldera formation has resulted in the juxtaposition of diverse rock types, creating a highly variable and complex subsurface geology and hydrology.

The mapped geologic units at the NTS and surrounding area have been grouped as hydrostratigraphic units (HSUs) on the basis of similar geologic and hydraulic properties (Winograd and Thordarson, 1975; Laczniak and others, 1996; Bechtel Nevada, 2002, 2005, 2006; Faunt, Sweetkind, and others, 2004; National Security Technologies, LLC, 2007). Three general groupings of the most permeable HSUs have been classified as aquifers: basin-fill alluvial deposits, volcanic rocks consisting of welded tuffs and lava flows, and fractured carbonate rocks (fig. 2). The principal carbonate-rock aquifer consists of the thick sequence of Paleozoic carbonate rock that extends throughout much of the subsurface of central and southeastern Nevada (Dettinger and others, 1995; Harrill and Prudic, 1998) and crops out in the eastern one-third of the study area. Fractured Cenozoic volcanic rock and permeable Cenozoic basin-fill alluvium form important regional and local aquifers that often contribute flow to the underlying Paleozoic carbonate-rock aquifer (Blankennagel and Weir, 1973; Winograd and Thordarson, 1975; Harrill and others, 1988; Dettinger and others, 1995). Groundwater flow at the NTS and surrounding area is obstructed or diverted by low-permeability rock that forms confining units. Rock types that form confining units include siliciclastic rock, granitic rock, bedded and nonwelded volcanic tuffs, and fine-grained alluvial sediment (fig. 2). Proterozoic to Early Cambrian metamorphic and siliciclastic rocks and Paleozoic siliciclastic rock form a basement confining unit, whereas the zeolitically altered and nonwelded tuffs within the Cenozoic volcanic section and fine-grained parts of the Cenozoic basin fill form important local confining units (Blankennagel and Weir, 1973; Winograd and Thordarson, 1975). Certain Cenozoic volcanic rock sequences are difficult to classify either as an aquifer or a confining unit because of their heterogeneity and are referred to in this report and other referenced hydrostratigraphic framework reports as volcanic composite unit (fig. 2).

Depending on their extent and degree of interconnection, aquifers can form regional or local flow systems. As will be shown in this report, widespread interconnected aquifers make up regional flow systems in which groundwater moves, nearly unimpeded, over long distances. Poorly connected, less extensive aquifers make up isolated to semi-isolated local flow systems that commonly provide a source of diffuse leakage or local drainage to an adjacent or underlying regional flow system. Diffuse leakage usually occurs over a widespread area at a low rate and most often is associated with leakage across an intervening confining unit. Local drainage usually occurs at a higher rate over a limited area and most often is associated with flow through a permeable fault zone or along/through the zone of contact between a local aquifer and a regional aquifer.

Most of the groundwater flowing beneath the NTS and surrounding area originates as precipitation falling in highland areas. On the NTS, water recharges the groundwater flow system locally in highland areas such as eastern Pahute Mesa, Rainier Mesa, Timber Mountain, and Shoshone Mountain, and along the Belted Range (pl. 3). Some water flowing beneath the southeastern part of the study area originates from precipitation falling on the Spring Mountains (fig. 1). The other major source of recharge is precipitation falling on upland and mountainous areas north and east of the study area in central Nevada. Recharge occurs as some of the precipitation falling on these highland areas collects in surface fractures and openings and infiltrates downward by way of interconnected fractures or through the rock matrix to depths beyond the influence of active evaporation and transpiration. The presence of less-permeable rock commonly impedes the downward movement of water, thereby creating zones of locally perched and semi-perched groundwater (Thordarson, 1965; Blankennagel and Weir, 1973). The term "semiperched" is used to differentiate zones of shallow, elevated water that are underlain by saturated rocks; perched zones, by definition, are underlain by unsaturated rocks (Meinzer, 1923). The few springs present at high altitude in the study area have very low flow and are supported by perched and semi-perched water that moves laterally until discharging at land surface (Winograd and Thordarson, 1975).

The recognition and delineation of a regional saturated zone beneath the upland recharge areas at the NTS is complicated by the presence of locally perched and semiperched groundwater. Recharge to upland areas like eastern Pahute Mesa and Rainier Mesa has created groundwater mounds that locally influence the groundwater flow direction in perched and semi-perched zones and in underlying saturated flow systems. Water within unsaturated rock or in semi-perched and perched zones beneath the underground 


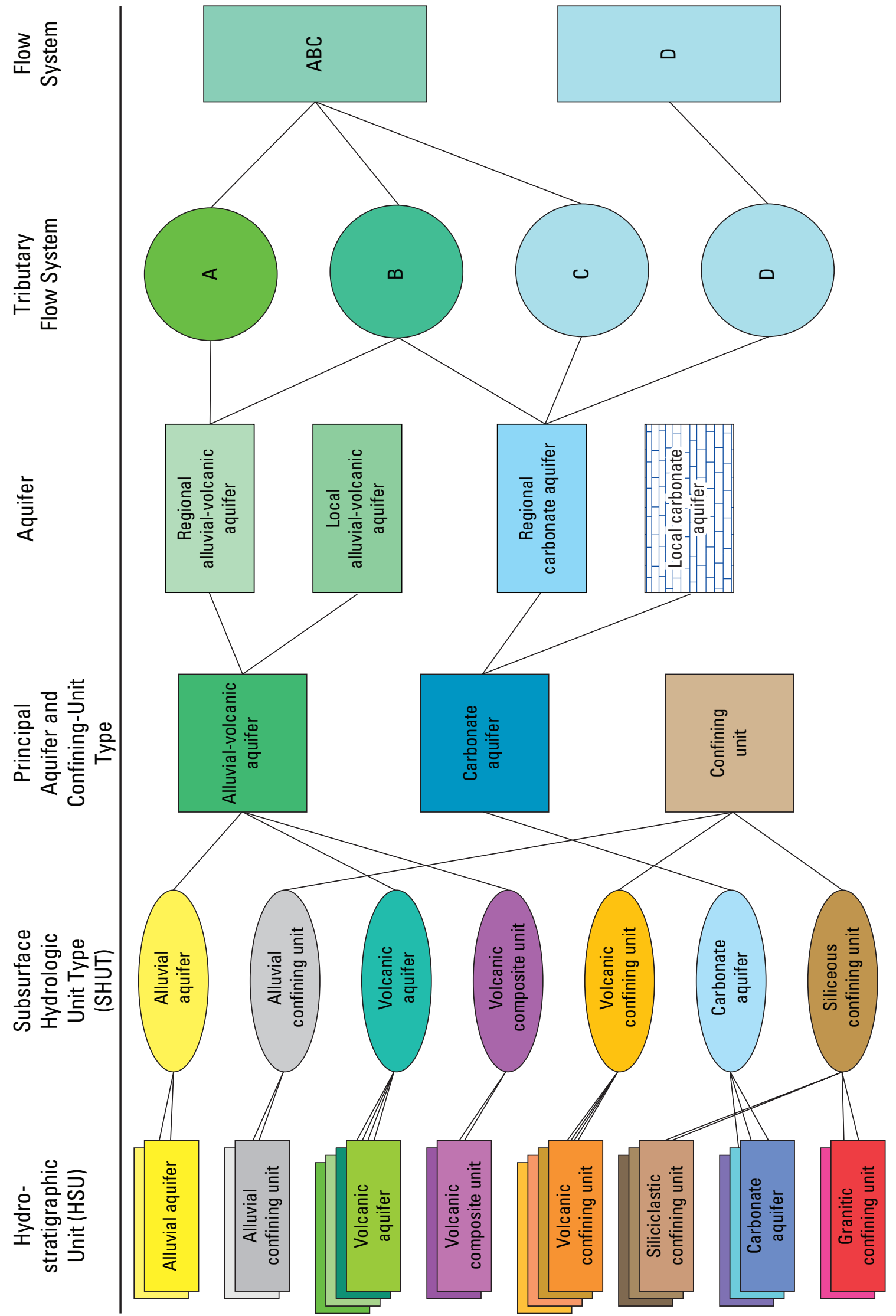

Figure 2. Aquifer and confining unit classification system used to conceptualize groundwater flow in the Nevada Test Site area, Nevada. 
test areas may move test-generated contaminants downward into saturated, permeable rock. Once within saturated rock, transport of the contaminants is controlled by the rate and direction of groundwater flow, which itself is controlled by the permeability of the host rock and by differences in hydraulic head.

Groundwater within the regional flow systems generally moves toward discharge areas south, southwest, and west of the NTS. Groundwater discharges from springs or by diffuse upward flow into an overlying shallow flow system where the water is evaporated, or transpired by phreatophytes. Major areas of groundwater discharge from the study area (fig. 1) are Oasis Valley, Ash Meadows, Franklin Lake, Sarcobatus Flat, and Death Valley; a small component of flow in the northern part of the study area may discharge to Penoyer Valley (Winograd and Thordarson, 1975; Laczniak and others, 1996).

Some groundwater within the NTS has been removed from the underlying aquifers by the pumping of wells. Local pumping at the NTS began in 1951, and through 2008, the amount of water removed totals about 77,000 acre-ft (U.S. Geological Survey, 2009). Most water on the NTS has been pumped from wells completed in 16 boreholes (pl. 1). The water was used almost exclusively for local water supply in support of various NTS operations. A small portion of the water withdrawn has been used solely for investigative purposes. Some groundwater also has been pumped from within the study area from wells completed in boreholes south and southwest of the NTS (pl. 1) including withdrawals for rural-community water supply, from wells near Beatty, Nev.; for mining, from wells in Crater Flat; and for irrigation, from wells in the southern part of Amargosa Desert (pl. 1).

\section{Study Methods}

The general approach used to develop a conceptualization of groundwater flow through the study area was to delineate the extent of the permeable rocks forming the two primary aquifer types_-alluvial-volcanic and carbonate (fig. 2). Discrete aquifers identified within each of these aquifer types are classified as either regional or local. Regional aquifers typically include large, spatially extensive blocks of permeable rock that together form part of a larger flow system, whereas local aquifers typically are areally less extensive, hydraulically isolated, and drain only to adjacent confining units. Hydraulic heads in each of the regional aquifers delineated in the study area are contoured to determine general flow directions and their interconnection with other regional aquifers and adjacent confining units.

\footnotetext{
${ }^{1}$ The units in the Death Valley regional flow system HFM are called "hydrogeologic units" in Faunt, Sweetkind, and Belcher (2004). To be consistent with discussions in this report, these units will be referred to as hydrostratigraphic units.
}

\section{Delineation of Aquifers}

The first step in the flow conceptualization process was to identify and delineate the regional and local aquifers in the NTS and surrounding area. These aquifers were identified and mapped using a composite hydrostratigraphic framework developed by merging five previously constructed threedimensional hydrostratigraphic framework models (HFMs). Four of these models were constructed as part of the U.S. Department of Energy's Underground Test Area Project (fig. 1). The models support investigations of radionuclide contamination in the Pahute Mesa, Rainier Mesa-Shoshone Mountain, Yucca Flat-Climax Mine, and Frenchman Flat areas (Bechtel Nevada, 2002, 2005, 2006; National Security Technologies, LLC, 2007). The fifth HFM was constructed as part of a U.S. Geological Survey study to model the Death Valley regional flow system (Faunt, Sweetkind, and Belcher, 2004) and is inclusive of the entire study area (fig. 1). This more regionally extensive framework was used to delineate aquifers only in parts of the study area not covered by the other more local and detailed framework models.

Each HFM is composed of hydrostratigraphic units ${ }^{1}$ (HSU) that consist of one or more stratigraphic units with similar geologic and hydraulic properties. The 110 HSUs identified in the five HFMs (fig. 3) form the hydrogeologic foundation used to develop the conceptualization of groundwater flow presented in this report. The HSUs evaluated as part of this study include 51 aquifers, 45 confining units, and 14 composite units (a combination of aquifer and confining unit).

Framework HSUs were grouped into generalized unit types on the basis of rock type and whether the HSU was classified as an aquifer, composite unit, or confining unit (fig. 2). The combining of HSUs reduced the number of subsurface units to seven (iggs. 2 and $\underline{3}$ ). These seven units herein are referred to as subsurface hydrologic unit types, or SHUTs, and include:

- alluvial aquifer,

- alluvial confining unit,

- volcanic aquifer,

- volcanic composite unit,

- volcanic confining unit,

- carbonate aquifer, and

- siliceous confining unit. 
HSU Name

Younger alluvial aquifer

Alluvial aquifer

Alluvial aquifer 3

Playa confining unit 2

Playa confining unit

Older altered alluvial aquifer

Alluvial aquifer 2

Basalt lava flow aquifer

Lava flow unit

Older altered alluvial aquifer 1

Playa confining unit 1 upper

Alluvial aquifer 1

Playa confining unit 1 lower

Younger alluvial confining unit

Older alluvial aquifer

Older alluvial confining unit

Limestone aquifer

Younger volcanic-rock unit

Volcanic- and sedimentary-rock unit (upper)

Volcanic sedimentary-rock unit (lower)

Younger volcanic composite unit

Thirsty Canyon volcanic aquifer

Detached volcanic aquifer

Detached volcanic composite unit

Fortymile Canyon composite unit

Fortymile Canyon aquifer

Timber Mountain upper vitric-tuff aquifer

Timber Mountain welded-tuff aquifer

Timber Mountain lower vitric-tuff aquifer

Thirsty Canyon-Timber Mountain volcanic-rock unit

Timber Mountain composite unit

Timber Mountain composite unit 2

Tannenbaum Hill lava flow aquifer

Tannenbaum Hill composite unit

Timber Mountain aquifer

Subcaldera volcanic confining unit

Fluorspar Canyon confining unit

Rainier Mesa breccia confining unit

Windy Wash aquifer

Paintbrush composite unit

Paintbrush vitric-tuff aquifer

Upper tuff confining unit

Benham aquifer

Upper Paintbrush confining unit

Tiva Canyon aquifer

Paintbrush lava flow aquifer

Lower Paintbrush confining unit

Paintbrush volcanic-rock aquifer

Topopah Spring aquifer

Lower vitric-tuff aquifer

Calico Hills volcanic-rock unit

Yucca Mountain/Calico Hills lava-flow aquifer

Yucca Mountain/Crater Flat composite unit

Calico Hills vitric-tuff aquifer

Calico Hills vitric tuff composite unit
HSU

SHUT

SHUT Name

Notes

\begin{tabular}{|c|c|c|c|}
\hline YAA & \multirow{3}{*}{ AA0 } & \multirow{3}{*}{ Alluvial aquifer ${ }^{1}$} & \multirow{4}{*}{$\begin{array}{l}\text { SHUT = Subsurface hydrologic unit } \\
\text { type }\end{array}$} \\
\hline AA & & & \\
\hline AA3 & & & \\
\hline PCU2T & \multirow{2}{*}{ ACU } & \multirow{2}{*}{ Alluvial confining unit 2} & \\
\hline PCUT & & & HSU = Hydrostratigraphic unit \\
\hline OAA & \multirow{5}{*}{ AAO } & \multirow{5}{*}{ Alluvial aquifer ${ }^{1}$} & \multirow{7}{*}{$\begin{array}{l}1 \text { The alluvial aquifer is dominated } \\
\text { by alluvium, but includes colluvium, } \\
\text { eolian sands, and minor basin- } \\
\text { filling deposits such as playa } \\
\text { sediments, freshwater limestones, } \\
\text { and thin lava flows that are } \\
\text { interspersed with alluvium. }\end{array}$} \\
\hline AA2 & & & \\
\hline BLFA & & & \\
\hline LFU & & & \\
\hline OAA1 & & & \\
\hline PCU1U & ACU & \multirow{2}{*}{$\begin{array}{l}\text { Alluvial confining unit } 2 \\
\text { Alluvial aquifer }{ }^{2}\end{array}$} & \\
\hline AA1 & AAO & & \\
\hline PCU1L & \multirow{2}{*}{ ACU } & \multirow{7}{*}{$\begin{array}{l}\text { Alluvial confining unit } 2 \\
\text { Alluvial aquifer }{ }^{1} \\
\text { Alluvial confining unit } 2 \\
\text { Alluvial aquifer }{ }^{1} \\
\text { Alluvial confining unit } 2 \\
\text { Alluvial aquifer }{ }^{1}\end{array}$} & \multirow{7}{*}{$\begin{array}{l}2 \text { The alluvial confining unit includes } \\
\text { a complex interfingering of basin-fill } \\
\text { lithologies such as nonwelded tuffs, } \\
\text { and fluvial, spring-deposit, and } \\
\text { lacustrine sediments. Sedimentary } \\
\text { rocks rich in volcanic ash in the } \\
\text { Amargosa Desert are included in } \\
\text { this unit. }\end{array}$} \\
\hline YACU & & & \\
\hline OAA & AAO & & \\
\hline OACU & ACU & & \\
\hline $\mathrm{LA}$ & $\mathrm{AAO}$ & & \\
\hline YVU & ACU & & \\
\hline VSU_up & AAO & & \\
\hline
\end{tabular}

\begin{tabular}{l|l} 
VSU_low & ACU \\
\cline { 1 - 1 } Alluvial confining unit
\end{tabular}

Volcanic composite unit

Volcanic aquifer

Volcanic composite unit

Volcanic aquifer

Volcanic composite unit

Volcanic aquifer

Volcanic composite unit

Volcanic aquifer

Volcanic confining unit

Volcanic aquifer

Volcanic composite unit

Volcanic aquifer

Volcanic confining unit

Volcanic aquifer

Volcanic confining unit

Volcanic aquifer

Volcanic confining unit

Volcanic aquifer

Volcanic composite unit

Volcanic aquifer

Volcanic composite unit

Volcanic aquifer

Volcanic composite unit

Figure 3. Correlation of subsurface hydrologic unit types (SHUT) and hydrostratigraphic units (HSU) for the Nevada Test Site area, Nevada. For more information on these units, see worksheet “SHUTtoHSU_Chart" in appendix 3. 
HSU Name

Calico Hills zeolitic composite unit

Upper tuff confining unit 2

Calico Hills confining unit

Wahmonie confining unit

Wahmonie volcanic-rock unit

Inlet aquifer

Crater Flat composite unit

Crater Flat confining unit

Crater Flat-Prow Pass aquifer

Kearsarge aquifer

Stockade Wash welded-tuff aquifer

Lower vitric-tuff aquifer 2

Bullfrog confining unit

Upper tuff confining unit 1

Crater Flat-Bullfrog confining unit

Crater Flat-Tram aquifer

Belted Range aquifer

Lower vitric-tuff aquifer 1

Belted Range confining unit

Belted Range unit

Lower tuff confining unit

Pre-Grouse Canyon tuff lava flow aquifer

Tub Spring aquifer

Pre-Grouse Canyon tuff lava flow aquifer 1

Oak Spring Butte confining unit

Redrock Valley welded-tuff aquifer

Redrock Valley breccia confining unit

Lower tuff confining unit 1

Pre-Belted Range composite unit

Argillic tuff confining unit

Older volcanic-rock unit

Volcaniclastic confining unit

Ammonia Tanks intrusive confining unit

Redrock Valley intrusive confining unit

Rainier Mesa intrusive confining unit

Calico Hills intrusive confining unit

Calico Hills intrusive confining unit

Silent Canyon intrusive confining unit

Mesozoic granite confining unit

Black Mountain intrusive confining unit

Claim Canyon intrusive confining unit

Intrusive-rock confining unit

Crystalline-rock confining unit

Upper carbonate aquifer

Upper clastic confining unit 1

Upper clastic confining unit

Lower carbonate aquifer thrust plate

Lower carbonate aquifer thrust plate

Lower carbonate-rock aquifer thrust

Lower carbonate aquifer thrust plate 1

Lower clastic confining unit thrust plate 1

Lower clastic confining unit thrust plate 2

Lower clastic-rock confining unit thrust

Lower carbonate aquifer

Lower clastic confining unit
HSU SHUT $\quad$ SHUT Name

\begin{tabular}{|c|c|c|}
\hline$\overline{\mathrm{CHZCM}}$ & $\overline{\mathrm{VCM}}$ & Volcanic composite un \\
\hline UTCU2 & \multirow{4}{*}{ VCU } & \multirow{4}{*}{ Volcanic confining un } \\
\hline $\mathrm{CHCU}$ & & \\
\hline WCU & & \\
\hline WVU & & \\
\hline IA & VAO & Volcanic aquifer \\
\hline CFCM & VCM & Volcanic composite \\
\hline
\end{tabular}

CFCU

CFPPA

KA

SWA

LVTA2

BFCU

UTCU1

CFBCU

CFTA

BRA

LVTA1

BRCU

BRU

LTCU

PRETBG

TUBA

PRETBG_1

OSBCU

RVA

RVBCU

LTCU1

PBRCM

ATCU

OVU

VCU

ATICU

RVICU

RMICU

CHICU

TPGCH

SCICU

MGCU

BMICU

CCICU

ICU

XCU

UCA

UCCU1

UCCU

LCA3

LCA3a

LCA_t1

LCA3_1

LCCU1

LCCU2

LCCU_t1

LCA

LCCU
Volcanic confining unit

Volcanic aquifer

Volcanic confining unit

Volcanic aquifer

Volcanic confining unit

Volcanic aquifer

Volcanic confining unit

Volcanic aquifer

Volcanic confining unit

Volcanic aquifer

Volcanic confining unit

Volcanic composite unit

Volcanic confining unit

Volcanic composite unit

Siliceous confining unit

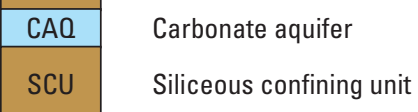

CAO

Carbonate aquifer

Siliceous confining unit

Carbonate aquifer

Siliceous confining unit

Figure 3. Correlation of subsurface hydrologic unit types (SHUT) and hydrostratigraphic units (HSU) for the Nevada Test Site area, Nevada.-Continued 
A three-dimensional configuration of these SHUTs was developed by constructing and evaluating hydrogeologic cross sections (pl. 2) and horizontal slices through the HFMs. On the basis of this evaluation, similar interconnected SHUTs were combined to form the principal aquifer- and confiningunit types of the NTS and surrounding area. Two principal aquifer types, referred to as the alluvial-volcanic aquifer and the carbonate aquifer, and one confining unit type, referred to simply as confining unit, were identified by this process (fig. 2). The alluvial-volcanic aquifer includes the alluvial aquifer, volcanic aquifer, and volcanic composite unit SHUTs. The confining unit is an undifferentiated grouping of all confining unit SHUTs. This grouping of the confining units was done to simplify the hydrogeologic framework, with the assumption that the single most important characteristic of each confining unit SHUT was not lithologic, but hydrologic - specifically the capacity of these rocks to impede groundwater flow. Only the regionally saturated part of each aquifer type was mapped and contoured. Areas underlain solely by a confining unit or areas dominated only by shallow aquifers with perched or semi-perched water were not specifically delineated or contoured as part of this study.

\section{Analysis of Water Levels}

In addition to determining the distribution of aquifers and confining units in the study area, water levels from 1,108 discrete open intervals in 648 boreholes (appendix 1) were compiled, reviewed, and analyzed. These boreholes are located in the study area or within a several-mile wide buffer zone surrounding the study area (appendix 1). Most of these boreholes are concentrated in areas of past underground testing on the NTS (Pahute Mesa, Rainier Mesa, Yucca Flat, and Frenchman Flat) and in the southwestern part of the study area near Yucca Mountain, Beatty, and the Amargosa Desert (pl. 1). As used in this report, a well represents a single temporary or permanent completion in a borehole, where each completion defines a unique set of open intervals. By this definition, many boreholes in the study area contain multiwell completions. Examples of a multi-well borehole are completions in which measurements are made in temporary packed intervals or where multiple monitoring tubes are installed within the annulus of a main well completion. Multi-well boreholes provide information on the changes in hydraulic head with depth. Naming conventions for the wells and boreholes referred to in this report are as follows. A well that is the sole completion interval in a borehole is assigned the name of the borehole. In boreholes with multiple completions, well names typically are differentiated from each other by a parenthetical expression added after the borehole name-for example: UE -12t 6 (1378 ft). A single number in the parenthetical expression refers to the depth of the well; two numbers separated by a dash refer to the depth of the top and bottom of the open interval in the well. In some cases, a well name consists of the borehole name and one of three non-parenthetical expressions (main, piezometer, or WW) that follow the borehole name. All well and borehole names in this report are derived from the USGS National Water Information System (NWIS) database and are italicized in the text for clarity. Official NTS hole names are provided in appendix 2.

Approximately 34,000 water levels were measured from 1941 to 2008 in 1,108 wells. Water levels measured in each well were used to define predevelopment groundwater conditions in each aquifer. Each water-level measurement in the study area was reviewed for correctness and accuracy, assigned to the proper open interval, examined to determine the hydrologic condition at the time of measurement, and flagged to indicate if the level reflects predevelopment conditions. The evaluation ensures the integrity of the data and identifies the water levels that best represent predevelopment conditions. A large part of the water-level analysis was supported by on-going and completed comprehensive evaluations of water levels in the NTS area (Fenelon, 2000, 2005, 2006; Fenelon and Moreo, 2002). All water levels and well-construction information are stored in the NWIS database and can be accessed from the world-wide web at http:// waterdata.usgs.gov/nv/nwis/gw.

Well hydrographs and locations can be displayed interactively from a Microsoft ${ }^{\oplus}$ Excel workbook (appendix 1). The workbook is designed to be an easy-to-use tool to view water levels and other associated information for wells in the study area. Information for an individual well can be selected by using the AutoFilter option available in Excel. An example of the information available in the appendix is provided for well ER-12-4 main in figure 4. The information presented on the workbook page includes measurement method, accuracy, and status for each water level.

Most hydraulic heads computed from depth-to-water measurements provided in appendix 1 are considered accurate to within $5 \mathrm{ft}$. In most cases, actual depth-to-water measurements made on the NTS are accurate to $1 \mathrm{ft}$ or less, depending on the method of measurement. Errors caused by borehole deviation in the conversion from depth-to-water to hydraulic head generally are less than $0.5 \mathrm{ft}$. Where errors are known to be larger, the measured water levels were corrected for borehole deviation. Hydraulic heads for nonsurveyed wells, most of which are located off of the NTS, may be in error by 5 to $20 \mathrm{ft}$ depending on the method used to assign the well a land-surface altitude. The accuracy of the land-surface altitude for each well in the study area is provided in appendix 2. In cases where uncertainty or error may exceed $5 \mathrm{ft}$ and the well was used for potentiometric contouring, the hydraulic head is followed by a " \pm " symbol on the potentiometric maps. Additionally, in rare cases, heads are followed by the " \pm " symbol when specific information about a well (not related to land-surface altitude) suggests that the error in the calculated value of a head exceeds $5 \mathrm{ft}$. Two examples of this type of inaccuracy are (1) insufficiencies in the supporting data to accurately correct a water level for borehole deviation and (2) uncertainties in the well completion as related to sealing-off the targeted aquifer. 


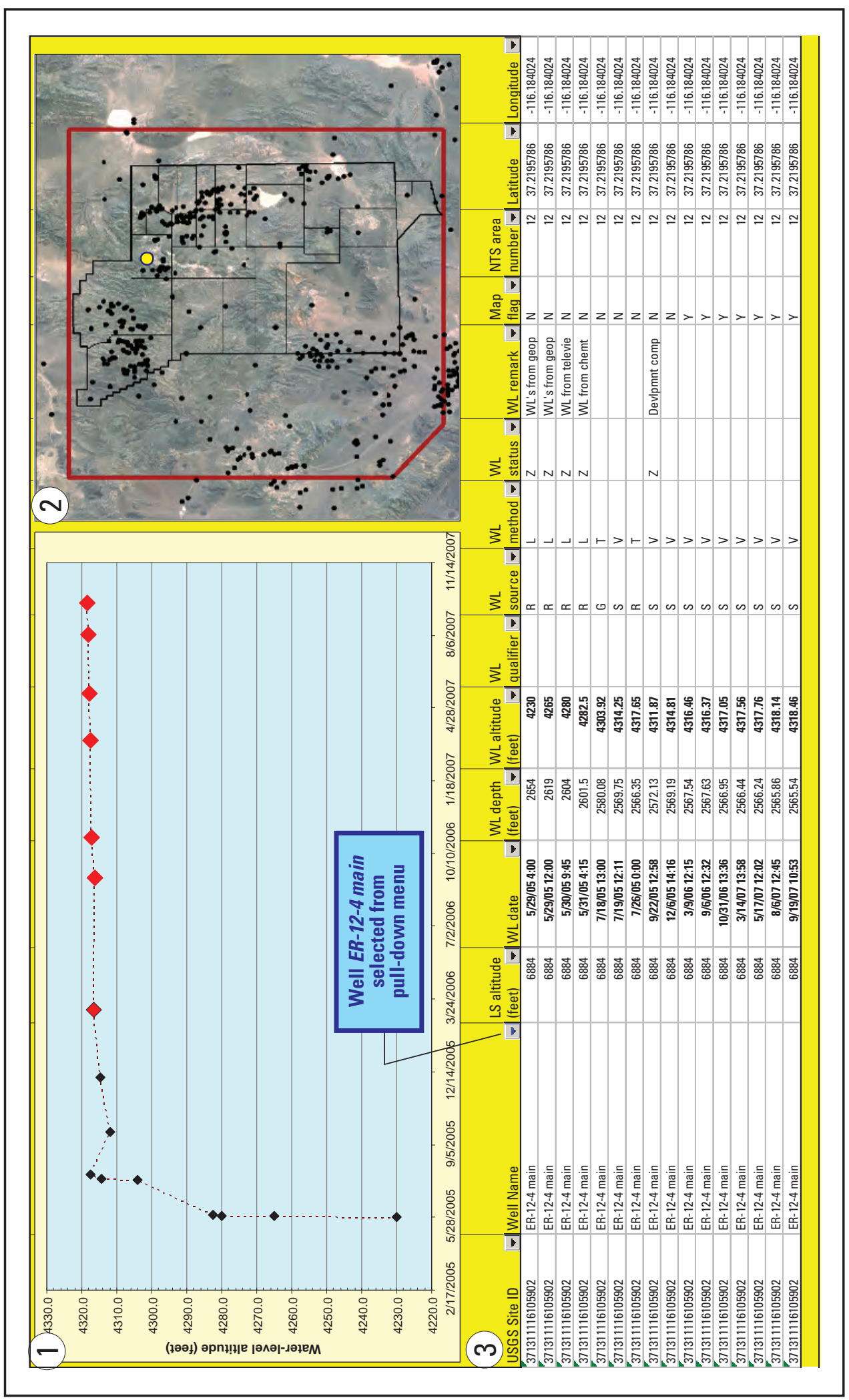

Figure 4. Example from appendix 1 Excel workbook showing water levels that were analyzed in well ER-12-4 main, Nevada Test Site area, Nevada. After a well is selected from pull-down menu, the worksheet is populated with (1) a hydrograph of all water-level measurements for the selected well—measurements used in contouring are shown as red diamonds; (2) a map showing the selected well location as a yellow circle; and (3) a table of water-level data for the selected well. All abbreviations shown in figure are explained in appendix 1. 
Hydraulic head at each well opening commonly is represented by the water-level altitude in the well. However, hydraulic head is dependent on the density of the water, which in the study area is affected primarily by water temperature. Wells in the study area that have a long (several thousand feet) water column (appendix 2) in combination with a warm water-column temperature (more than $10^{\circ} \mathrm{F}$ greater than typical groundwater temperatures of about $86^{\circ} \mathrm{F}$ ) could have a temperature-equivalent hydraulic head that is several feet or more lower than would be computed directly from the depthto-water measurement. Throughout most of the study area, horizontal gradients are sufficiently large that temperature effects will not alter the interpretation of the groundwater flow. An attempt was made in this report to adjust water-level measurements for variations in water temperature, primarily in order to account for potentially large (greater than $5 \mathrm{ft}$ ) errors that might mask or alter the true hydraulic gradient in areas of small horizontal or vertical head change. Such adjustments, however, account only for density effects caused by differences in the water temperature within measured well bores. Attempts were not made to account for buoyancy-driven flow potentially caused by the local heating of water in areas of high heat flow.

Temperature adjustments were computed for the 175 wells that had more than $1,000 \mathrm{ft}$ of water column above the mid-point of the open interval (appendix 2); wells with shorter water columns were assumed to have small (less than $5 \mathrm{ft}$ ) temperature adjustments. The effect that water temperature has on the estimate of hydraulic head in a well can be determined if the mean water temperature and length of the water column above the point of inflow in a well are known. The following equation, described by Winograd (1970), was used to calculate a water-level correction required to account for the effect of water temperature on the height of the water column:

where

$$
n^{\prime}=\frac{s}{s^{\prime}} * n
$$

$\mathrm{n}$ ' is the temperature-corrected length of water column above the point of inflow for a given temperature adjustment, in feet;

$n$ is the measured water-column length above the point of inflow (assumed to be the middle of the open interval, in this report), in feet;

$\mathrm{S}$ is the specific weight (or density) of water in the water column at the mean measured watercolumn temperatue and hydrostatic pressure, in kilograms per cubic meter; and

$S$ ' is the specific weight (or density) of water at the adjusted temperature (an adjusted temperature of $86^{\circ} \mathrm{F}$ was used in this report) and identical hydrostatic pressure, in kilograms per cubic meter.
The Thiesen-Scheel-Diesselhorst equation (McCutcheon and others, 1993) can be used to calculate the density of pure water for a specified temperature:

$$
\rho=1000\left[1-\frac{(T+288.9414)}{508929.2 *(T+68.12963)}(T-3.9863)^{2}\right] \text {, }
$$

where

$\rho$ is density of water, in kilograms per cubic meter; and;

$\mathrm{T}$ is temperature of water, in degrees Celsius.

The estimated mean water-column temperature and water-column length of the 175 wells analyzed for temperature effects are provided in appendix 2. Water-column temperature data were derived primarily from Blankennagel and Weir (1973), Pottorff and others (1987), Sass and others (1988), Gillespie (2005), and Reiner (2007). Of the 175 wells, 45 had temperature adjustments that exceeded $5 \mathrm{ft}$, which was calculated by using equations 1 and 2 . For each of these 45 wells, the mean hydraulic head used for potentiometric contouring was temperature adjusted (appendix 2), and its temperature-adjusted value is italicized on plates 3 and 4 .

Temperature adjustments in appendix 2 only approximate the magnitude of the effects of water temperature on hydraulic-head estimates. Each of the assumptions used in determining temperature adjustments to water levels - the mean temperature of the water column, an effective watercolumn length extending from the middle of the open interval to the water surface, and adjustment of all water temperatures to $86^{\circ} \mathrm{F}$ - have an effect on the estimated temperature adjustments. Determining the zone(s) of inflow is critical in wells with several thousand feet of open interval because density corrections are applied only to the length of the water column above the lowest zone of inflow. In wells with long open intervals, the potential for large errors in the temperature adjustment is great. For example, in a worstcase scenario, well U E-20f (4456-13686 ft) has a 9,230-foot open interval. Estimates of the temperature adjustment for this well, assuming the zones of inflow occur at the top, mid-point, or bottom of the open interval, are 10, 94, and $295 \mathrm{ft}$, respectively. Therefore, if the mid-point of the open interval is used for calculating the temperature correction, the error in the temperature adjustment from using a potentially incorrect point of inflow is as much as $201 \mathrm{ft}(295 \mathrm{ft}-94 \mathrm{ft})$. The potential inflow-point error in temperature adjustment was calculated for the 175 aforementioned wells. Wells with greater than $5 \mathrm{ft}$ of potential error in temperature adjustment are noted in appendix 2 and are flagged on plates 3 and 4 with a " \pm " symbol appended to the end of the posted hydraulic head. 


\section{Estimation of Predevelopment Hydraulic Heads}

Water levels in each well were evaluated to determine if and which water levels represent predevelopment hydrologic conditions. Hydrograph trends were analyzed and water levels that were attributed to unnatural influences associated with recent well construction, pumping, nuclear testing, or other human activities near the well were filtered from the datasets. Of the 1,108 wells analyzed for this study, 800 of the wells (appendix 2) had at least one water level identified as being representative of predevelopment conditions. Locations and borehole names for most of these 800 wells (some wells are in the buffer zone surrounding the study area) are shown on plate 1.

A single estimate of hydraulic head was used to represent predevelopment conditions in each of the 800 wells identified as having at least one predevelopment water level (appendix 2). For wells with multiple measurements, the mean of the predevelopment measurements was used as the predevelopment hydraulic-head estimate. A synoptic set of water-level measurements for all wells in the study area would have been preferred to using mean water levels, but such a set could not be developed because many of the wells previously measured have been destroyed and current hydrologic conditions monitored by some existing wells no longer represent predevelopment conditions. The error associated with comparing water levels that span decades is assumed to be relatively minor because long-term, naturally occurring, water-level fluctuations generally are less than $5 \mathrm{ft}$. Water levels used to estimate the predevelopment head at each of the 800 wells listed in appendix 2 are shown as large red diamonds on hydrographs that can be plotted interactively by using appendix 1 (fig. 4).

The predevelopment estimate of the hydraulic head was determined from a single water-level measurement in 263 of the 800 wells. In about one-half of these 263 wells, the single measurement represents transient, non-equilibrium conditions and thus could be used only as an upper or lower bound for the predevelopment head. For example, on a rising water-level hydrograph that has not yet reached equilibrium, the last water level can be used as a lower bound for the expected predevelopment head in the well. In this example, if the altitude of the last water-level measurement was $1,000 \mathrm{ft}$, the predevelopment head is expected to be greater than $1,000 \mathrm{ft}$. For measurements made in a dry well, the altitude of the bottom of the well is assigned a "less than" qualifier and is used as an upper bound for contouring. Only hydraulic heads calculated from mean water levels representing predevelopment conditions, or those that were assigned a qualifier to constrain the predevelopment head, were used to guide the contouring process. One of four qualifiers could be used with a hydraulic head: "less than" $(<)$, "less than or equal" $(\leq)$, "greater than" $(>)$, or "greater than or equal" $(\geq)$. The use of " $\leq$ " or " $\geq$ "indicates that the hydraulic head is most likely within a few feet of approximating a predevelopment head. A "<" or "> " qualifier provides no information about how close a hydraulic head is to approximating a predevelopment head.

\section{Assignment of Hydraulic Heads to Subsurface Hydrologic Unit Types}

The predevelopment estimate of the hydraulic head for each well was assigned to a subsurface hydrologic unit type (SHUT). The assignment is made in accordance with the SHUT encountered at the open interval (appendixes 2 and $\underline{3}$ ). Wells with long open intervals commonly penetrate multiple SHUTs. In these cases, heads generally were associated with the most transmissive SHUT. In most cases, the top and bottom SHUT altitudes at each well location were determined from the hydrostratigraphic framework models (HFM). The HFM altitudes, in general, are in good agreement with lithologic logs (Wood, 2007). The assignment of the contributing SHUT based on the HFM provides a consistent method for assigning hydraulic heads to SHUTs across the entire study area. For instances in which a well is located in overlapping HFMs, the HFM used to assign a SHUT was based on the following hierarchy of use: Rainier MesaShoshone Mountain, Yucca Flat-Climax Mine, Frenchman Flat, Pahute Mesa, and Death Valley regional flow system. For some of the wells located outside the area covered by hydrostratigraphic framework models for the Underground Test Area Project (fig. 1), the lithologic log was considered to be a better resource than the Death Valley regional flow system HFM for determining the SHUTs that contribute water to a well's open interval (appendix 3). In these cases, the units identified on the lithologic log were reinterpreted as SHUTs, prior to their assignment to hydraulic heads.

The HSUs and corresponding SHUTs for wells having predevelopment heads can be displayed interactively from a Microsoft ${ }^{\circledR}$ Excel workbook (appendix 3). The workbook is designed to view the stratigraphic column interpreted from the HFM, the mean water level used to develop the predevelopment head, and basic well-construction information for wells in the study area. Information for an individual well can be viewed by selecting the well from the column-header dropdown list. An example workbook page for well ER-124 main is shown in figure 5 . 


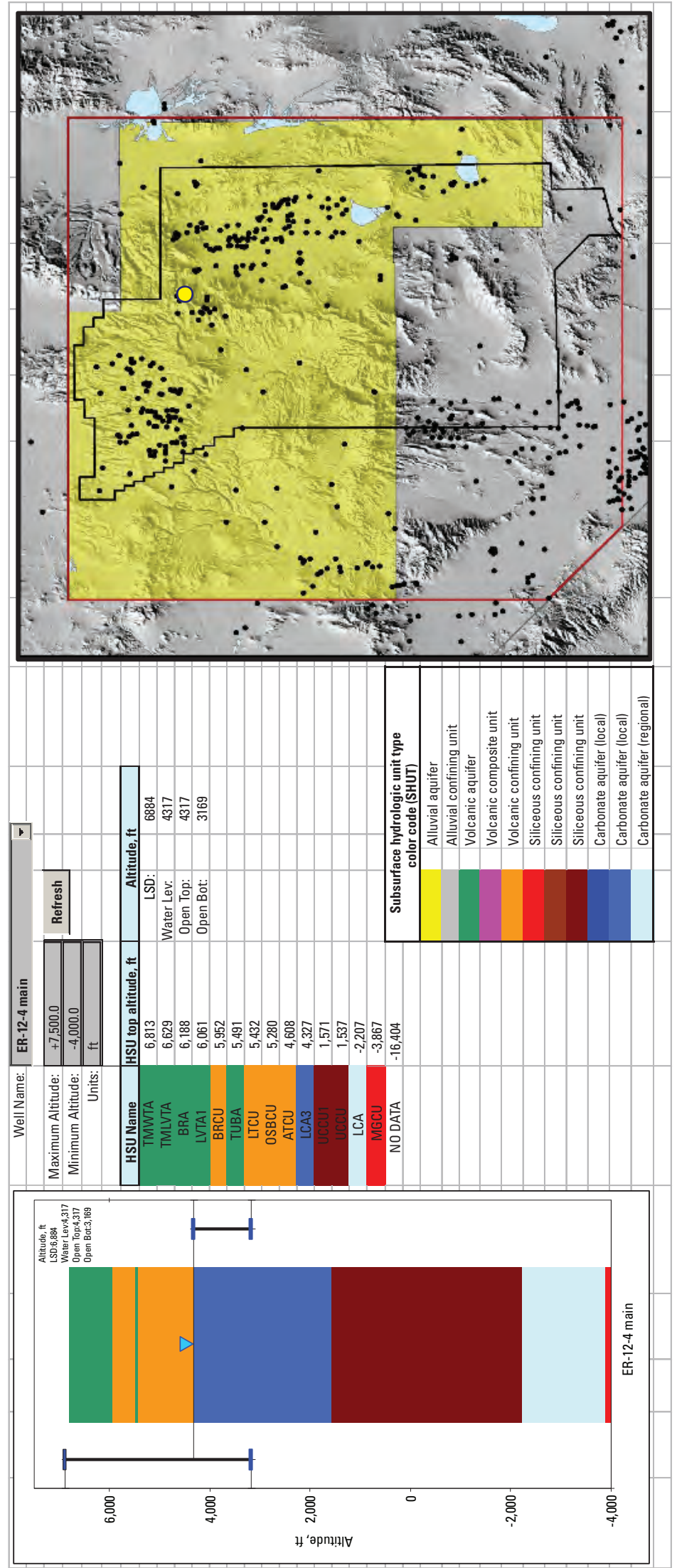

Figure 5. Example from appendix 3 Excel workbook showing hydrostratigraphic units and their relation to water level and open intervals in well ER-12-4 main, Nevada Test Site area, Nevada. 
Each predevelopment-head estimate is assigned a single hydrologic qualifier that describes how the estimate was used in the process of contouring hydraulic heads (appendix 2). The four assigned hydrologic qualifiers describe the hydraulic head as:

- representative of the assigned SHUT and used for contouring;

- representative of the assigned SHUT but of limited use in contouring;

- elevated relative to the assigned SHUT and not used for contouring; or

- depressed relative to the assigned SHUT and not used for contouring.

Hydraulic heads assigned to a SHUT designated as an aquifer or composite unit were plotted and contoured. Heads assigned to the alluvial, volcanic, and siliceous confining unit SHUTs (appendix 2) were used to constrain contours within the aquifers and were selectively plotted.

Where the direction of the vertical hydraulic gradient is known, a hydraulic head from a well open to a confining unit was used to constrain contours in an overlying or underlying aquifer, and consequently, is assigned to the aquifer but given a "<" or "> " qualifier. For example, at a location with a known downward vertical hydraulic gradient, a predevelopment head from a well open to the volcanic confining unit is assigned to the underlying volcanic aquifer with a " $<$ " qualifier.

\section{Development of Potentiometric Contours}

The configuration and extent of regional and local aquifers within each of the two aquifer types are based on the distribution and lateral and vertical extent of its component SHUTs. The magnitude of the difference between hydraulic heads from wells in the same aquifer type was used to help evaluate aquifer continuity. For example, where the continuity between two areas of the same aquifer type was in question, the similarity or difference in the hydraulic head was used to support or refute a hydraulic connection.

Hydraulic heads in the aquifers were contoured manually. In rare cases, posted heads are inconsistent with potentiometric contours on plates 3 and 4 . Any discrepancy between contours and data typically are minor (less than $5 \mathrm{ft}$ ) and commonly are the result of differences in hydraulic heads from closely spaced wells. In most cases, the inconsistency between posted and contoured heads can be attributed to local vertical hydraulic gradients, unrecognized hydrologic anomalies, or small measurement errors. Posted hydraulic heads that were disregarded during contouring, usually because they are considered elevated or depressed, are shown as red text on plates 3 and 4 . As part of the manual contouring process, potentiometric contours were configured in accordance with known or inferred hydraulic gradients, recharge areas, discharge areas, lateral and vertical continuity of flow systems, and the known or inferred geology. Specific examples of this manual process include the following: (1) in areas where recharge is inferred, contours reflect an elevated potentiometric surface even if head data are absent; (2) in areas where a fault juxtaposes a confining unit to form the boundary of an aquifer, contours are constructed perpendicular or nearly perpendicular to the inferred flow barrier; (3) in areas where a fault or fault zone is inferred to impede flow within the aquifer, contours are configured in a tighter pattern to portray an increase in the local head gradient upgradient of the inferred flow barrier; and (4) in areas where a fault or fault zone is inferred to be highly transmissive, contours are constructed convexly to the general flow direction to reflect a preferred flow path.

Contours are portrayed with three types of lines: solid, short dash, and long dash. Solid lines portray the highest level of certainty, whereas dashed lines suggest uncertainty. Short dashes are used where uncertainty results from little or no data. Long dashes are used where data are present but can be interpreted in more than one way. Long dashes suggest that the degree of uncertainty in the contours is related to uncertainty in the conceptual interpretation of the flow system.

\section{Potentiometric Contours and Conceptualization of Flow}

Potentiometric contours commonly are used to represent the spatial distribution of hydraulic head across an aquifer or flow system. Contours interpreted from heads given in appendix 2 and from known or inferred subsurface geology are shown for the alluvial-volcanic aquifer on plate 3 and for the carbonate aquifer on plate 4 . Hydraulic heads representing these aquifers, and specifically used in the contouring process, are posted on the plates. Heads representing confining units were used to constrain contours within an aquifer. Selected confining-unit heads that support interpretations of flow in the aquifers are posted on plates 3 and 4 ; all head data for confining units are given in appendix 2.

Contours represent the predevelopment potentiometric surface in the shallow part of mapped regional aquifers. These contours also approximate the current potentiometric surface because most of the potentiometric response to pumping or past nuclear testing is interim and localized. The shallow part of the aquifer typically is that part best represented by available data and is defined arbitrarily as the portion that is within about $6,000 \mathrm{ft}$ of land surface. This shallow focus provides information most pertinent to quantifying the hydraulic potential that controls the transport of test-generated radionuclides. This is because most nuclear devices were detonated in unsaturated, perched, or semi-perched rock or in the uppermost saturated zone at or near the water table. Once radionuclides reach the saturated zone, they likely will remain at relatively shallow depths as they are transported toward 
downgradient discharge areas. Although regional flow occurs in the deep part of the aquifers across the study area, this water most likely originated as recharge in areas far upgradient of the NTS and its interaction with water in the shallow flow systems is believed to be minimal (Tóth, 1962; Freeze and Witherspoon, 1967).

Additionally, flow into and within the deep part of the regional aquifers may be restricted by vertical anisotropy and an overall decrease in the hydraulic conductivity with depth, especially in unconsolidated rock. Hydraulic conductivity within an aquifer may decrease with depth as a result of various geologic conditions that could cause a loss of primary porosity and permeability including: (1) increasing compaction and cementation with depth of originally unconsolidated sediment; (2) zeolitic alteration of volcanic glass in nonwelded tuff in the saturated zone; (3) hydrothermal alteration within calderas and near intrusive bodies; and (4) potential closing of bedding plane partings and specific fracture orientations in competent rocks as lithostatic load and overburden pressure increases. Although a decrease in hydraulic conductivity with depth has not been well documented by aquifer-test data, investigators have found it necessary to decrease the values of hydraulic conductivity to achieve calibration of many of the flow models developed in and around the study area (U.S. Department of Energy, 1997a; Faunt, Blainey, and others, 2004; DeNovio and others, 2006; Ruskauff and others, 2006).

The hydraulic gradient, which influences the direction and rate of groundwater flow and contaminant movement within an aquifer, can be approximated from spatial differences in the contoured potentiometric surface. The general flow direction, as defined by these contours, is shown on plates 3 and 4 by arrows within the mapped extent of each aquifer. The arrows indicate not only flow direction, but by their size, the relative amount of flow. The relative amount of flow for a given point in the aquifer is approximated from reported outflows at downgradient discharge areas and inferred amounts of recharge, leakage, and flow to the aquifer from upgradient areas. Flow directions establish primary flow paths and are used to help delineate flow systems.

Regional alluvial-volcanic and carbonate aquifers provide the framework for flow systems and tributary flow systems that are mapped in the study area (pls. 5 and 6). These mapped flow systems lie entirely within the major flow system referred to as the Death Valley system by Harrill and others (1988, sheet 1). A major flow system, as defined by Harrill and others (1988) is a flow system that "conveys the largest percentage of water in the area." Small, intermediate, and local flow systems that discharge water at intermediate, internal locations also were defined by Harrill and others (1988), but not specifically delineated. Flow systems and tributary flow systems, as used in this report, are of the intermediate scale. A tributary flow system delineates an area of a regional aquifer with recharge areas and flow paths that may contribute water of a unique geochemistry to a downgradient flow system. Internal boundaries between a flow system and its upgradient tributary flow systems represent general zones of transition. Data are insufficient to precisely locate these transitions and their mapped locations could be in error by several miles.

Tributary flow systems are named after prominent physiographic features within these systems. A flow system, which accepts water from tributary flow systems and is likely to have a mixed geochemical signature, is named for its downgradient discharge area. The names of tributary flow systems, as first introduced in Fenelon and others (2008) in their work that focused on Rainer Mesa (a subset of the study area), generally are consistent with usage in this report.

Delineated flow systems (and their tributary components) are presented and discussed in later sections and generally describe the most likely groundwater flow path or paths away from underground nuclear test areas. Transport is not necessarily confined to an individual aquifer. Under certain conditions, contaminants can move vertically or laterally across confining units or between aquifers that are hydraulically connected. The potential for transport of test-generated contaminants across mapped aquifers is evaluated, and is in part reflected in the distribution of the delineated flow systems. Inherent in the interpretations of flow presented in the following sections are uncertainties in the geology and hydrology. These uncertainties most often can be attributed to a lack of data and are likely to have significant implications on the conceptualization and ultimately the simulation of contaminant transport.

\section{Alluvial-Volcanic Aquifer}

The alluvial-volcanic aquifer consists primarily of permeable alluvium and volcanic rocks and is mapped on plate 3. Areas of the alluvial-volcanic aquifer are classified as either regional or local aquifers (fig. 2). The assignment of an alluvial-volcanic aquifer as either regional or local was based on the lateral and vertical extent of the component SHUTs and their hydraulic continuity or isolation with adjacent aquifers. Thick, contiguous blocks of volcanic aquifer, volcanic composite unit, and alluvial aquifer materials are considered regional if they are hydraulically connected to adjacent aquifers and together form part of a large flow system. Local alluvial-volcanic aquifers are stratigraphically or structurally isolated, hydraulically restricted, and generally drain only to adjacent confining units.

The alluvial-volcanic aquifer is further subdivided into shallow and deep parts. Unlike the carbonate aquifer, the deep part of the alluvial-volcanic aquifer is present only locally and is always overlain by shallow aquifer; therefore, the deep alluvial-volcanic aquifer is apparent only in section view (sections A-A' and C-C', pl. 2). 


\section{Nature and Extent}

The alluvial-volcanic aquifer includes Pliocene and younger, generally unconsolidated alluvium, and Miocene volcanic rocks (iggs. 2 and $\underline{3}$ ). The alluvial aquifer, although dominated by alluvium, also includes colluvium, eolian sands, and minor basin-filling deposits such as playa sediments, freshwater limestones, and thin lava flows that are interspersed within alluvium. Alluvial units are widespread in map view and are most prevalent in the eastern half of the NTS and in the valleys southeast and southwest of the NTS (Slate and others, 1999). However, the saturated parts of these young deposits that form alluvial aquifers typically are thin and of limited extent. Volcanic rocks and their associated calderacollapse structures dominate the northwestern and west-central parts of the NTS (Byers and others, 1976; Sawyer and others, 1994). Fractured volcanic rocks within and adjacent to the calderas at the NTS are sufficiently extensive and locally thick enough to be an important regional aquifer. Where saturated, overlying alluvial deposits are grouped together with underlying volcanic rocks to form the alluvial-volcanic aquifer (pl. 3).

Two areas of regional alluvial-volcanic aquifer are mapped in the study area (pl. 3). By far, the largest regional alluvial-volcanic aquifer is in the western half of the study area. This aquifer, which underlies Pahute Mesa to the north and extends southward into the Amargosa Desert, hosted all 85 underground nuclear tests done on Pahute Mesa. In most places where it occurs in the study area, this aquifer is dominated by volcanic rocks; however, the southern part of the aquifer, south of the NTS, is composed entirely of alluvium (section D-D ', pl. 2). A smaller regional aquifer, mostly outside the NTS, underlies Emigrant Valley in the northeastern corner of the study area. Most of the alluvial-volcanic aquifers in the eastern half of the study area are of local extent and are physically and hydraulically isolated from the regional flow system (section E-E', pl. 2; pl. 3).

Large-volume eruption of regionally extensive ash-flow tuff resulted in the collapse of six known calderas (pl. 3), including the Black Mountain caldera to the northwest of the NTS; two calderas, Grouse Canyon and Silent Canyon, which overlapped to form the Silent Canyon caldera complex (Sawyer and others, 1994); the Claim Canyon caldera; and the nested Rainier Mesa and Ammonia Tanks calderas, which form the Timber Mountain caldera complex (Byers, Carr, Orkild, and others, 1976; Byers, Carr, Christiansen, and others, 1976; Sawyer and others, 1994). Additionally, the existence of a buried Redrock Valley caldera to the south of Rainier Mesa (pl. 3) has been proposed on the basis of the distribution of older ash-flow tuffs and the presence of a subtle gravity low to the east of the Rainier Mesa caldera (Hildenbrand and others, 2006; National Security Technologies, LLC, 2007).
Similar to many mapped calderas throughout the Great Basin (Best and others, 1989; Ludington and others, 1996), several of the calderas at the NTS have broadly arcuate or circular shapes that result from the near-instantaneous evacuation of a shallow magma chamber. In contrast, geophysical and drill-hole evidence suggest that the Silent Canyon caldera complex formed a somewhat rectilinear shape as a result of localization of structural collapse along pre-existing faults (Ferguson and others, 1994; Warren and others, 2000). In particular, the northwestern margins of the Silent Canyon and Timber Mountain caldera complexes appear to have formed along a southwest-trending linear boundary extending from the northwestern corner of the Silent Canyon caldera complex to Oasis Valley. This linear boundary has abrupt geophysical expression and is interpreted from geophysical data to be a pre-existing fault zone (Grauch and others, 1999; Mankinen and others, 2003).

Caldera-forming volcanic eruptions at the NTS during the Miocene produced large volumes of volcanic rocks that include welded and nonwelded tuff of rhyolite-to-dacite composition, as well as local accumulations of basalt and rhyolite lava. The volcanic environment during calderaforming eruptions produces three general types of volcanic units: heterogeneous volcanic material deposited within the caldera, called intracaldera deposits; ash-flow sheets, called outflow-tuff deposits that are deposited outside of, but proximal to, the caldera; and regionally distributed air-fall tuffs that may be deposited at great distances from the caldera. The aggregate thickness of the outflow-tuff deposits can be thousands of feet, such as at Yucca Mountain to the south of the Claim Canyon caldera (section B-B', pl. 2), Oasis Valley to the west of the Rainier Mesa and Ammonia Tanks calderas (section C- $C^{\prime}$, pl. 2), and at Rainier Mesa to the northeast of the Rainier Mesa and Ammonia Tanks calderas (section D-D ', pl. 2). Intracaldera volcanic accumulations can be from 10,000 to $15,000 \mathrm{ft}$ thick (Best and others, 1989; Sweetkind and du Bray, 2008), such as at Black Mountain (section A-A', pl. 2), within the Rainier Mesa and Ammonia Tanks calderas (sections A-A' and C-C', pl. 2), and within the Silent Canyon caldera complex (section $C-C^{\prime}$, pl. 2).

Volcanic rocks display a wide range of hydraulic properties, both vertically and horizontally, because of their variable lithology and degree of welding. The hydraulic properties of these volcanic deposits depend mostly on the mode of eruption and cooling, on the extent of primary and secondary fracturing, and on the degree to which secondary alteration (crystallization of volcanic glass and zeolitic alteration) has affected primary permeability (Laczniak and others, 1996). Outflow-tuff sheets, which comprise many of the volcanic aquifers at the NTS, are regionally distributed and may provide lateral continuity for water to move unimpeded over long distances through the regional alluvial-volcanic 
aquifer; they also typically have well-connected fracture networks and minimal secondary alteration (Blankennagel and Weir, 1973). Fractured rhyolite lava flows and vitric ash-fall tuffs also are included as part of the volcanic aquifer, but are relatively restricted areally (Prothro and Drellack, 1997). The margins of calderas juxtapose intracaldera and outflow-facies volcanic rocks. The intracaldera environment is usually filled by thousands of feet of heterogeneous accumulations of ashflow tuff, interleaved landslide materials, and thick lava flows (Smith and Bailey, 1968; Lipman, 1984); these accumulations at the NTS generally are classified hydrogeologically as volcanic composite units (fig. 3 ). Intracaldera rocks differ in their geometry and material properties from equivalent outflow tuff in having greater thicknesses of welded material and more complex welding zonation, greater lithologic diversity, and a greater degree of secondary alteration (Blankennagel and Weir, 1973). Volcanic confining units generally have low fracture permeability and include air-fall tuff and nonwelded or partly welded tuff. The permeability can be further reduced in nonwelded tuff by zeolitic alteration of rock-forming minerals and glass to zeolite, clay, carbonate, silica, and other minerals in the older, deeper parts of the volcanic sections (Laczniak and others, 1996). Volcanic confining units may be interbedded with welded-tuff aquifers to form a complex package of alternating volcanic aquifers and confining units, such as at Pahute Mesa; where data are insufficient or the geology is highly variable, this complex package is mapped as volcanic composite unit (section $A-A^{\prime}$ and $C-C^{\prime}$, pl. 2). The hydraulic properties of the volcanic rocks underlying Pahute Mesa and the larger Death Valley regional flow system were described by Blankennagel and Weir (1973) and Belcher and others (2001), respectively.

The alluvial confining unit includes a complex interfingering of basin-fill lithologies such as nonwelded tuffs, and fluvial, spring-deposit, and lacustrine sediments (see worksheet "SHUTtoHSU_Chart" in appendix 3). Sedimentary rocks rich in volcanic ash in the Amargosa Desert are included in this unit (section $D-D^{\prime}, \mathrm{pl} .2$ ). The alluvial confining unit ranges in age from late Eocene to Pliocene and generally underlies younger alluvial sediments assigned to the alluvial aquifers. The thickest intervals of alluvial confining unit underlie alluvial-volcanic aquifers and occur near the bottoms of the Cenozoic basins, such as in Frenchman Flat (section A-A', pl. 2) and Crater Flat (section B-B', pl. 2). The alluvial confining unit is locally important as a hydraulic barrier between the alluvial-volcanic aquifer and the underlying carbonate aquifer. Evidence of this barrier effect was demonstrated in packer tests conducted in borehole UE-25p 1 PTH (section B-B', pl. 2); the tests indicated a major hydraulic barrier in the volcanic and sedimentary units composing the alluvial confining unit. Upward flow of water from the carbonate aquifer into the alluvial-volcanic aquifer is impeded by this intervening confining unit (Craig and Robison, 1984).
The alluvial-volcanic aquifer is cut locally by generally north-striking normal faults in Yucca Flat and Yucca Mountain (pl. 3). Yucca Flat is the main extensional basin of the eastern NTS, and in general terms, is a simple half-graben. Yucca Flat is dominated by north-striking, east-dipping, down-to-the-east normal faults, such as the Yucca and Carpetbag-Topgallant faults (Carr, 1984; Dockery, 1984). Normal faults at Yucca Mountain are north- to northeast-striking, west-dipping, and are dominated by west-side-down throws that can exceed 1,000 feet (Scott and Bonk, 1984; Day and others, 1998). Principal among these are the Paintbrush Canyon, Solitario Canyon, and Windy Wash faults (pl. 3). The west-dipping Gravity fault (pl. 3) lies to the southeast of Yucca Mountain. The Gravity fault has a total displacement of about 3,000 ft across several fault splays, based on regional gravity data (Winograd and Thordarson, 1975), seismic-reflection data (Brocher and others, 1993), and drill-hole data (Carr and others, 1995).

The alluvial-volcanic aquifer also is cut locally by generally east-striking faults that lie transverse to interpreted groundwater flow directions, and as a consequence, form important local structures. The Highway 95 fault (Potter, Dickerson and others, 2002) is inferred to exist at the northern end of the Amargosa Desert, south of Crater Flat (section D-D', pl. 2; pl. 3). The fault is interpreted to have north-side down and possible strike-slip offset. A similarly complex fault, the Colson Pond fault (section C - $C^{\prime}$, pl. 2; $\mathrm{pl} .3$ ) has been interpreted in the Oasis Valley area (Fridrich and others, 2007).

\section{Hydraulic Heads and Contours}

Hydraulic heads in the alluvial-volcanic aquifer and the potentiomentric contours drawn on the basis of those heads are shown on plate 3 . The heads and contours provide information about flow directions and the hydraulic connection or isolation of the regional and local aquifers.

\section{Regional Aquifers}

Hydraulic heads in the extensive regional alluvialvolcanic aquifer in the western half of the study area are highest beneath Pahute Mesa, Rainier Mesa, and the Belted Range. These physiographic features form a prominent highland in the north-central part of the study area, where local precipitation infiltrates downward and recharges the underlying aquifers (pl. 3). Heads decrease to the west and south of this local recharge area and range from 4,996 ft in well ER-19-1-2 (middle) to about 2,277 ft in well HA-AD 16 (pl. 3). Contours constructed from the head data reflect this observed trend and range from 5,000 ft in the Belted Range and Rainier Mesa areas to 2,300 ft in the Amargosa Desert. 
As portrayed by the mapped contours (pl. 3), much of the groundwater that flows through the regional alluvialvolcanic aquifer in the western half of the study area originates at the local highland in the north-central part of the study area. The 4,800-, 4,900-, and 5,000-foot contours are drawn to imply that there is recharge to this area, but are poorly constrained because of a lack of data. Local recharge from the highland area is evidenced by downward hydraulic gradients computed throughout most of the recharge area (see hydraulic heads from wells completed in boreholes TW-1, U -19d 2, UE-19c, UE-19fS, and WW-8 in appendix 3). The presence of groundwater elevated above the regional potentiometric surface (shown on plate 3 as anomalously high heads) is common in the recharge area. These elevated heads typically are associated with wells open to an aquifer and confining unit or open to an aquifer above confining unit. Confining units are prevalent in the shallow subsurface, as depicted near wells P M - 1 and UE-19gS (section C-C', pl. 2), and impede the downward movement of water. These areas of "elevated water" typically coincide with areas of local recharge and are assumed representative of perched or semi-perched conditions (Thordarson, 1965). Rocks containing elevated water are not considered to be part of an alluvial-volcanic aquifer, but rather, potential local sources of diffuse leakage or focused drainage into underlying or laterally adjacent aquifers.

In some areas on Pahute Mesa, distinguishing whether a hydraulic head is anomalous (generally elevated) relative to heads in the regional alluvial-volcanic aquifer is difficult. Anomalous heads often occur in areas where aquifers are stacked vertically and separated by extensive confining units. In these areas, it is possible to have multiple, semi-isolated aquifers each having a different hydraulic head. Vertical hydraulic gradients between these semi-isolated aquifers generally are downward in NTS Area 19 (NTS areas shown on pl. 1), but are more commonly upward farther west in Area 20 (appendix 2; Blankennagel and Weir, 1973). Because hydraulic-head data are insufficient to contour the head distributions within the many semi-isolated volcanic aquifers, the regional alluvial-volcanic aquifer is contoured as if it were a single continuous aquifer, and local vertical hydraulic gradients are ignored. The head differences between these semi-isolated volcanic aquifers, which can be tens of feet, are apparent in the hydraulic heads posted on plate 3 . For example, an examination of heads for boreholes on plate 3 between the 4,200- and 4,700-foot contours shows relatively large variations in heads between nearby boreholes and from different open intervals within the same hole. These variations are attributed to boreholes with openings in different semiisolated parts of the alluvial-volcanic aquifer where vertical gradients are relatively large. A systematic contouring of these variable heads required providing a best fit to the data, which honored most of the data and ignored outliers.
West of the recharge area on Pahute Mesa, the contours portray a hydraulic-head discontinuity that coincides with the northwestern boundary of the Silent Canyon caldera complex (pl. 3). The contours, which generally are consistent with contours drawn by Blankennagel and Weir (1973) and O'Hagan and Laczniak (1996), depict the western boundary of the caldera complex as a major discontinuity between flow paths in the alluvial-volcanic aquifer to the east and to the west of the boundary. The discontinuity results in heads that are several hundred feet higher west of the caldera and groundwater flow that is predominantly parallel to the discontinuity. Although potentiometric contours in this area honor the head data, the contours also are drawn to fit the conceptualization of flow in the alluvial-volcanic aquifer along the caldera boundary. Therefore, the contours are dashed to indicate uncertainty in this conceptualization.

Contours in the far northwestern part of the study area generally are oriented in a west-east direction (pl. 3). The intent of this orientation is to imply predominantly southerly flow towards the Oasis Valley discharge area rather than southwesterly flow towards the Sarcobatus Flat discharge area (fig. 1). It is equally possible that some of the water in the northwestern corner of the study area could be flowing towards Sarcobatus Flat rather than Oasis Valley. Because no hydraulic-head data are available for this area, contours are dashed to indicate uncertainty.

Immediately south of Pahute Mesa, hydraulic-head data are limited to the area surrounding Timber Mountain and are nonexistent on the mountain itself. Because of this data gap, the degree of groundwater mounding, if any, associated with potential recharge from precipitation falling on the mountain is unknown. Whether rocks and associated secondary features, such as faulting and jointing in the core of the mountain, are a barrier or conduit to groundwater flow also is unknown. Hydraulic heads are contoured to suggest a divergence of flow away from the mountain and a small influence on heads from local recharge, but no significant mounding. The 4,200-foot contour northeast of Timber Mountain is drawn with dashes to denote this conceptual uncertainty.

Oasis Valley is the only major discharge area in the study area. Here, groundwater discharges from the many local springs and seeps (pl. 3). The 3,900- to 3,300-ft contours surrounding this valley are well constrained by data and show a prominent " $\mathrm{V}$ " shape along the valley, supporting the valley's designation as an area of major discharge. Vertical hydraulic gradients in Oasis Valley as determined from nested wells (ER-OV-01, ER-0V-06a, and ER-0V-06a2; ER-0V-3a and ER-O V-3a3; and Springdale ET D eep and Springdale ET Shallow Wells) are upward, also indicating a groundwater discharge zone (appendix 2; pl. 3). As portrayed by contours and flow arrows on plate 3 , most of the water that flows through the Pahute Mesa area of the NTS is assumed to be discharged by springs and seeps in Oasis Valley. 
An area of high groundwater gradient is present to the east of Oasis Valley and south of Timber Mountain (pl. 3). Contours tighten significantly from about $50 \mathrm{ft} / \mathrm{mi}$ just south of Timber Mountain to more than $300 \mathrm{ft} / \mathrm{mi}$ on the northern end of Yucca Mountain. West-east trending contours decline from $3,800 \mathrm{ft}$ to $2,600 \mathrm{ft}$ over a distance of 2 to $4 \mathrm{mi}$. These contours are poorly constrained by head data and, consequently, are dashed. Although the exact location and magnitude of the gradient are uncertain, there is little doubt that heads decline rapidly in this area. The calculated horizontal gradient between wells USW G-2 and U SW WT-24 (pl. 3) is more than $1,000 \mathrm{ft} / \mathrm{mi}$. Even if heads in these two wells are perched, as suggested by Ervin and others (1994), the minimum horizontal gradient is still relatively high ( $200 \mathrm{ft} / \mathrm{mi})$ between wells ERE C -7 at the southern end of Timber Mountain and UE -25 WT 16 at the northern end of Yucca Mountain. The cause of the high gradient has not been determined but likely is caused by a permeability contrast possibly related to geologic faulting that dams water to the north. Various explanations have been proposed for the high gradient in the area. These include a fault that creates a hydraulic barrier because the fault gouge is impermeable or, more likely, the fault juxtaposes permeable volcanic rock against less permeable rock (Czarnecki, 1989); a short-circuiting of flow in the volcanic aquifer by a preferred pathway through the underlying carbonate aquifer (Fridrich and others, 1994); and hydrothermal alteration of volcanic rocks on the southern edge of the Claim Canyon caldera, resulting in reduced permeability and high gradients (Fridrich and others, 1994; Bechtel SAIC Company, LLC, 2004). The contours and arrows on plate 3 portray the high-gradient area as a north-south barrier to flow on the north side of Yucca Mountain, with only limited groundwater flowing south through the high-gradient area.

High gradients bound three sides of Crater Flat (pl. 3), suggesting that the area is partially isolated from the rest of the regional alluvial-volcanic aquifer. Hydraulic heads within the bounds of the high-gradient area of Crater Flat (excluding heads in boreholes NC-EWDP-7S and NC-EWDP$7 \mathrm{SC}$, which are assumed to be perched) range rather tightly from 2,508 ft at well N C-EWD P-13P to 2,583 at several open intervals in borehole N C-E WD P-1S. The northern side of Crater Flat is bounded by the high-gradient area discussed in the previous paragraph. Across the southern and eastern margins of Crater Flat, potentiometric contours indicate that heads decline by 100-200 ft over a distance of $1 \mathrm{mi}$ or less. On the southern margin, the gradient change is attributed to the Highway 95 fault and the abrupt transition from volcanicdominated sediments in Crater Flat to alluvial-dominated sediments in Amargosa Desert. The gradient change along the eastern margin of Crater Flat is well-documented and may be associated with the Solitario Canyon fault and splays of the fault (pl. 3; Ervin and others, 1994; Tucci and Burkhardt, 1995; Bechtel SAIC Company, LLC, 2004).

East of the Solitario Canyon fault primarily in Jackass Flats, hydraulic heads, at about 2,390 ft, are substantially lower than west of the fault. The persistence of low heads throughout this area may be related to the alluvial-volcanic aquifer and the underlying carbonate aquifer being in direct contact, as is portrayed on section B-B' between boreholes J -13WW and J-11 WW and on section D-D' between boreholes NC-EWD P-2DB and NC-EWDP-24P (pl. 2). The absence of intervening confining unit would allow water in the alluvial-volcanic aquifer to easily drain downward into the underlying carbonate aquifer, thus minimizing the vertical hydraulic gradient by decreasing the difference in heads between the alluvial-volcanic aquifer and the carbonate aquifer in Jackass Flats.

Horizontal hydraulic gradients in the southwestern part of the study area (Crater Flat, Jackass Flats, and Amargosa Desert) are the lowest in the regional alluvial-volcanic aquifer (pl. 3). In areas where hydraulic heads are less than 2,500 ft, horizontal gradients range from about $5-10 \mathrm{ft} / \mathrm{mi}$ along Fortymile Wash to $10-40 \mathrm{ft} / \mathrm{mi}$ in the northern Amargosa Desert.

Groundwater flow in the alluvial-volcanic aquifer mapped in the western half of the study area is portrayed on plate 3 by large regional flow arrows representing the bulk of the flow through the aquifer and small lateral boundary arrows representing small inferred inflows and outflows across the boundary of the aquifer. The direction of lateral flow (that is, into or out of the aquifer) is dependent on the known or inferred local hydraulic gradient at the aquifer boundary. Along most of the aquifer's outer boundary, shallow elevated water that originates as precipitation in the local highlands ultimately leaks into the aquifer through contacts with confining unit. These areas of inferred limited inflow are shown by the small inward arrows on plate 3 . Small areas where the hydraulic gradient between the aquifer and adjacent hydrologic units is interpreted to be outward are (1) along the eastern margin of the aquifer north and directly south of Shoshone Mountain and (2) along the southeastern margin of the aquifer (pl. 3). These areas of inferred outward flow, which are represented by small outward arrows on plate 3 , result in eastward and downward flow out of the alluvial-volcanic aquifer and into adjacent confining units or local aquifers.

Hydraulic heads from the three boreholes in the smaller regional aquifer underlying Emigrant Valley in the northeastern part of the study area (pl. 3) vary by only $17 \mathrm{ft}$ $(4,368-4,385 \mathrm{ft})$, indicating a generally flat potentiometric surface and low (about $4 \mathrm{ft} / \mathrm{mi}$ ) horizontal hydraulic gradient in the aquifer. Contours are not drawn in this aquifer because of the low gradient and limited data; however, flow is interpreted to be southeastward. Small amounts of water, represented by the small inward arrows on plate 3 , are interpreted to flow laterally into the aquifer along most of its margin across contacts with confining unit. Water may leak out of the aquifer into adjacent confining unit along two short boundary sections at the southern and southeastern margins of the aquifer. In these two areas, represented by small outward arrows, water may drain south towards Papoose Lake and east towards Groom Lake (east of study area, fig. 1). 


\section{Local Aquifers}

A number of small, discrete aquifers that are mapped as local alluvial-volcanic aquifers are in the eastern half of the study area (pl. 3). These aquifers are interpreted to be isolated hydraulically from regional aquifers by a confining unit. Water in these isolated aquifers typically slowly drains laterally or vertically across a confining unit into a regional aquifer or leaks directly into a regional aquifer through a local faultinduced connection. Only a few of the local aquifers have sufficient data to draw potentiometric contours from which to interpret flow directions. All contours in these aquifers are drawn with long dashes to denote conceptual uncertainty. Many of the contours are based on limited head data and supplemented by knowledge of geologic structures thought to be important to flow, nearby recharge areas, and heads in adjacent aquifers or confining units.

Several local aquifers are in the northern part of the study area, primarily in NTS Areas 15, 12, and north of Area 12 (pl. 3). These aquifers are potentially downgradient, hydraulically, of underground nuclear tests conducted in Rainier Mesa and Climax Mine and upgradient of tests conducted in Yucca Flat. The aquifers have only a few estimates of hydraulic head, which are elevated (3,264 to $4,289 \mathrm{ft}$ ) relative to heads in local aquifers farther south. Head data are not available for the largest of these local aquifers, north of Area 12. However, heads are assumed to be high (greater than 4,500 ft) because of direct local recharge from the Belted Range. Individual volcanic aquifers within this locally mapped aquifer are extremely thin and discontinuous, as portrayed on the northern end of section D-D ' (pl. 2).

Several of the local alluvial-volcanic aquifers delineated in Yucca Flat have substantial hydraulic-head data as a result of wells drilled and completed to support past underground testing in the Yucca Flat area (U.S. Department of Energy, 2000b). Heads computed from water-level measurements in the two local aquifers mapped in western Yucca Flat (NTS Area 1 on plate 3) range from 2,909 to 3,760 ft. These heads are intermediate to heads that are high in the regional alluvialvolcanic aquifer to the west (4,000 to 4,500 ft) and heads that are low in local alluvial-volcanic aquifers in the center of Yucca Flat (2,391 to about 2,530 ft). Hydraulic heads in the intervening confining unit (wells ER-12-2 main (upper zone), UE-1L (recompleted), UE-16d WW (2117-2293 ft), UE-16f (1479 ft), and UE-17a; pl. 3; appendix 2) and the large difference in heads between the two bounding alluvialvolcanic aquifers indicate a steep horizontal hydraulic gradient across the eastern half of the study area. This steep gradient suggests limited eastward flow from the western highlands through confining unit and local volcanic aquifers into central Yucca Flat.

Available head data for the two largest local aquifers in central Yucca Flat are sufficient to merit drawing contours (pl. 3). As contoured, flow in the northern aquifer (NTS Areas 2 and 9, pl. 3; section E-E' near well U-2bs, pl. 2) has a north-northeast component. Although flow is northward in this aquifer, hydraulic gradients between this aquifer and hydrologic units to the north indicate that groundwater is not moving northward out of the aquifer, but is moving downward. The southern contoured local aquifer in Yucca Flat (section E-E' near well ER-3-2, pl. 2) portrays a U-shaped flow path. West of Yucca fault, hydraulic heads are highest in the northern part of this aquifer and decrease to the south. East of Yucca fault, hydraulic gradients reverse, with the highest heads being in the south and decreasing northward. Flow is to the south on the western side of Yucca fault, which directly or indirectly creates a hydraulic barrier, until reaching the southern part of the aquifer. Water then flows east across the fault and finally northward on the eastern side of the fault. Similar to the northern local aquifer in central Yucca Flat, head data in adjacent units indicate that lateral outward flow into hydrologic units to the north is limited. Most outflow from both aquifers likely is downward and controlled by geologic structures. Yucca fault is the probable structure hydraulically connecting the local alluvial-volcanic aquifers with the underlying regional carbonate aquifer. The connection may be through fault-induced secondary permeability or by faultinduced juxtaposition of carbonate and alluvial-volcanic rock (Bechtel Nevada, 2006). Where the alluvial-volcanic and carbonate aquifers are hydraulically connected by the fault, water is inferred to drain from the alluvial-volcanic aquifer into the carbonate aquifer, which has a lower hydraulic head (Winograd and Thordarson, 1975). The lowest hydraulic heads in the northern and southern alluvial-volcanic aquifers are 2,424 ft in well U E-2aa (2207 ft) and 2,391 ft in well TW-7, respectively. These heads are similar to heads in the regional carbonate aquifer at these two locations (pl. 4), suggesting some hydraulic connection between the local aquifer and the regional carbonate aquifer along the eastern side of Yucca Flat. If this connection exists, radionuclides in the alluvialvolcanic aquifers in Yucca Flat could migrate into the regional carbonate aquifer. Several wells open to the carbonate aquifer downgradient from one of these hydraulic lows in the local alluvial-volcanic aquifers would be needed to determine if radionuclides are migrating to the regional carbonate aquifer.

Two local alluvial-volcanic aquifers with hydraulic-head data are located south of Yucca Flat and west of Frenchman Flat (pl. 3). Wells open to the local alluvial-volcanic aquifer beneath Mid Valley have relatively low heads of 2,687 to $2,693 \mathrm{ft}$. On the basis of limited data, water in this aquifer is interpreted to be flowing southwestward towards the regional alluvial-volcanic aquifer in Jackass Flats (pl. 3). The second local aquifer lies in CP basin (pl. 3). Hydraulic heads of about $2,780 \mathrm{ft}$ in this aquifer are higher than heads in any of the nearby local alluvial-volcanic aquifers (pl. 3). This suggests that the aquifer is isolated from these nearby aquifers and stores local recharge from surrounding highlands. Wells WW-4 and WW-4A (pl. 1) have withdrawn about 5,800 acre-ft of water from this aquifer from 1983 to 2008 (U.S. Geological Survey, 2009), primarily for local supply in support of NTS operations. The response of the water levels over time in these 
wells (appendix 1) suggests most of the pumped water is being withdrawn from storage and that lateral inflows are likely limited. Wells open to the volcanic confining unit underlying Pluto Valley have high heads (about 4,000 ft), which are considered to be perched (Johnson and Ege, 1964).

The southernmost local alluvial-volcanic aquifer in the study area underlies Frenchman Flat (sections A-A' and E -E', pl. 2; pl. 3). Similar to Yucca Flat, hydraulic-head data are available in Frenchman Flat because of the many wells drilled and completed to support past underground testing (U.S. Department of Energy, 2000b). Heads in this aquifer are the lowest of any of the local alluvial-volcanic aquifers, ranging from 2,386 to 2,413 ft. Spatial variation in heads across the aquifer is small, and the corresponding horizontal hydraulic gradient is about $4 \mathrm{ft} / \mathrm{mi}$. Outflow from the aquifer is interpreted to be southeastward and downward into adjacent and underlying confining units, but the single contour is dashed due to uncertainty in the flow direction.

\section{Flow Systems}

Water in the regional alluvial-volcanic aquifer within the study area (pl. 3) flows to one of three groundwater flow systems: Oasis Valley, Alkali Flat-Furnace Creek Ranch, and Ash Meadows (Blankennagel and Weir, 1973; Winograd and Thordarson, 1975; Waddell and others, 1984; Laczniak and others, 1996). Two of these flow systems and their component tributary flow systems are shown on plate 5 . The third flow system, Ash Meadows, is predominantly made up of the regional carbonate aquifer and is shown where it occurs in the study area on plate 6 . The Belted Range tributary flow system, interpreted to be a small component tributary of the Ash Meadows flow system, includes alluvial-volcanic aquifer (pl. 5) and carbonate aquifer (pl. 6).

\section{Black Mountain Tributary Flow System}

The Black Mountain tributary flow system forms the northwestern branch of the Oasis Valley flow system (pl. 5). Most of the water in this system is assumed to originate from precipitation that infiltrates into alluvial and volcanic rocks north of the study area (Faunt, D'Agnese, and O'Brien, 2004, fig. D-2). This water flows into the mapped part of the aquifer as underflow across the northern boundary of the study area. Some water also enters the system locally as recharge in the area of Black Mountain (pl. 3). The general direction of flow within the Black Mountain tributary flow system is southward towards Oasis Valley and into the downgradient Oasis Valley flow system. The western boundary of the Black Mountain tributary flow system, an inferred northsouth divide between southerly flow to Oasis Valley and southwesterly flow to Sarcobatus Flat (ig. 1$)$, is nearly coincident with the western boundary of the study area. The eastern boundary of the Black Mountain tributary flow system is shared with the Pahute Mesa tributary flow system. This shared boundary is nearly coincident with the western extent of the Silent Canyon Caldera complex and is defined by the hydraulic-head discontinuity discussed earlier in the report (pl. 3). The predominant flow direction along this boundary in both tributary flow systems is interpreted to be parallel to the boundary; however, head gradients indicate that a minor amount of water probably moves across the eastern boundary of the Black Mountain tributary flow system into the Pahute Mesa tributary flow system.

\section{Pahute Mesa Tributary Flow System}

The Pahute Mesa tributary flow system forms the northeastern branch of the Oasis Valley flow system (pl. 5). This tributary flow system may receive water as underflow across the northern boundary of the study area, but much of the water flowing through the system probably is derived locally from recharge on Pahute and Rainier Mesas (pl. 3). As depicted schematically by flow arrows on plates 3 and 5 , large amounts of water are interpreted to flow through the Pahute Mesa tributary flow system as compared to the Black Mountain tributary flow system and other alluvialvolcanic flow systems on the NTS. Flow in the Pahute Mesa tributary flow system is dominantly southwest towards Oasis Valley and into the downgradient Oasis Valley flow system. The northeastern boundary of this tributary flow system is the eastern extent of the regional alluvial-volcanic aquifer. The southeastern boundary is shared with the Fortymile Wash and Crater Flat tributary flow systems and its exact location is uncertain. This shared boundary is defined by the potentiometric contours that separate more westerly flow paths towards Oasis Valley from more southerly flow paths toward the Amargosa Desert.

Uncertainty in the location of the boundary of the Pahute Mesa tributary flow system with the Fortymile Wash and Crater Flat tributary flow systems is caused largely by an absence of data beneath Timber Mountain. This gap in data leaves flow directions in the area uncertain. Additional subsurface hydrologic and geologic data are needed to determine if a divide exists, and if so, its location and whether it is caused by a groundwater mound from recharge of precipitation falling on the mountain, by the low permeability of intra-caldera rock, or by geologic structures associated with the formation and presence of the caldera.

\section{Oasis Valley Flow System}

The Oasis Valley flow system extends generally through the Oasis Valley area and begins where flow from the Black Mountain and Pahute Mesa tributary flow systems converges (pl. 5). Profiles of the flow system and its tributaries, oriented transverse to flow and along a flow path, are shown on sections $A-A^{\prime}$ and $C-C^{\prime}$ of plate 2 . The boundary between the two tributary flow systems and the Oasis Valley flow system 
is intended to portray the area where water from upgradient tributary flow systems mix. The western boundary of the Oasis Valley flow system is near the western boundary of the study area, but locally may extend several miles farther west. An estimated 6,000 acre-ft/yr of the water discharging at springs and seeps in Oasis Valley, plus an additional 80 acre-ft/yr of underflow into the downgradient Upper Amargosa tributary flow system (Reiner and others, 2002), must pass through the Oasis Valley flow system and its tributaries. The Pahute Mesa tributary flow system is believed to contribute the largest amount of water to the Oasis Valley flow system, with the Black Mountain system as a lesser secondary source. Minor amounts of water also may discharge to Oasis Valley from local carbonate aquifers (pl. 4).

The eastern extent of the Oasis Valley flow system and its tributaries, as depicted in plate 5 , differs significantly from that of the Oasis Valley subbasin shown in Waddell and others (1984) and Laczniak and others (1996). The Oasis Valley subbasin, as mapped by these authors, essentially excludes the Pahute Mesa tributary flow system shown on plate 5 from the Oasis Valley flow system, but the authors of both reports discuss uncertainties related to its possible inclusion. Numerical flow models from other studies also indicate a component of flow from eastern Pahute Mesa that does not flow to Oasis Valley but rather bypasses it to the east (U.S. Department of Energy, 1997a; Faunt, Blainey, and others, 2004; Ruskauff and others, 2006; Zhu and others, 2009).

The bulk of the water in the study area flowing beneath Pahute Mesa passes through Oasis Valley, as interpreted on plates 3 and 5, rather than flowing south into the Crater Flat tributary flow system. The implication of this conceptualization for radionuclide transport is that any water flowing beneath the historical testing area in Pahute Mesa ultimately will pass through Oasis Valley rather than moving southward toward the Yucca Mountain area and into the Crater Flat or Fortymile Wash tributary flow systems. An absence of hydraulic-head and subsurface data in the area of Timber Mountain creates uncertainty as to the precise location of the eastern boundary of the Oasis Valley flow system and the upgradient Pahute Mesa tributary flow system.

\section{Upper Amargosa Desert Tributary Flow System}

The Upper Amargosa Desert tributary flow system is one of three tributary systems composed of alluvial-volcanic aquifer that discharges into the Alkali Flat-Furnace Creek Ranch flow system (pl. 5). Most of the Upper Amargosa Desert tributary flow system is within the study area. The tributary flow system is believed to extend slightly westward beyond the study area boundary to include a small area generally defined as the remaining westward part of the Amargosa Desert. The system is bounded on the north and south by confining unit. Flow through the Upper Amargosa Desert tributary flow system is portrayed as being relatively small because the system is isolated from any upgradient aquifers and lacks any significant sources of local recharge (pls. 3 and 5). As conceptualized, some water enters the tributary flow system as underflow across its mapped extent along the western boundary of the study area. A small amount of water (about 80 acre-ft/yr as estimated by Reiner and others, 2002) also enters the system through a small alluvial channel in the Amargosa River south of Beatty. The source of this channeled groundwater is outflow from the Oasis Valley flow system that bypasses the Oasis Valley discharge area. Flow in the Upper Amargosa Desert tributary flow system primarily is southeastward into the Alkali Flat-Furnace Creek Ranch flow system.

\section{Crater Flat Tributary Flow System}

The Crater Flat tributary flow system is a second tributary to the Alkali Flat-Furnace Creek Ranch flow system (pl. 5). Flow within this tributary flow system is predominantly southward and is derived primarily from local recharge originating as precipitation on Timber Mountain and from highland areas in northern Yucca Mountain and Bare Mountain. The western boundary of this tributary flow system is Bare Mountain, where the alluvial-volcanic aquifer contacts confining unit composed of siliciclastic rocks. The northern boundary and its associated uncertainties are discussed in a previous paragraph describing the Pahute Mesa tributary flow system. The Crater Flat tributary flow system shares its eastern boundary with the western boundary of the Fortymile Wash tributary flow system. The precise location of this shared eastern boundary is uncertain because the head data used to develop local potentiometric contours are limited. The southern part of this eastern boundary coincides with a high-gradient area along the Solitario Canyon fault near Yucca Mountain (pl. 5). Near this high-gradient area, most of the groundwater within the tributary flow system is inferred to move southward parallel to the boundary, with some limited outward leakage across the boundary into the Fortymile Wash tributary flow system.

\section{Fortymile Wash Tributary Flow System}

The third tributary discharging to the Alkali Flat-Furnace Creek Ranch flow system is the Fortymile Wash tributary flow system (pl. 5). Groundwater within this tributary flow system originates as recharge from highlands near Rainier Mesa and from Timber Mountain, Shoshone Mountain, and other small highland areas north of Yucca Mountain. An additional documented source of local recharge is infiltration into the alluvial sediments in Fortymile Wash during intermittent 
streamflow events (Claassen, 1985; Savard, 1998). As portrayed by arrows on plate 5 , flow primarily is southward into the Alkali Flat-Furnace Creek Ranch flow system. Flow begins at Rainier Mesa, continues on through the highgradient area beneath northern Yucca Mountain, and then farther south under Fortymile Wash.

An alternative flow scenario to the one described above was presented by Fenelon and others (2008) because of uncertainties in the hydrogeologic framework for the Rainier Mesa and Shoshone Mountain area (National Security Technologies, LLC, 2007). In their alternative scenario, shallow carbonate aquifers underlying Rainier Mesa (portrayed as local carbonate aquifer on plate 4) contribute water to the Fortymile Wash tributary flow system. This alternative conceptualization assumes that carbonate rock underlying Rainier Mesa extends nearly unobstructed across the area mapped as Redrock Valley caldera. The validity of this scenario can not be determined without further investigations and drilling.

The eastern boundary of the Fortymile Wash tributary flow system is defined by the eastern extent of the alluvialvolcanic aquifer. The western and northwestern boundaries are uncertain and are defined by potentiometric contours that imply that the predominant flow direction is parallel to these boundaries. The potential for transport of radionuclides from tests in Rainier Mesa through the Fortymile Wash tributary flow system is discussed in Fenelon and others (2008).

\section{Alkali Flat-Furnace Creek Ranch Flow System}

The Alkali Flat-Furnace Creek Ranch flow system begins in the Amargosa Desert just southwest of the NTS (pl. 5). Similar to the Oasis Valley flow system, the boundary between the upgradient tributary flow systems and the Alkali Flat-Furnace Creek Ranch flow system is shown where flow within the tributary flow systems appears to converge. Vertical profiles of the flow system and its tributaries, oriented parallel to flow (section $D-D^{\prime}$ ) and transverse to flow (sections $A-A^{\prime}$ and $B-B^{\prime}$ ) are shown on plate 2. Only the upgradient part of the flow system lies within the study area. The entire flow system is much larger and extends southward across the boundary of the study area to include discharge areas in the Franklin Wells area, Franklin Lake playa (also known as Alkali Flat), and in central Death Valley near Furnace Creek Ranch (fig. 1). The flow system is supported by significant flow from the regional carbonate aquifer, (see section, "Rock Valley Tributary Flow System").

The extent of the Alkali Flat-Furnace Creek Ranch flow system and its tributaries, as depicted in plate 5 , is much less extensive than the Alkali Flat-Furnace Creek Ranch subbasin mapped in Laczniak and others (1996). As mapped on plate 5 , the flow system and its tributaries extend only as far north as Rainier Mesa and do not include any of the area beneath Pahute Mesa. Although the Fortymile Wash tributary flow system may contribute slightly more water to the Alkali Flat-Furnace Creek Ranch flow system than the other two tributaries, none of the three is overly dominant in terms of inflow. The combined flow from the three tributary flow systems is believed to be less than the estimated 6,000 acre-ft of annual groundwater discharge at Oasis Valley (Reiner and others, 2002). Most alluvial-volcanic groundwater within the Alkali Flat-Furnace Creek Ranch flow system that flows southward across the study area boundary probably discharges at Franklin Lake playa or the Franklin Wells area (fig. 1; Waddell and others, 1984, p. 62), which have about 1,300 acre-ft of annual groundwater discharge (Laczniak and others, 2001).

\section{Belted Range Tributary Flow System}

The one remaining tributary flow system delineated within the study area in the alluvial-volcanic aquifer is the Belted Range tributary flow system (pl. 5; section E-E', pl. 2). The conceptualization of groundwater flow within this tributary flow system is highly speculative because of the limited data available. Located in the northeastern corner of the study area, this tributary flow system is isolated from any of the other alluvial-volcanic aquifers. Because the Belted Range tributary flow system is surrounded by confining unit, flow into and through the system is likely to be small. As interpreted geologically, the alluvial-volcanic aquifer making up the Belted Range tributary flow system is underlain by regional carbonate aquifer throughout much of its extent. Water is assumed to be derived from local recharge west of the tributary flow system and from recharge entering volcanic rocks north of the study area and moving into the study area as underflow. Some diffuse or fault directed upflow from the underlying regional carbonate aquifer also is possible. The flow direction in this tributary flow system is poorly constrained by the data, but is believed to be east-southeast toward the Ash Meadows flow system (see "Flow Systems" discussion in "Carbonate Aquifer" section).

\section{Carbonate Aquifer}

The carbonate aquifer consists primarily of Paleozoic carbonate rock (figs. 2 and $\underline{3}$ ) and is mapped on plate 4 . As mapped, the aquifer includes both local and regional components referred to in this report as local and regional aquifers. The classification of a block of carbonate rock as either a regional or a local aquifer is based on the block's 
lateral and vertical extent and subsurface configuration. Regional carbonate aquifers are laterally extensive, contiguous blocks of carbonate rock that are hydraulically connected, and independently or together form part of a large flow system. Local carbonate aquifers are less extensive, disconnected blocks of carbonate rock that are stratigraphically or structurally isolated, hydraulically restricted, and generally drain only to adjacent confining units.

The regional carbonate aquifer is further subdivided into shallow and deep parts (pls. 2 and 4), although the deep part is not everywhere present (pl. 2). As mapped, the shallow part of the regional carbonate aquifer commonly is rimmed with a deep part of the aquifer near a caldera structure or along a dipping surface (pl. 4). These deep-carbonate fringe areas are considered hydraulically less active than the shallow parts of the aquifer and thus relatively unimportant to radionuclide transport; and therefore, are not mapped as part of any of the flow systems identified in this report.

\section{Nature and Extent}

The carbonate aquifer is mapped as a nearly continuous unit across the southeastern half the study area (pl. 4). Throughout this part of the study area, any carbonate rocks present are buried by Cenozoic volcanic and sedimentary rocks, covered by thrust sheets, or exposed at the land surface. Burial is most common beneath the major valleys, where the thickness of overlying Cenozoic deposits in areas such as Frenchman Flat can exceed 5,000 ft (pl. 4). Surface exposures of carbonate rock are most common in the mountain blocks in the eastern and southern parts of the study area, including the Halfpint and Specter Ranges (pl. 4). The interpretation of the continuous nature of the carbonate aquifer beneath Yucca Flat is based on drill holes that penetrate the aquifer (Cole, 1997; Cole and Cashman, 1999), the large thickness of the carbonate section, and similar hydraulic heads that suggest hydraulic continuity.

The mapped extents of the two blocks of carbonate aquifer in the northwestern and northeastern parts of the study area (pl. 4) are much less certain, primarily because of a lack of data. There are no outcrops or drill-hole intercepts of the carbonate rock near Black Mountain in the northwestern part of the study area or in Emigrant Valley (pl. 4). These blocks of carbonate aquifer are completely buried by Cenozoic volcanic and sedimentary rocks (northwest end of section $A-A^{\prime}$ and north end of section $E-E^{\prime}$, pl. 2) and their presence, extent, and thickness are defined solely on geologic relations observed in outcrops in surrounding uplands.

Interpretation of the extent and subsurface configuration of the carbonate aquifer in the study area is constrained by pre-Cenozoic thrust faults and by the occurrence of calderas (fig. 6; pl. 4). The carbonate aquifer is assumed entirely removed within caldera margins by activities associated with caldera formation and collapse. Pre-Cenozoic thrusts and
Cenozoic normal faults and strike-slip faults have disrupted the aquifer, and in places have created isolated, fault-bounded blocks of overlapping regional and local carbonate aquifer (fig. 6). Two major southeast-directed thrust faults exert significant control on the nature and extent of the carbonate aquifer in the study area (pl. 4). These two thrusts are the Belted Range thrust, mostly buried by Tertiary volcanic rocks at Rainier Mesa (northeast end of section D-D ', pl. 2), and the Specter Range thrust exposed in the Specter Range just south of the southern border of the NTS. A third controlling structure, the CP thrust, lies to the east and southeast of the Belted Range thrust (section B-B', pl. 2; pl. 4) and is interpreted as a back thrust with northwest-directed motion (Caskey and Schweikert, 1992; Trexler and others, 1996; Cole, 1997; Cole and Cashman, 1999).

Thrust faults are identified in outcrop at only a few locations and in a few drill holes within the study area. Occurrences include drill-hole data and limited outcrops at Rainier Mesa (Gibbons and others, 1963; Cole, 1997), drill-hole data from Yucca Flat (Cole, 1997; Cole and Cashman, 1999), outcrops in the Specter Range (Sargent and Stewart, 1971), and outcrops at Bare Mountain (Monsen and others, 1992). None of the thrusts are exposed continuously throughout the study area, but their presence in the subsurface is inferred on the basis of regional relations discussed in Cole and Cashman (1999). Within the NTS and surrounding area, the strike of the Belted Range and CP thrusts is shown to swing from north-northeasterly near Yucca Flat in the northeastern part of the NTS to easterly in the western and southern parts of the NTS (pl. 4; Snow, 1992; Cole and Cashman, 1999). The extent of the Specter Range thrust is limited within the study area, but is inferred to extend southwestward beyond the study area beneath the Amargosa Desert based on outcrops in the Specter Range (pl. 4). The Specter Range thrust appears to lose displacement to the northeast and die out near the western edge of Mercury Valley (Cole and Cashman, 1999).

The Belted Range and Specter Range thrusts, and locally the CP thrust, place confining unit composed of siliciclastic rock over the regional carbonate aquifer (Caskey and Schweikert, 1992; Cole and Cashman, 1999). These thrusts are similar to the many large-offset thrust faults in the southern Great Basin. Geologic cross sections that transect the study area (Sweetkind and others, 2001; Potter, Dickerson and others, 2002) use the consistent appearance of thrusted siliciclastic rock to infer that the soles of all the thrust faults are at a common stratigraphic level of detachment and splay upward from the same horizon (fig. 6). As a result, thrust faults within the study area juxtapose rocks (HSUs and SHUTs; figs. 2 and $\underline{3}$ ) of contrasting hydrologic properties and complicate groundwater flow patterns by acting as local barriers (Winograd and Thordarson, 1975; McKee and others, 1998). 


\section{North-South Cross Section}
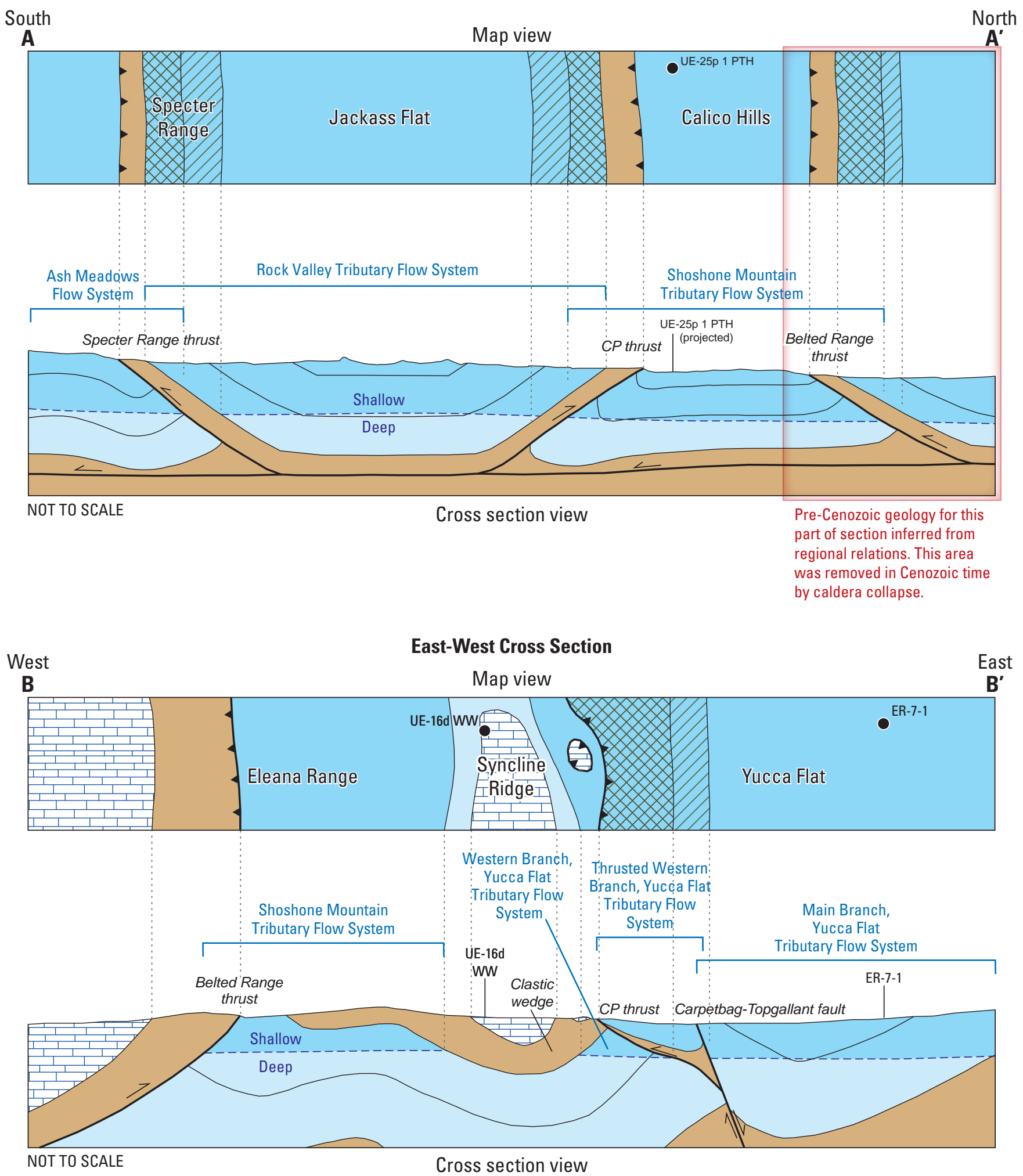

Figure 6. Generalized hydrogeologic cross sections for pre-Cenozoic rocks in the Nevada Test Site area, Nevada. 


\section{EXPLANATION}

\section{Regional carbonate aquifer}

Shallow part- Area where flow is most active and where top of saturation is within about 6,000 feet of land surface

Thrusted - Area where shallow aquifer is thrust over another shallow carbonate aquifer and the two aquifers are separated by siliciclastic rock

Thrusted-Area where shallow aquifer is thrust over a deep carbonate aquifer and the two aquifers are separated by siliciclastic rock

Deep part-Area where flow is assumed less active and where top of saturation is greater than about 6,000 feet below land surface

\begin{tabular}{c} 
Shallow \\
\hdashline----
\end{tabular} Approximate boundary between shallow and deep parts of regional carbonate aquifer

L ocal carbonate aquifer- Approximate extent of localized blocks of moderately permeable carbonate rock

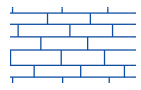

\section{Confining unit}

\section{Includes alluvial, volcanic and siliceous confining units}

_ـ_ Thrust fault_-Map trace; teeth on upthrown block

Thrust fault - On cross section; arrow on upthrown block shows direction of motion

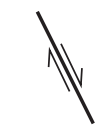

Normal fault- On cross section; arrows shows sense of offset

Form line_Showing general attitude of bedding in cross section view

C onstruction line-Showing corresponding features in map and cross section view
Sections portray generalized pre-Cenozoic geologic setting. Cenozoic geologic units, calderas, and structures, with the exception of the Carpetbag-Topgallant fault, are not shown.

Section A-A' modified from Sweetkind and others (2001), section H-27; Section B-B' modified from Sweetkind and others (2001), section H-22.

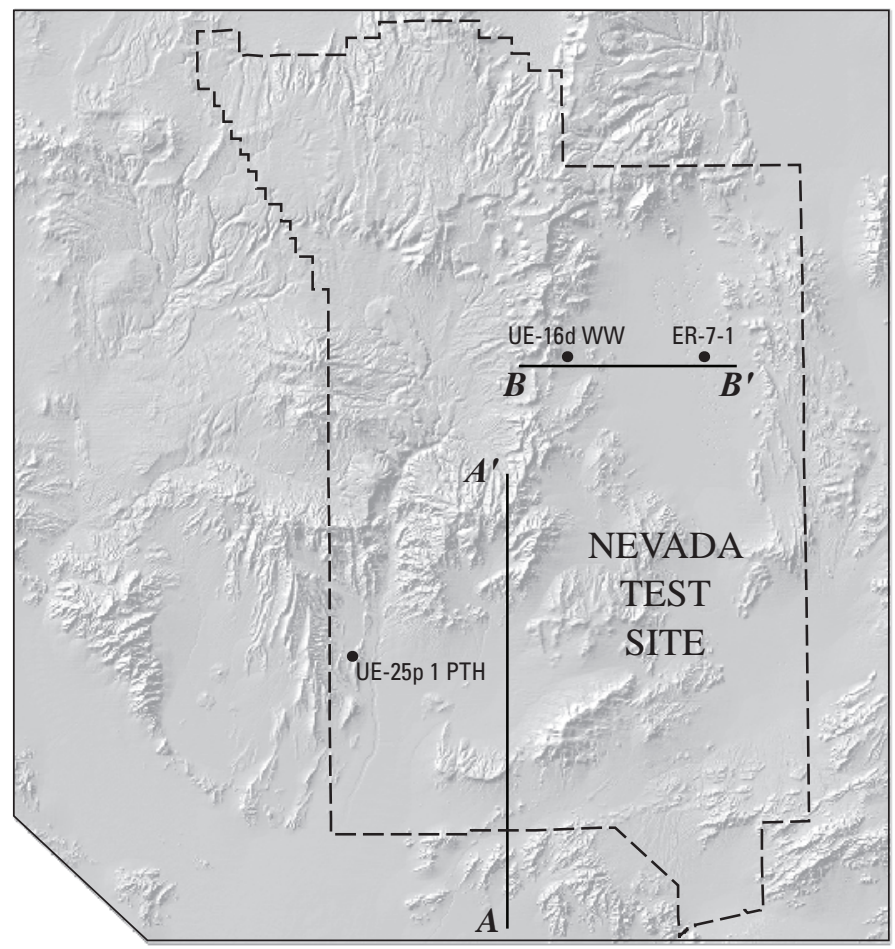

Figure 6. Generalized hydrogeologic cross sections for pre-Cenozoic rocks in the Nevada Test Site area, Nevada. - Continued 
The local occurrence of confining unit at the base of regional thrust sheets creates internal divides in the regional carbonate aquifer that can divert groundwater flow. Two generalized hydrogeologic cross sections (fig. 6) portray the interpreted subsurface geometry of pre-Cenozoic rocks along north-south (section A-A', fig. 6) and east-west (section B-B'; fig. 6) transects in the southern and eastern parts of the NTS area, respectively. In the southern part of the NTS area, the north-directed CP thrust and the south-directed Specter Range and Belted Range thrusts act as structural barriers and internally subdivide the regional carbonate aquifer by redirecting and constricting regional groundwater flow (section $A-A^{\prime}$, fig. 6). This internal compartmentalization of the regional carbonate aquifer is outlined below and discussed in more detail in later section, "Flow Systems."

A corridor of regional carbonate aquifer that underlies Shoshone Mountain and the northern part of Yucca Mountain (pl. 4) is bounded on the north and northwest by the Belted Range thrust (and subsequent Cenozoic calderas) and by confining unit at the base of the $\mathrm{CP}$ thrust on the southeast and south (section A-A', fig. 6). Borehole U E-25p 1 P TH penetrates Silurian carbonate rocks (Carr and others, 1986) that are interpreted to lie to the north of and beneath the CP thrust plate (Potter, Dickerson and others, 2002). The northdirected CP thrust overrides both shallow and deep parts of the regional carbonate aquifer, resulting in a complex map pattern in which the overridden regional carbonate aquifer and its associated tributary flow system is inferred to extend some distance southward beneath the CP thrust (section A-A', fig. 6; pl. 4). To the south of the CP thrust, a trough of relatively thick regional carbonate aquifer underlying Jackass Flats, Rock Valley, and Skull Mountain (pl. 4) is bounded by confining unit at the bases of the CP thrust on the north and the Specter Range thrust on the south (section A-A', fig. 6). A third compartment of the regional carbonate aquifer exists to the south of the Specter Range thrust (section A-A', fig. 6). On the basis of surficial geology and subsurface geologic relations, McKee and others (1998) suggested that the siliciclastic confining unit brought to the surface by the Specter Range thrust may divert groundwater moving southeast from Frenchman Flat to the south of the thrust plate.

In the Yucca Flat area, multiple regional and local carbonate aquifers are mapped on the basis of regional thrust faults, folds, and Cenozoic normal faults (section B-B', fig. 6). Similar to the geometry inferred in the southern part of the study area, a corridor of the regional carbonate aquifer that underlies the western part of Yucca Flat and the Eleana Range (pl. 4) is bounded on the west by the Belted Range thrust (and subsequent Cenozoic calderas) and by confining unit at the base of the $\mathrm{CP}$ thrust and by the Carpetbag-Topgallant fault on the east (section B-B', fig. 6). The regional carbonate surface in this corridor is internally disrupted by confining unit composed of Mississippian siliciclastic rocks that are folded by the synclinal downwarp at Syncline Ridge (section B-B', fig. 6). Post-Mississippian carbonate rocks overlie the confining unit in the core of the fold and form a local carbonate aquifer near borehole UE-16d WW (section B-B', fig. 6). The Carpetbag-Topgallant fault may hydraulically isolate the regional carbonate aquifer mapped in the upper plate of the CP thrust from regional carbonate aquifer mapped beneath the eastern half of Yucca Flat (section B-B', fig. 6). To the east and northeast of Yucca Flat, an anticlinal upwarp in the Halfpint Range (pl. 4) brings confining unit composed of siliciclastic rocks to the surface and has resulted in the removal of the regional carbonate aquifer by erosion.

Locally, the CP thrust climbs above the level of the confining unit composed of siliciclastic rock, carrying only Paleozoic carbonate rocks in its upper plate. Where this thrust lacks siliciclastic rock in its base and overrides the regional carbonate aquifer, such as near Mid Valley (pl. 4), a carbonateon-carbonate contact results - a configuration assumed to have minimal effect on regional groundwater flow. Where this thrust lacks siliciclastic rock in its base and overrides a confining unit, such as in Yucca Flat (pl. 4), the thrusted rock becomes isolated from any underlying aquifer and forms a small local carbonate aquifer as is shown just west of CP thrust and east of Syncline Ridge on section B-B' of fig. 6 and on plate 4. Northwest of Yucca Flat in the Rainier Mesa area, a complex stack of imbricate thrust slices extends about 2 to 4 mi east of the main Belted Range thrust; these slices place Paleozoic carbonate rock over the Upper Mississippian Chainman Shale, a siliciclastic rock that is a confining unit (Cole and Cashman, 1999). All these carbonate-rock slices are inferred to be hydraulically isolated, forming local carbonate aquifers.

Calderas within the study area have removed previously existing blocks of carbonate rock (section A-A', fig. 6; sections $A-A^{\prime}$ and $C-C^{\prime}$, pl. 2). Typically, calderas are underlain by large sub-volcanic granitic intrusions that are rooted deep within the subsurface. The lithologic discontinuity created by caldera formation and collapse across the steeply inclined structural margin can extend to depths of several miles. The rocks associated with sub-volcanic granitic intrusions typically are of lower permeability, and also may lower the permeability of rocks surrounding the calderas through contact metamorphism and by hydrothermal alteration. Thus, where calderas invade the subsurface, little or no carbonate aquifer is anticipated to exist at any depth. For similar reasons, the carbonate aquifer beneath the Gold Meadows stock at Rainier Mesa (pl. 4), the Climax stock area to the north of Yucca Flat (pl. 4), and the Wahmonie volcanic center west of Frenchman Flat (pl. 4) is inferred to be absent.

The magnitude of offset on many of the Cenozoic normal faults in the study area (generally less than 1,000 ft) is relatively minor when compared to the 6,000 to 10,000 -foot thickness of the carbonate aquifer. As such, offset on these faults typically place carbonate against carbonate, rather than juxtapose the carbonate aquifer against another less permeable 
rock (sections $A-A^{\prime}$ and $E-E$ ', pl. 2). Normal faults may be important locally where they are transverse to the flow direction or where they contain low-permeability clays in their cores. In contrast, large-magnitude normal offset along the Bullfrog Hills-Fluorspar Canyon detachment fault (pl. 4) has severely thinned and disrupted the carbonate aquifer such that only local fault-bounded slivers of local carbonate aquifer are inferred to exist beneath Oasis Valley (section C - ' $^{\prime}$, pl. 2; pl. 4; Fridrich and others, 2007). Large-magnitude normal offset in the northwestern part of the Amargosa Desert, to the southwest of Bare Mountain (pl. 4), has largely removed the regional carbonate aquifer in this area.

Seismically active faults and faults that are optimally oriented for failure with respect to the present-day stress field may be of special interest from a hydrologic standpoint. Barton and others (1995) used down-hole monitoring of in-situ stresses and fluid flow in fractured and faulted rock in three locations in Nevada and California to show that critically stressed fractures and faults have much higher permeability than those not oriented optimally for failure in the current stress field. Faunt (1997) analyzed in-situ stress measurements, earthquake focal mechanisms, and geologic evidence, to infer the likelihood of faults as conduits or barriers to flow near the NTS. Given the present-day stress field, where the mean orientation of the minimum horizontal stress is approximately northwest-southeast (Stock and others, 1985), Faunt (1997) suggested that faults in relative tension (north- to northeast-striking) would be conduits for flow, and those in relative compression (northwest-striking) would be barriers to flow. Ferrill and others (1999) proposed a similar situation for predominantly north-northeast-striking faults at Yucca Mountain. Potter, Sweetkind, and others (2002) mapped zones of young faults and clusters of natural seismicity to emphasize their potential hydrologic importance. One such zone encompasses the south-central part of the NTS where previous workers have used geologic characteristics to infer relatively high hydraulic conductivities. In this area, a broad potentiometric trough beneath the area between Yucca Flat, Frenchman Flat, and the Specter Range (pl. 4) is interpreted to be a highly fractured domain in the carbonate aquifer (Winograd and Thordarson, 1975; D'Agnese and others, 1997; Faunt, 1997). This inferred domain may be the result of deformation within a broad northeast-trending structural zone (Carr, 1984) that is dominated by northeast-striking faults that are in relative tension in the present-day stress field. Within the potentiometric trough, Winograd and Pearson (1976) have hypothesized "megascale channeling" through a highly transmissive corridor that is less than $3 \mathrm{mi}$ wide and extends from Mercury Valley southwest to Ash Meadows (fig. 1).

Large offset, northwest-trending, strike-slip faults, such as the Las Vegas Valley shear zone (pl. 4), have been interpreted to be local barriers to groundwater flow. This interpretation is based on the inferred presence of a core of fine-grained, relatively low-permeability gouge that is the locus of fault displacement, local juxtaposition of siliciclastic and carbonate rock, a rapid change in the potentiometric surface across these faults, and the occurrence of coincident springs (Winograd and Thordarson, 1975; Sweetkind and others, 2004). For similar reasons, northeast-trending strikeslip faults, such as the Cane Spring fault, the Rock Valley fault zone, and the Spotted Range fault zone, although roughly parallel to the general direction of regional groundwater (pl. 4), may alter flow paths by locally compartmentalizing the regional carbonate aquifer.

\section{Hydraulic Heads and Contours}

Hydraulic-head data from wells open to the carbonate aquifer generally are sparse in the study area, with the densest concentration of available data located on the NTS in Yucca Flat and Rainier Mesa (pl. 4). The paucity of head data for the carbonate aquifer can be traced to a lack of wells penetrating carbonate rock. Drilling into the carbonate aquifer has been infrequent, not because it lacks available water, but because of the excessive depths typically required to reach the aquifer's surface. The greater number of carbonate wells in the Yucca Flat and Rainier Mesa areas reflects primarily programmatic needs specific to underground testing and activities associated with environmental restoration.

The hydraulic heads in wells open to the carbonate aquifer are posted on plate 4 and tabulated in appendix 2 . Individual water-level measurements made in a well are listed in appendix 1. Heads in the carbonate rocks generally decrease southward across the study area and are highest in the northcentral and lowest in the southwestern parts of the study area (pl. 4). Hydraulic heads in carbonate rock throughout the study area range from highs of slightly more than $4,500 \mathrm{ft}$ beneath Emigrant Valley to lows of about 2,300 ft in the Amargosa Desert (pl. 4).

Only one hydraulic-head value is available for the two carbonate-rock blocks mapped as regional carbonate aquifer in the northern part of the study area near Black Mountain and beneath Kawich and Emigrant Valleys (pl. 4). The hydraulic head within the regional carbonate aquifer mapped in the northeastern block is estimated to be between about 4,300 and 4,600 ft; and in the northwestern block to be between 3,800 and $4,200 \mathrm{ft}$. These wide-ranging estimates take into consideration the northern and upland location of these areas, their assumed geologic and hydraulic separation from downgradient areas by confining unit, and hydraulic-head data in overlying aquifers and adjacent confining units (pls. 2, 3, and 4; appendix 2).

Hydraulic-head data are absent for the many small carbonate-rock blocks mapped as local or regional carbonate aquifers near Oasis Valley and the Bare Mountain area (pl. 4). The heads in these aquifers, although again highly uncertain, are estimated to be between 3,200 and 3,900 ft. This wideranging estimate is based on hydraulic-head data from nearby wells open to adjacent parts of alluvial-volcanic aquifer (pl. 3; appendix 2). A more precise estimate of the head in these hydraulically isolated small carbonate aquifers would require information on the aquifers vertical position relative to other 
saturated rock, its degree of confinement, and its potential to receive local recharge. However, more refined estimates have not been attempted, and are not considered relevant to the objectives of this report, primarily because of their inferred isolation.

The highest heads in carbonate-rock aquifers in the study area have been computed from water levels measured mostly in the carbonate-rock blocks mapped as local. Typical heads in these local aquifers are elevated by more than $500 \mathrm{ft}$ above heads in the more extensive regional carbonate aquifer mapped throughout the southeastern half of the study area. This head difference is assumed to be the result of hydraulic isolation imposed by confining unit that typically surrounds these local aquifers. Three local aquifers, two in western and one in northern Yucca Flat, have been pumped for local water supply or for scientific research directed at gaining a better understanding of radionuclide transport. The water was pumped from wells in boreholes UE-2ce, UE-16d WW, and UE-15d WW (pl. 4). Low to moderate water production from these three wells (U.S. Geological Survey, 2009) and their inferred hydraulic isolation supports the classification of these small, carbonate blocks as local aquifers. The isolation of the UE-2ce block is discussed in detail in Fenelon and others (2008, p. 25).

From a transport perspective, notable local carbonate aquifers include the small block of carbonate rock mapped west of Yucca Flat that was penetrated by borehole U E-2ce, and the broad, more extensive area of carbonate rock beneath Rainier Mesa that is present in boreholes ER-12-1, ER-12-3, E R-12-4, and TW-1 (section $D-D^{\prime}$, pl. 2; pl. 4). Underground nuclear devices have been detonated in unsaturated and perched saturated rock overlying each of these aquifers (U.S. Department of Energy, 1997b). At Rainier Mesa, nuclear devices were detonated in 62 tests conducted within bedded tuff that lay 1,000 or more feet above the local carbonate aquifer (Stoller-Navarro Joint Venture, 2008). In a test near borehole UE-2ce, a nuclear device was detonated about $200 \mathrm{ft}$ above the water table in unsaturated carbonate rock, and eight other devices were detonated nearby in unsaturated tuff and alluvium overlying the carbonate rock (U.S. Department of Energy, 1997b). Even under the most conservative assumption that radionuclides have entered or will enter these local carbonate aquifers, their transport into a more accessible downgradient environment would be severely hindered by thick confining unit that hydraulically isolates these local aquifers from the regional carbonate aquifer. Additional details about the limited potential for transport in these two local carbonate aquifers are given in Carle and others (2008) and Fenelon and others (2008).

Hydraulic heads computed from water-level measurements in the extensive block of regional carbonate aquifer mapped throughout the southeastern half of the study area vary by less than $200 \mathrm{ft}$ (pl. 4). The highest heads are 2,501 ft at well ER-16-1 (recompleted) beneath Shoshone Mountain and 2,483 ft at well U E-10 ITS 5 in northern Yucca Flat, and the lowest head is $2,314 \mathrm{ft}$ at well NC-EWDP-2D B in central Amargosa Valley. A few wells noted on plate 4, such as UE - 8 e (2470 ft) and U E -4ae (2457 ft) in Yucca Flat, are open not only to the regional carbonate aquifer but also to overlying saturated non-carbonate rock. Hydraulic heads in some of these wells are elevated with respect to other nearby carbonate heads and are assumed to be influenced by groundwater conditions in non-carbonate rock. The dominance of head by non-carbonate rock may suggest that the relatively thin intervals of carbonate rock open to these wells are void of any major fractures. These elevated heads are considered anomalous and were not contoured on plate 4 .

The potentiometric surface interpreted for the regional carbonate aquifer is shown by head contours on plate 4 . The interpretation is based on hydraulic heads computed from water levels measured in the carbonate aquifer, head data in adjacent non-carbonate saturated units, and internal and external geologic structures, such as thrust faults and fault zones, believed to control flow. Contours are drawn only in areas where geologic information and hydraulic-head data are adequate to make a plausible interpretation of the potentiometric surface at the scale of the map in the plate. The potentiometric surface within local carbonate aquifers and the northern blocks of regional carbonate aquifer are not contoured because of a lack of geologic or hydrologic data, and in the case of the local carbonate aquifers, because of their limited areal extent. Available data generally restricts contouring to the "shallow part" of the regional carbonate aquifer mapped in the southeastern half of the study area (pl. 4). Confidence in the contoured interpretation varies and is dependent on the geologic certainty and the number and distribution of available head values. The areas of highest confidence are centered on Yucca and Frenchman Flats.

The hydraulic gradient (the change in hydraulic head over distance), as defined by the contours shown on plate 4 , provides a conceptual description of groundwater flow within the regional carbonate aquifer. This gradient-driven conceptualization is portrayed by generalized flow arrows on plate 4 . The arrows shown within the regional carbonate aquifer indicate the primary flow direction; and their size indicates the relative amount of flow through the aquifer. The small arrows positioned along the outer boundary of the aquifer identify areas of likely lateral inflow or outflow.

Horizontal hydraulic gradients in the contoured block of regional carbonate aquifer throughout the southeastern half of the study area are low, seldom exceeding $5 \mathrm{ft} / \mathrm{mi}$ and more typically less than $1 \mathrm{ft} / \mathrm{mi}$. Gradients exceed $5 \mathrm{ft} / \mathrm{mi}$ along the margin of the aquifer where some recharge occurs and generally decrease toward the center of the aquifer and southwestward. The persistently low gradient across most of the contoured part of the regional carbonate aquifer is indicative of high aquifer permeability, very low flow rates, or a combination thereof.

The low hydraulic gradient indicated by the contours mapped throughout much of the southeastern part of the regional carbonate aquifer has been recognized by previous investigators and has been interpreted to be a highly 
transmissive corridor (Winograd and Thordarson, 1975; Winograd and Pearson, 1976). The location of the lowgradient area generally coincides with a mapped zone of young faults and clusters of natural seismicity in the southcentral part of the NTS (Potter, Sweetkind, and others, 2002) and also coincides with a broad northeast-trending structural zone (Carr, 1984) that is dominated by northeast-striking faults, such as the Rock Valley fault zone and Cane Spring fault (pl. 4). These faults are in relative tension in the presentday stress field and therefore have been inferred to be highly transmissive (Faunt, 1997; Potter, Sweetkind, and others, 2002).

Locally high horizontal gradients of up to about $20 \mathrm{ft} / \mathrm{mi}$ occur in Yucca Flat along the aquifer's northern boundary and in the southwestern corner of the study area along U.S. Highway 95 near Amargosa Valley, Nev. The highest local gradient, about $75 \mathrm{ft} / \mathrm{mi}$, is in the southeastern corner of the study area, southeast of Mercury, Nev. The high gradient along the northern edge of Yucca Flat is attributed to limited inflow through adjacent low-permeability rock and to minor amounts of mountain-front recharge to nearsurface carbonate rock from highlands that flank Yucca Flat to the west and north. Evidence for local recharge into these carbonate rocks is given in Fenelon and others (2008) and is supported by measured water-level rises in wells UE-10j (2232-2297 ft) and WW-2 (3422 ft) that coincide with wetter periods (pl. 4; appendix 1). The high gradient in the southeastern corner of the study area is attributed to lateral inflow through adjacent carbonate rock and through less permeable non-carbonate rock that is recharged by precipitation falling on the nearby Spring Mountains (south of study area, fig. 1). This high gradient also may be influenced by impedance imposed on northward inflow by generally eastwest trending faults associated with the Las Vegas shear zone and the Spotted Range fault zone (Winograd and Thordarson, 1975; Sweetkind and others, 2004).

The hydraulic gradient near Amargosa Valley, Nev. in the southwestern corner of the study area is attributed to flow impedance imposed by the Highway 95 fault and other proximal faulting in the area (Sweetkind and others, 2004). The inferred barrier effect of these faults is evidenced by the occurrence of ancient springs that formed the paleospring deposits found in the southern Crater Flat area (Quade and others, 1995) and is discussed in more detail in section, "Rock Valley Tributary Flow System."

Groundwater flow in the carbonate aquifer, as inferred from the geology, hydraulic heads, contours, gradients, and flow arrows shown on plate 4 , generally is toward discharge areas south and west of the study area (fig. 1). Water originating as recharge in highland areas internal and external to the study area infiltrates directly into the carbonate aquifer or enters indirectly as groundwater flow through adjacent geologic units. Aquifer inflows, as portrayed on plate 4, includes leakage along lateral boundaries from rocks that make up the highland areas in the north-central part of study area. Major inflows of groundwater occur across the southern half of the eastern study area boundary through carbonate rocks that extend outward to the east. Additional inflows occur across the southern study area boundary near Indian Springs Valley through carbonate rocks that extend outward to the south. Vertical gradients between contoured potentiometric surfaces in the carbonate and the alluvial-volcanic aquifers (pl. 3) generally indicate local leakage to the carbonate aquifer from above, across typically less permeable rocks that overlie the regional carbonate aquifer (pl. 2). Vertical flow is inferred only in two areas to be upward out of the regional carbonate aquifer. One area is in the northern part of Yucca Mountain near well UE-25p 1 PTH, where the difference between the contoured potentiometric surfaces in the alluvial-volcanic and carbonate aquifers indicate upward flow (section B-B', pl. 2). Upward flow in this area is consistent with the head estimates made in carbonate- and volcanic-rock sections penetrated during the drilling of well UE-25p 1 PTH (Craig and Robison, 1984). Although hydraulic-head data are lacking, another area of inferred upward flow between the alluvial-volcanic and carbonate aquifers is in eastern Emigrant Valley, west of Groom Lake (fig. 1). The potential for upward flow in the Groom Lake area is discussed in section, "Belted Range and Sarcobatus Flat Tributary Flow Systems.” The local geology of these two areas indicates that although flow is inferred to be upward, it is likely to be impeded by intervening confining unit.

Once in the carbonate aquifer, water moves toward areas of progressively lower hydraulic head usually in areas with limited recharge, such as large topographic valleys, or coincident with permeable geologic structures until ultimately reaching a point of discharge. The interpretation presented in this report, although generally consistent with those established in previous studies (Winograd and Thordarson, 1975; Waddell and others, 1984; Laczniak and others, 1996), does differ at the local scale. To help highlight those concepts of this interpretation most imperative to groundwater flow and transport, and to better illustrate differences with previous conceptualizations, the regional carbonate aquifer is subdivided into flow systems and their tributary components (pl. 6).

\section{Flow Systems}

Any movement of nuclear test-generated contaminants within the regional carbonate aquifer depends on the rate and direction of groundwater flow. Flow directions, based on the contoured potentiometric surface of the carbonate aquifer (pl. 4), are used to delineate the flow systems within the regional carbonate aquifer. These flow systems and their tributary components define the general path along which water moves from areas of recharge into areas of discharge. 
Flow systems and tributary flow systems delineated within the regional carbonate aquifer are shown for the study area on plate 6 . These flow systems exclude local carbonate aquifers and include only the shallow part of the regional carbonate aquifer (pl. 4). One flow system and six tributary flow systems are delineated within the study area (pl. 6): the Ash Meadows flow system and the Shoshone Mountain, Yucca Flat, Rock Valley, and Spring Mountains tributary flow systems in the southeastern half of the study area; and the Belted Range and Sarcobatus Flat tributary flow systems in the northeastern and northwestern parts of the study area, respectively. The primary flow direction and relative amount of groundwater moving through each flow system are illustrated by flow arrows on plate 6 .

The following paragraphs describe groundwater flow in each of the flow and tributary flow systems delineated on plate 6. Descriptions include a general discussion of their extent; inflow, outflow, and throughflow; and the geology controlling both internal and external flow. Taken together, these flow and tributary flow systems define the different flow paths that a contaminant could follow once in the regional carbonate aquifer. Inherent in their delineation are uncertainties that can confound the interpretation of groundwater flow. These uncertainties have implications for contaminant transport and most often result simply from a lack of local data. The most relevant uncertainties and their implications are discussed throughout the section, as are some suggestions for additional data collection focused specifically on uncertainty reduction.

Nearly all groundwater in the regional carbonate aquifer ultimately flows out of the study area (pls. 4 and 6). Destinations for this outflow are one of five general areas of groundwater discharge downgradient of the NTS (fig. 1): Ash Meadows; Franklin Lake playa (also known as Alkali Flat); Franklin Wells; central Death Valley near Furnace Creek Ranch; or Sarcobatus Flat (Winograd and Thordarson, 1975; Waddell and others, 1984; Laczniak and others, 1996). Within the study area, the Ash Meadows flow system transmits the largest amount of groundwater through regional carbonate aquifer (pl. 6). Laczniak and others (2001, table 10) estimate its discharge, primarily from regional springs at Ash Meadows south of the study area (fig. 1), to be about 18,000 acre-ft, with the recognition of some additional minor underflow into downgradient flow systems.

\section{Ash Meadows Flow System}

The Ash Meadows flow system, as shown on plate 6, includes regional carbonate aquifer mapped in the southeastern part of the study area. The flow system is presumed to extend outward from the study area's eastern and southern boundaries. As mapped, the Ash Meadows flow system is isolated from the more northern Rock Valley tributary flow system by confining unit present in the base of the upper plate of the Specter Range thrust (section A-A', fig. 6; pls. 4 and 6). Some limited lateral flow across the thrust plate is expected but the direction of flow, whether into or out of the Ash Meadows flow system, is uncertain. This directional uncertainty is caused by the lack of any local carbonate head data that would allow for the calculation of the hydraulic gradient across these two flow systems.

Most water within the Ash Meadows flow system originates from tributary flow systems both internal and external to the study area. A small amount of additional water also enters the flow system vertically from above, where the regional carbonate aquifer is overlain locally by confining unit. The largest component of inflow enters the flow system from the east through an adjacent part of the regional carbonate aquifer that extends outward across the eastern boundary of the study area (Laczniak and others, 1996, pl. 1). A minor amount of this eastern inflow may be contributed by the Belted Range tributary flow system, mapped in the northeastern part of the study area. The other large inflow component is contributed by the Spring Mountains tributary flow system (pl. 6) through a block of carbonate rock that extends south and southeast into the nearby Spring Mountains (fig. 1). A small amount of groundwater flows into the Ash Meadows flow system internally from within the study area through regional carbonate aquifer that makes up the Yucca Flat and Shoshone Mountain tributary flow systems. The conceptualization of flow, as portrayed in plate 6 , is that nearly all water discharging from the Ash Meadows flow system moves through the section of regional carbonate aquifer mapped in the study area.

\section{Spring Mountains Tributary Flow System}

The Spring Mountains tributary flow system is a southern tributary of the Ash Meadows flow system (pl. 6). As envisioned in this report, the tributary flow system includes not only the mapped block of carbonate in the very southeastern corner of the study area but an extension of this block south through Indian Springs Valley into the Spring Mountains and east into Clark County, Nev. to include Indian Springs, Nev. (fig. 1). The mapped internal boundary between the Spring Mountains tributary flow system and Ash Meadows flow system, nearly coincident with the Spotted Range fault zone (pl. 6), represents the general area where water originating from the Spring Mountains merges with the Ash Meadows flow system. The tributary flow system includes an area of groundwater discharge centered about a series of springs fed by water from the carbonate aquifer located east of the study area near Indian Springs, Nev. (Winograd and Thordarson, 1975, p. C67). Additional detail on groundwater flow through this section of the carbonate aquifer is given in Winograd and Thordarson (1975).

\section{Shoshone Mountain Tributary Flow System}

The Shoshone Mountain tributary flow system is centered at about the middle of the study area and includes the block of regional carbonate aquifer underlying Shoshone Mountain and the Eleana Range (pl. 6). The tributary flow system extends 
eastward into Mid Valley and westward to include carbonate rock beneath east-central Yucca Mountain encountered at well UE-25p 1 PTH. The tributary flow system is bounded from above and laterally throughout much of its extent by confining unit (sections B-B' and D-D', pl. 2) and is terminated on the south by confining unit in the base of the upper plate of the CP thrust (section A-A', fig. 6; section D-D', pl. 2; pl. 4). The Shoshone Mountain tributary flow system joins with the Yucca Flat tributary flow system through an eastward extension of the regional carbonate aquifer in the area of Mid Valley (pl. 6).

Groundwater inflow to the Shoshone Mountain tributary flow system is limited to leakage moving across confining unit. Leakage likely occurs laterally across contacts with the confining unit in the northern half of the flow system (pls. 4 and 6). Some vertical leakage also may occur across intervening confining unit that separates the regional carbonate aquifer of the Shoshone Mountain tributary flow system from local carbonate aquifers north and south of the Redrock Valley caldera (sections A-A' and D-D', pl. 2; pl. 4). The hydraulic separation of the regional carbonate aquifer in the Shoshone Mountain tributary flow system from overlying local carbonate aquifers is supported by the large difference (greater than 1,000 ft) in hydraulic heads computed from water levels. Vertical inflow elsewhere throughout the flow system, including areas overlain by the alluvial-volcanic aquifer (pl. 3), also is believed to be minor because any inflow first must pass through intervening confining unit (sections $A-A^{\prime}$, $B-B^{\prime}$ and $D-D^{\prime}$, pl. 2). Contours of the potentiometric surface within the Shoshone Mountain tributary flow system are based solely on three points, all of which are located in the southern half of the tributary flow system (pl. 4). In addition to having limited head data and owing to the complexity of the subsurface geology, uncertainties in the value of the posted heads are noteworthy. These uncertainties include potential errors in corrections made for hole deviation at borehole ER-16-1 and for temperature at well UE-25p 1 PTH (pl. 4; appendix 2). The representativeness of the hydraulic head posted for well UE -25a 3, as it relates to the regional carbonate aquifer, also can be questioned because (1) the carbonate rock open to the well is marbleized and (2) the well also is open to a significant thickness of overlying confining unit (pl. 4; appendix 3). Even with these uncertainties, the basic premise of the conceptualization presented on plates 4 and 6 would not be altered significantly.

Groundwater entering the Shoshone Mountain tributary flow system from the north generally flows southward. The bulk of the outflow occurs through the regional carbonate aquifer across its eastern boundary with the Yucca Flat tributary flow system (pl. 6). This inferred southern flow path is constrained primarily by the interpreted geology. Water entering the regional carbonate aquifer from the west or north, upgradient of its confluence with the Yucca Flat tributary flow system, is forced southward by the presence of a thick section of confining unit referred to in Fenelon and others (2008) as the "clastic wedge." This confining unit, underlain only by deep regional carbonate aquifer in the area of Syncline Ridge (pl. 4), is shown on section A-A' of plate 2 just east of borehole ER-16-1 and on section B-B' in fig. 6 . The wedge divides the shallow part of the regional carbonate aquifer into two north-south trending pieces of regional carbonate aquifer - the western piece is part of the Shoshone Mountain tributary flow system, and the eastern piece is part of the Yucca Flat tributary flow system. Although the wedge obstructs eastward flow in the shallow part of the carbonate aquifer, some flow through the deep part of the carbonate aquifer across the area beneath the wedge into the Yucca Flat tributary flow system is likely.

Potentiometric contours and flow arrows on plate 4 in the northern part of the Shoshone Mountain tributary flow system portray a relatively low hydraulic gradient and a limited amount of flow through the aquifer. In part, these conditions exist because inflows from the north are assumed minimal. As mapped, the Belted Range and the Shoshone Mountain tributary flow systems shown on plate 6 are separated by a thick section of confining unit that overlies the thin east-west strip of deep carbonate aquifer shown on plate 4 near borehole U SGS-Shot Hole in the area of Aqueduct Mesa (also see well USGS-Shot Hole in appendix 3). The presence of confining unit between these two tributary flow systems is inferred to hydraulically isolate the two blocks of shallow carbonate aquifer that form the upgradient parts of each of the flow systems. This inferred hydrologic divide is reinforced by local highland recharge in the areas of Rainier Mesa and the Belted Range (pl. 3). Contrarily, a less restrictive separation between the two carbonate-rock blocks likely would result in a much smaller difference in heads than is portrayed on plate 4 in the upgradient parts of the Belted Range and Shoshone Mountain tributary flow systems. The degree of the hydraulic separation between these two carbonate-rock blocks will remain uncertain without additional head data from wells penetrating carbonate rock in the northern part of the Shoshone Mountain and southern part of the Belted Range tributary flow systems.

A small amount of groundwater in the Shoshone Mountain tributary flow system southwest of its confluence with the Yucca Flat tributary flow system moves southward, ultimately encountering confining unit contained in base of the upper plate of the CP thrust (section A-A', fig. 6). The base of this thrust plate forms the southern boundary of the tributary flow system and blocks flow from moving southward into the Rock Valley tributary flow system (pls. 4 and 6). Water encountering the confining unit is forced eastward toward the Yucca Flat tributary flow system. This blockage may be the cause of the aforementioned upward gradient between the regional carbonate aquifer and the overlying alluvial-volcanic aquifer near well UE-25p 1 PTH and may help sustain the generally flat gradient throughout the southwestern part of the Shoshone Mountain tributary flow system. As portrayed, this southwestern wing of the Shoshone Mountain tributary flow system is fairly stagnant and contributes only minimal inflow to the Yucca Flat tributary flow system (pl. 6). 


\section{Yucca Flat Tributary Flow System}

The Yucca Flat tributary flow system, which lies entirely within the study area, extends southward through Yucca Flat and CP Basin, and into the northwestern part of Frenchman Flat (pl. 6). In the Frenchman Flat area, some of the water moving through the flow system discharges into the Ash Meadows flow system, whereas the remaining water continues southwestward into Rock Valley and discharges into the Rock Valley tributary flow system (pl. 6). Within Yucca Flat, the Yucca Flat tributary flow system is bounded on the west by Syncline Ridge, on the north by Quartzite Ridge and Rhyolite Hills, and on the northeast by the Halfpint Range (pl. 6). Southwest of Yucca Flat in Mid Valley, the tributary system joins with and is fed by water from the Shoshone Mountain tributary flow system. Some minor amount of flow may occur across the eastern boundary of the tributary flow system's common boundary with the Ash Meadows flow system (pl. 6).

Elsewhere within the Yucca Flat tributary flow system, inflow to the regional carbonate aquifer is constrained primarily to areas where the aquifer is in contact with confining unit. Limited lateral inflow across confining unit occurs along the northeastern and northwestern boundaries of the tributary flow system. The inference of only limited lateral inflow from across these low permeability rocks is consistent with the steep hydraulic-head gradient found throughout their extent.

Vertical hydraulic gradients between overlying saturated rock of Cenozoic age and the regional carbonate aquifer of the Yucca Flat tributary flow system generally indicate downward flow potential. Any groundwater moving downward into the carbonate aquifer through the confining unit that overlies the aquifer nearly throughout its entire extent is expected to be limited by the impeding nature of the confining unit. Some of this vertical leakage is likely to originate from overlying alluvial-volcanic aquifers in Yucca and Frenchman Flats, CP Basin, and Mid and Pluto Valleys (pl. 3). Vertical leakage occurs over a broad area as diffuse inflow across the intervening confining unit or in a more focused form through fairly narrow fault zones that cross cut the confining unit and hydraulically connect the regional carbonate aquifer to the overlying alluvial-volcanic aquifer (sections $A-A^{\prime}$ and $E-E^{\prime}$, pl. 2; pl. 3; Winograd and Thordarson, 1975).

Recent hydrostratigraphic framework models (Bechtel Nevada, 2006) portray a thin strip of continuous carbonate rock, coincident with the extension of the Carpetbag-Topgallant fault near borehole U -15k Test Hole, that connects Yucca Flat and Emigrant Valley. Although it could be argued that this inferred carbonate connection, if saturated, hydraulically connects the upgradient Belted Range tributary flow system with the Yucca Flat tributary flow system, the large decrease in hydraulic head of about 2,000 ft (pl. 4) across the systems indicates otherwise. In addition to a high hydraulic gradient between these two flow systems, other indirect evidence contradicts any significant inflow from the Belted Range tributary flow system through this potential carbonate connection. This evidence includes (1) the nearby presence of the Climax Stock-an igneous granitic intrusive rock that has thermally altered the adjacent rock and decreased its hydraulic conductivity, (2) the geology at nearby borehole E R-8-1, which penetrated only saturated granitic rock (confining unit) and no saturated carbonate rock (section $E-E^{\prime}$, pl. 2; pl. 4; appendix 3), and (3) heads in wells UE-15d WW, U-15k Test Hole, and the ME wells near Climax Mine (pl. 4; appendix 2), which indicate a consistent high gradient across the saturated rock that separates the two flow systems.

The Yucca Flat tributary flow system itself is made up of three branches generally delineated on the basis of internal geologic structures (pl. 6). This multi-branch flow system consists of a main branch, which makes up the eastern twothirds of the tributary flow system, and two western branches, which feed the main branch. The two western branches are referred to as the "western" and "thrusted-western" branches (section B-B', fig. 6). The main branch, which includes the eastern two-thirds of Yucca Flat, terminates on the west against the north-south striking Carpetbag-Topgallant fault (section B-B', fig. 6; pl. 6). As portrayed, the main branch is separated from the western branches either by (1) confining unit that was thrusted over carbonate rock, (2) a thin strip of deep carbonate rock coincident with the Carpetbag-Topgallant fault, (3) the Carpetbag-Topgallant fault itself, or (4) some combination thereof (section B-B', fig. 6; pls. 4 and 6). Where the thrusted-western branch overlies the western branch they are separated by a confining unit that lies at the base of the CP thrust plate (section B-B', fig. 6; pls. 4 and 6).

Groundwater generally flows southward through each of the three branches of the Yucca Flat tributary flow system and converges with water flowing eastward from the Shoshone Mountain tributary flow system, prior to diverging and flowing out into either the Rock Valley tributary flow system or Ash Meadows flow system. Hydraulic-head data, particularly within the western and thrusted-western branches of the Yucca Flat tributary flow system, are lacking; and the interpreted potentiometric surface is based primarily on head data in adjacent rock.

The potentiometric surface in the western branch is portrayed by a single 2,450-ft contour line that trends diagonally southwest to northeast (pl. 4). Groundwater flow is assumed dominantly south-southeastward, with some limited eastward leakage across the Carpetbag-Topgallant fault through shallow or deep carbonate rock or confining unit. Southward flowing groundwater merges with water flowing in the main branch of the Yucca Flat tributary flow system south of borehole UE-1h. In this general area, the east-bounding confining unit that makes up the base of the CP thrust thins and the two shallow parts of the regional carbonate aquifer become laterally connected (pl. 4). Hydraulic heads throughout the northern part of the western branch are unknown and the inferred hydraulic isolation by the CP thrust and Carpetbag-Topgallant fault is highly conjectural; these uncertainties will remain until new wells are drilled in the area. 
The potentiometric surface in the thrusted-western branch of the Yucca Flat tributary flow system is portrayed by a single 2,500-ft contour line (pl. 4). The location of this lone contour is highly uncertain and is constrained downgradient only by the interpretation of hydraulic head in the western branch of the Yucca Flat tributary flow system and upgradient by drilling depths of known dry boreholes ( $\mathrm{U}-2 \mathrm{ct}$, UE-4ac, and U E-4ae; pl. 4; appendixes 1 and 2). Downward groundwater flow into the underlying western branch is restricted by intervening confining unit associated with the base of the CP thrust plate (section B-B', fig. 6). Groundwater flowing through the northern part of the thrusted-western branch is diverted southward by confining unit in the base of the CP thrust plate along its western boundary and by the Carpetbag-Topgallant fault along its eastern boundary, which juxtaposes both non-carbonate and carbonate rocks east of the fault against carbonate rock in the thrust plate (section B-B', fig. 6; pl. 6). The thrusted-western branch joins with the western branch of the Yucca Flat tributary flow system in the general area between boreholes UE-1d and UE-1h, where the confining unit that makes up the base of the CP thrust plate is missing and thrusted carbonate rocks are in direct contact with carbonate rocks that lie beneath the CP thrust (pl. 4). This interpretation recognizes some eastward leakage across the east-bounding Carpetbag-Topgallant fault into juxtaposed parts of the alluvial-volcanic and carbonate aquifers and confining unit (pls. 3 and 4).

The location of the sole potentiometric contour and the inferred hydraulic gradients in the thrusted-western branch of the Yucca Flat tributary flow system are uncertain because of the paucity of hydraulic-head data. Consideration of these uncertainties, as related to radionuclide transport, is warranted because of the many underground nuclear tests conducted in the western part of Area 2 of the NTS; one of these tests (near borehole UE-2ce) had a device detonated in unsaturated carbonate rock (Carle and others, 2008). Notable concerns regarding the thrusted-western branch, as delineated in plate 6 , include uncertainties in (1) the conceptualized isolation of the local carbonate aquifer centered about borehole UE-2ce from the branch, (2) the assumed continuity of the carbonate rock across the branch's mapped extent, (3) the extent and continuity of siliceous rock in the base of the upper plate of the CP thrust, (4) the inclusion of the branch as part of the Yucca Flat tributary flow system rather than an isolated local aquifer, and (5) the inferred hydraulic separation of the branch from the main branch by the Carpetbag-Topgallant fault. Any refinement or advancement of these hydrologic concepts will require additional subsurface data on the local geology and hydrology of the area.

The potentiometric surface in the main branch of the Yucca Flat tributary flow system is defined by contours that range from 2,380 to 2,500 ft. These contours are interpreted from a fairly dense distribution of hydraulic-head data in the northern (upgradient) part of the branch and lesser data in the southern part (pl. 4). Flow in the upgradient part of the main branch has a regional component of flow to the south superimposed locally by inward flow toward the branch's central axis (pls. 4 and 6). Groundwater flow within this branch is of particular importance because most of the 671 underground nuclear tests in Yucca Flat and Frenchman Flat (Laczniak and others, 1996, table 4) were conducted within its extent. Two tests in NTS Area 10 and one in Area 7, along the outer margin of the main branch in the northern part of Yucca Flat, had devices detonated in unsaturated carbonate rock. The Bourbon test, conducted in Area 7 just northwest of borehole U E-7nS, had its device detonated within $150 \mathrm{ft}$ of the water table and its cavity is predicted to intersect saturated carbonate rock at the top of the regional carbonate aquifer (Carle and others, 2008).

Inflow to the regional carbonate aquifer in the Yucca Flat area is limited by the low permeability of the surrounding confining unit through which most of the inflow must pass. Inflows from the west slightly elevate heads along the western margin of the main branch of the Yucca Flat tributary flow system. These inflows likely originate from water recharged in highlands to the west and north that leaks across the Carpetbag-Topgallant fault through confining unit and/ or through local faulted contacts with saturated carbonate or volcanic rock. These slightly elevated heads in the area between the north-south trending Carpetbag-Topgallant and Yucca faults create an eastward gradient toward the center of the Yucca Flat basin. These local variations and noted anomalies in the heads within this fault-bounded block (pl. 4) are attributed either to minor hydraulic discontinuities caused by the local faulting or to hydraulic influences from noncarbonate units penetrated by wells completed in multiple saturated units. Inflows from the west, north, and northeast all converge to form a major southward flow path through the main branch of the Yucca Flat tributary flow system centered east of the Yucca fault (pls. 4 and 6).

Groundwater moving south in the main branch of the Yucca Flat tributary flow system into Frenchman Flat converges with outflow from the two western tributary branches and the Shoshone Mountain tributary flow system. In the area of the convergence, flow in the regional carbonate aquifer is complicated by local geologic features that include a small area of intrusive rocks of the Wahmonie volcanic center (Sweetkind and others, 2001) and faulting associated with the CP thrust and its various imbricates (pls. 4 and 6). Although strewn with structures that are potential obstacles to flow, particularly beneath Mid Valley and CP Basin (pl. 4), a continuous carbonate aquifer is inferred where thrusted and in-place carbonate rock are in local contact. The hydraulic connection across the various structures is highly conjectural and is based on very limited carbonate-rock data; without additional carbonate-rock holes drilled in the area, information on the connection will remain limited. 
After convergence in the CP Basin-Frenchman Flat area, flow within the Yucca Flat tributary system begins diverging, either moving southward into the Ash Meadows flow system or southwestward into the Rock Valley tributary flow system (pl. 6). This divergence in flow is caused by an island of confining unit in the base of the upper plate of the Specter Range thrust (section A-A', fig. 6; pls. 4 and 6). Some groundwater flow may be channeled or diverted southwestward into the Rock Valley tributary flow system by southwest trending strike-slip and normal faults of the Rock Valley fault zone (pl. 6) as was proposed by McKee (1997). Alternatively, the influence of these faults may be minimal, allowing water to flow unobstructed into the Ash Meadows flow system. The head in the carbonate aquifer at well TW-F (3400 ft), located on the southern flanks of Skull Mountain in Rock Valley (pl. 4), is the sole point controlling the configuration of the contoured potentiometric surface and hydraulic gradients in the area. The hydraulic head of $2,387 \mathrm{ft}$ was adjusted downward by about $20 \mathrm{ft}$ to account for temperature effects (appendix 2; Winograd, 1970), and yet remains high relative to heads in carbonate wells to the south and east (pl. 4). This local potentiometric high centered about the TW-F area creates a southward gradient, seemingly forcing groundwater southward toward the Ash Meadows flow system (pl. 4). The precise location of the divide between the Rock Valley tributary flow system and Ash Meadows flow system is highly speculative, as is the relative amount of water portrayed moving into these two flow systems from the Yucca Flat tributary flow system (pl. 6). Any accurate prediction of the actual destination of a contaminant reaching the regional carbonate aquifer beneath Yucca Flat requires a more definitive understanding of these diverging flow paths. This understanding can be gained only by drilling additional wells into carbonate rock in the area at the downgradient end of the Yucca Flat tributary flow system.

\section{Rock Valley Tributary Flow System}

The Rock Valley tributary flow system is the only flow system delineated in the southeastern half of the study area that is not fully or partly tributary to the Ash Meadows flow system. The Rock Valley tributary flow system includes saturated carbonate rock beneath the area extending westward across Rock Valley into southern Jackass Flats and southern Crater Flat, and southward into south-central Amargosa Desert (pl. 6). The flow system conveys groundwater originating from within the study area in the upgradient Yucca Flat and Shoshone Mountain tributary flow systems to discharge areas outside the study area in southern Amargosa Desert (fig. 1). Specific discharge locations are not certain, but on the basis of interpreted flow directions (pls. 4 and 6) and the findings in previous investigations (Winograd and Thordarson, 1975; Waddell and others, 1984; and Laczniak and others, 1996), groundwater within the Rock Valley tributary flow system likely flows to smaller discharge areas with outflows of 1,000 acre-ft or less at Franklin Lake playa and the Franklin
Wells area (Laczniak and others, 2001, table 10), or even farther downgradient to discharge areas in Death Valley (fig. 1). The Rock Valley tributary flow system, as portrayed on plate 6, is bounded laterally on the north and south and vertically by confining unit (pls. 4 and 6 ). The tributary flow system consists of a block of regional carbonate aquifer isolated by confining unit from carbonate rock to the north by the north-directed CP thrust and from carbonate rock on the south by the south-directed Specter Range thrust (section A-A', fig. 6; pl. 4) .

Contours representing the potentiometric surface within the Rock Valley tributary flow system range from $2,380 \mathrm{ft}$ along its eastern boundary common with the Yucca Flat tributary flow system to 2,300 ft south of Amargosa Valley, Nevada, near the southwestern boundary of the study area. The potentiometric surface within the tributary flow system is constrained upgradient by the head at well TW-F (3400 ft) and downgradient by heads in a few wells outside the study area in southern Amargosa Desert (U.S. Geological Survey, National Water Information System, http://waterdata.usgs.gov/nwis).

Internally, contours are configured in accordance with the conceptualized geology and hydrology and honor the hydraulic heads at wells TW-5 and NC-EWD P-2D B (pl. 4). However, there is some question about the accuracy of the head at well N C-E WD P-2D B (pl. 4; appendix 2), which could alter the general flow conceptualization inferred from the contoured potentiometric surface. Well NC-EWPD-2DB, as originally drilled in 2000, was completed to be open only to carbonate rock (appendix 3), but because of problems associated with hole instability during drilling, there was concern about annular leakage from overlying saturated volcanic rocks (Levi Kryder, Nye County Nuclear Waste Repository Project Office, written commun., August 2008). In 2008, the hole was recompleted in an attempt to ensure isolation of, and deeper penetration into, carbonate rock. Because of continued hole instability issues experienced during recompletion, some concern remains about annular leakage and the influence of this leakage on the water level if assumed to represent solely groundwater conditions in the regional carbonate aquifer (Nye County Nuclear Waste Repository Project Office, 2009).

The mapped contours portray a relatively flat hydraulic gradient throughout most of the upgradient part of the flow system and a slight steepening of the gradient in the area of the Highway 95 fault (pl. 4). The steepening gradient reflects the presumed barrier-like nature of the buried Highway 95 fault (Sweetkind and others, 2004). The fault's damming effect is supported indirectly by evidence of paleosprings scattered about southern Crater Flat (Quade and others, 1995) and by the rather sharp decrease in the hydraulic head denoted by the relatively low head at well NC-EWD P-2D B. Alternatively, the steepening gradient required to fit contours to the low hydraulic head in well NC-EWD P-2D B could be placed more coincident with the northern extension of the Gravity fault where it crosses into Rock Valley (pl. 4). Although the Gravity fault is acknowledged as a flow barrier south of the study area 
and likely is responsible for forcing discharge at the springs in Ash Meadows, its hydraulic properties within the Rock Valley area are not fully understood nor documented by any local data (Winograd and Thordarson, 1975).

In addition to inflow through carbonate rock from the upgradient Yucca Flat tributary flow system, a minor amount of lateral inflow to the Rock Valley tributary flow system probably occurs from the Shoshone Mountain tributary flow system across the CP thrust along its northern boundary (section A-A', fig. 6; pls. 4 and 6) and from the west across bounding confining unit and deep carbonate-rock contacts. The direction of flow across the Specter Range thrust between the Rock Valley tributary and Ash Meadows flow systems is uncertain, in part, because of the speculative nature of the contours portrayed in this area (pl. 4). Any uncertainty in the actual flow direction cannot be resolved without additional wells providing hydraulic-head data in the carbonate aquifer on the north and south sides of the Specter Range thrust.

Another potential source of limited inflow into the carbonate aquifer of the Rock Valley tributary flow system is vertical leakage. Leakage may occur diffusely through confining unit, which generally overlies the aquifer, or across aquifer-on-aquifer contacts where the alluvial-volcanic aquifer directly overlies the carbonate aquifer (section B-B', pl. 2). Hydraulic gradients determined by differencing the contoured potentiometric surfaces in the alluvial-volcanic and regional carbonate aquifers indicate downward flow potential across the entire Rock Valley tributary flow system. The magnitude of the difference between the potentiometric surfaces decreases toward the downgradient end of the Rock Valley tributary flow system and nearly reaches zero. A slightly altered contour configuration that portrays heads only a few tens of feet higher in the downgradient end of the flow system would change the vertical flow direction from downward to upward. Considering the sparseness of the available data and the uncertainty associated with the lone head estimate in the area, a local upward gradient cannot be ruled out. To resolve uncertainties associated with the local vertical gradient, additional wells are needed that provide more spatial control on the hydraulic heads in both the regional carbonate and regional alluvialvolcanic aquifers south of Highway 95 (pl. 6).

\section{Belted Range and Sarcobatus Flat Tributary Flow Systems}

The two remaining tributary flow systems not yet discussed comprise the large disconnected sections of regional carbonate aquifer in the northern part of the study area. These two systems are the Belted Range tributary flow system in the northeast and the Sarcobatus Flat tributary flow system in the northwest. Both tributary flow systems include parts of the regional carbonate aquifer that are deficient in available head data; therefore, the inferred flow direction in these tributary flow systems is based solely on head data in overlying saturated Cenozoic rocks and in saturated rocks outside their mapped extent, and the general direction of the downgradient groundwater discharge areas.
The Belted Range tributary flow system includes that part of the shallow regional carbonate aquifer mapped in the far northeastern corner of the study area and is bounded by Quartzite Ridge and the Rhyolite Hills on the south and by Aqueduct Mesa and the Belted Range in the west (pl. 6). Within the study area, the flow system is bounded laterally by confining unit (section E-E', pl. 2). Some minor amount of lateral inflow of highland recharge through the bounding confining unit is likely. Another probable source of inflow is vertical leakage across confining unit where it overlies the tributary flow system throughout its western extent. Some additional recharge also may occur along the eastern flank of the Belted Range through unsaturated and partially saturated carbonate rock in areas where carbonate rock is exposed at land surface.

Outflow from the Belted Range tributary flow system is more speculative. Most of the outflow is portrayed as being eastward into the Groom Lake (ig. 1) part of Emigrant Valley (pls. 4 and 6). In the far northeastern part of the study area just north of Papoose Range (pl. 4), groundwater in the regional carbonate aquifer is assumed to be forced upward into the overlying alluvial-volcanic aquifer. This upward flow possibly occurs along the eastern margin of the tributary flow system as a result of the barrier-like nature of the fault bounding this margin, the low permeability of the adjacent playa deposits, the presence of a shallow confining unit along this margin, or some combination thereof. Once in the alluvial-volcanic aquifer, groundwater likely flows eastward across the fault into the Groom Lake area. Once in the Groom Lake area, some of the water is inferred to continue to flow southward, ultimately reaching the Ash Meadows flow system. Another area of potential outflow from the Belted Range tributary flow system would be into Penoyer Valley_ - a major discharge area located outside the study area north of Emigrant Valley (fig. 1). The designation of Penoyer Valley as a major discharge area (Harrill and others, 1988) would support the concept of inflow from Emigrant Valley to Penoyer Valley, but flow directions based on hydraulic gradients determined from available head data in the Penoyer Valley area (U.S. Geological Survey, National Water Information System, http://waterdata.usgs.gov/ nwis) indicate otherwise.

Some outflow from the Belted Range tributary flow system likely occurs across the south-bounding confining unit into the Yucca Flat tributary flow system, based on hydraulichead gradients defined by head data throughout the area (pl. 4; appendix 2). Any flow across this boundary is assumed to be minor because of the inferred continuity and low permeability of the intervening confining unit. This assumption of limited outflow is supported by the nearly 2,000-ft difference in hydraulic heads that is estimated between these two tributary flow systems. Uncertainty in the amount of inflow to Yucca Flat from the Belted Range tributary flow system is discussed earlier in section, "Yucca Flat Tributary Flow System." 
Considering that no underground nuclear tests were conducted in Emigrant Valley, the relevance of the Belted Range tributary flow system to radionuclide transport is only that of a source of potential inflow to the Yucca Flat tributary flow system - an area in which 659 underground nuclear tests were conducted prior to 1993 (U.S. Department of Energy, 2000b).

The Sarcobatus Flat tributary flow system occupies most of the northwestern corner of the study area. The tributary flow system is bounded on the east by the western extent of the Silent Canyon and Timber Mountain Caldera complexes and on the southwest by the Hogback fault (pl. 6). Flow directions, although speculative because of the absence of any supporting head data, are assumed to be westward toward discharge areas in Sarcobatus Flat and northern Death Valley (fig. 1; pls. 4 and 6). The primary source of inflow to the regional carbonate aquifer is across lateral and vertical contacts with the alluvialvolcanic aquifer. Minor inflow also occurs across lateral and vertical contacts with confining unit and possibly the deeper part of the carbonate aquifer (sections $\mathrm{A}-\mathrm{A}^{\prime}$ and $\mathrm{C}-\mathrm{C}^{\prime}$, pl. 2; pl. 4). Some minor amount of diffuse outflow toward the discharge area in Oasis Valley may occur along the southern boundary of the tributary flow system across the Colson Pond fault through the bounding confining unit.

Although no underground tests were conducted within the mapped extent of the Sarcobatus Flat tributary flow system, some testing was done near the far western boundary of the NTS (U.S. Department of Energy, 2000b). All these tests in the west were conducted in volcanic rock, east of the mapped boundary of the Sarcobatus Flat tributary flow system. As portrayed, any concern about the transport of testgenerated radionuclides into the regional carbonate aquifer of the Sarcobatus Flat tributary flow system is considered minor. This is because long travel distances through a complex sequence of permeable and less permeable volcanic and/ or carbonate rock would be required prior to ever reaching even the most upgradient part of the Sarcobatus Flat tributary flow system. The exact configuration of the flow system and the inferred interpretation of flow within the system are open to large uncertainties stemming from a lack of any "hard" carbonate-rock data in the area. The exact location of the mapped boundary of the tributary flow system and the depth and existence of carbonate rock throughout the area will remain uncertain until local data are acquired from which to develop an understanding of the deep subsurface. These uncertainties, even if resolved, would likely not increase concern about the potential for radionuclide transport through the Sarcobatus Flat tributary flow system.

\section{Limitations and Considerations}

The potentiometric surface and groundwater flow system maps of the Nevada Test Site and accompanying data sets in this report represent a synthesis of hydrologic and geologic data that have been collected and concepts of the flow systems that have been developed and published since the 1950s. The maps focus primarily on the regional groundwater flow paths most likely to transport radionuclides introduced by underground nuclear testing on the NTS. The report refines and integrates geologic and hydrologic concepts developed in previous studies to update the current understanding of groundwater flow. The results presented here serve as a basis for future work at the NTS, including investigations directed at environmental restoration, underground nuclear testing, and development of water supplies. This report may be especially useful as a source of hydraulic-head data, potentiometric surface configuration, and flow-system concepts for groundwater model development and calibration. In addition, the concepts developed in this report will provide a regional framework and flow-system perspective for local-scale hydrologic investigations.

The conceptualization of groundwater flow presented in this report is limited by geologic and hydrologic data deficiencies and simplifying assumptions regarding the geologic framework and hydrologic flow system. The geologic framework was simplified by grouping permeable rocks into two regional aquifers. This simplification portrays the flow systems as part of two distinct regional aquifers bounded and separated by confining units, when in reality the mix and diversity of geologic materials represents a continuum that ranges from highly transmissive to virtually impermeable deposits.

The analysis is focused primarily on the shallow flow system (less than 6,000 ft below land surface), in which nearly all data were collected. The deeper parts of the hydrologic system are assumed to be less active (flow rates are very low) and exert minimal influence on the transport of radionuclides and other test-generated contaminants off of the NTS. However, seismically active faults in actively extending areas may enhance permeability at depth. These fault-enhanced pathways could allow for some flow from the shallow to the deep parts of the flow system under a downward hydraulic gradient. Any potential for downward flow along seismically active faults into deep parts of the flow system was not addressed as part of this study.

Three-dimensional hydrostratigraphic framework models (HFM) are the geologic foundation used to delineate the extents of aquifers identified in this report. Although at least one HFM has been developed for each part of the study area, the various frameworks were constructed at different scales, often on the basis of different data sets. For example, the HFM for the Death Valley regional flow system (Faunt, Sweetkind, and Belcher, 2004) was constructed as a regional model that encompasses the entire NTS and a large region that surrounds it (fig. 1). As such, it is less detailed than local-scale HFMs constructed for the Pahute Mesa, Rainier Mesa-Shoshone Mountain, Yucca Flat-Climax Mine, and Frenchman Flat areas (Bechtel Nevada, 2002, 2005, 2006; National Security Technologies, LLC, 2007). The Death Valley regional HFM was used primarily to define aquifer extents in the southwestern part of the study area, where, with the exception 
of the Yucca Mountain area, drill-hole data are rather sparse. These differences in the scale of the framework models result in inconsistencies in subsurface geologic relations in areas where models overlap or abut each other. In addition, differences in the way that some hydrostratigraphic units were defined, in part related to real stratigraphic variability over the region, create some inconsistencies when hydrostratigraphic units are combined. Some geologic relations at great depth (such as the configuration of the carbonate system beneath Oasis Valley and Jackass Flats) are based on regional concepts derived from data obtained at widely separated surface outcrops. As such, uncertainty exists with regards to the presence and geometry of the pre-Cenozoic thrust beneath Yucca Mountain and Jackass Flats, and the interaction of detachment and caldera structures beneath Oasis Valley. Much uncertainty also exists regarding the presence and extent of carbonate aquifer in the northeastern and northwestern parts of the study area.

In developing the flow conceptualization presented in this study, many assumptions were made as to the significance of the various structures controlling groundwater flow. In some cases, the preponderance of data support the interpretation that a structure controls flow; in other cases, the interpretation is based only on assumptions about the extent, permeability, or ability of the structure to juxtapose geologic units.

Examples of structures assumed to act as flow barriers, but for which few data are available to support the assumption, include the Highway 95 fault (for the carbonate aquifer), the northern end of the Gravity fault, the Specter Range thrust, the CP thrust, and the Carpetbag-Topgallant fault. Although some faults in the study area are identified as potentially transmissive corridors within the carbonate-rock aquifers, there have been few attempts to identify specific active faults, determine their flow properties, or define their relationship to the potentiometric surface. Recognition of these structures as transmissive corridors is based mostly on regional structural studies (Faunt, 1997; Potter, Sweetkind and others, 2002) rather than on any detailed analysis of specific faults or fault zones.

Potentiometric contours and flow arrows shown on the plates are intended to portray general directions of regional groundwater flow. The effects of anisotropy on regional flow directions were accounted for indirectly in this analysis. At the local scale, however, anisotropy can cause flow to take tortuous paths that may differ from the regional flow direction. At a more regional scale, faults and fracture zones form flow barriers or preferred pathways, creating large-scale anisotropy that also can result in flow paths that deviate from the directions implied by the potentiometric contours. As portrayed, head contours only partially account for vertical hydraulic gradients. The assumption was made that within a mapped aquifer system, vertical gradients were negligible relative to horizontal gradients. In most areas, this assumption likely is valid. However, in recharge areas, such as on Pahute
Mesa, vertical gradients can be large and could introduce a substantial amount of vertical flow into the flow system.

Thermally driven convection, potentially introduced by deep-seated, local heat sources beneath the NTS, could affect groundwater flow (Fridrich and others, 1998). As determined from the contour configurations presented in this report, however, flow directions disregard thermal convection as a significant factor affecting flow in the shallow groundwater system. Furthermore, an analysis of convection-driven flow is beyond the scope of this report and would require the development of numerical models coupling groundwater and heat flow. More importantly, the thermal information and temperature data required by these coupled models does not exist.

Other limitations to the flow conceptualization include a lack of hydraulic-head data in some parts of the study area and potential shortcomings associated with the assumptions used to convert measured water levels into equivalent hydraulic heads. For the alluvial-volcanic aquifer, hydraulichead data were sparse in the areas surrounding Timber and Black Mountains and immediately north of Yucca Mountain. For the carbonate aquifer, head data were sparse throughout most of the study area, with the exception of Yucca Flat. Lack of head data created particular problems in areas where hydraulic continuity between parts of aquifers was believed to be impeded or nonexistent. In these areas, prediction of the head in a potentially isolated aquifer was difficult because the degree of isolation of the aquifer was unknown and, therefore, nearby head data could not necessarily be used to predict the head. Where water-level measurements were available, their conversion to a predevelopment hydraulic head representing a specific aquifer was based on several assumptions including: (1) the well is open only to the hydrologic unit that was targeted by the completion; (2) the water level represents natural conditions in the targeted hydrologic unit; (3) temporally measured water levels can all be used to represent predevelopment conditions; and (4) the only correction required to convert water-level altitude to hydraulic head is for density effects caused by differences in the temperature of the well bore water column between wells.

Flow systems and their tributary flow systems are used only to convey general directions of groundwater flow. Boundaries for these systems are approximate at best. These boundaries were defined primarily on the basis of aquiferconfining unit contacts, hydraulic-head data, structural controls, and interpreted flow lines that separate unique flow paths. The boundaries were drawn with the intent of delineating areas of unique groundwater chemistry. Although geochemical evidence was considered in the development of these flow systems, no formal attempt was made to integrate water-chemistry data into this analysis. However, it is recognized that the flow system and tributary flow system boundaries shown on plates 5 and 6 could potentially be located more accurately using a rigorous geochemical analysis. 


\section{Summary}

Accurate prediction of transport of radionuclides and other test-generated contaminants beneath the Nevada Test Site area requires an understanding of the rate and direction of groundwater flow within the major aquifers of the area. The spatial distribution of hydraulic heads across this area, a major control on the direction and rate of transport, has been portrayed historically by maps showing a single potentiometric surface. These maps, by their very nature, ignore vertical flow components and depict the complex subsurface geology as a single, continuous, regionally extensive flow system. In actuality, the groundwater flow system is made up of multiple aquifers that are separated hydraulically by confining units. The hydraulic separation creates multiple, semi-independent flow systems in which flow is controlled, in part, by the hydraulic-head gradient within each aquifer.

The approach used to conceptualize groundwater flow was to construct potentiometric surface maps of the major aquifers forming distinct flow systems in the study area. Aquifers were identified and mapped by using a composite hydrostratigraphic framework model derived by merging previously published three-dimensional hydrostratigraphic framework models for the Pahute Mesa, Rainier MesaShoshone Mountain, Yucca Flat-Climax Mine, Frenchman Flat, and Death Valley regional flow system areas. Framework units with similar hydraulic properties and rock type were grouped together into seven subsurface hydrologic unit types: the alluvial aquifer, alluvial confining unit, volcanic aquifer, volcanic confining unit, volcanic composite unit, carbonate aquifer, and siliceous confining unit. Permeable subsurface hydrologic unit types were grouped into two aquifer types (alluvial-volcanic and carbonate) and mapped as either regional or local aquifers. Thick, contiguous blocks of aquifer are considered regional if they are hydraulically connected to adjacent aquifers and together form part of a large flow system. Local aquifers are stratigraphically or structurally isolated, hydraulically restricted, and generally drain only to adjacent confining units.

Mean values of predevelopment hydraulic heads were calculated for 800 wells that were used to map potentiometric contours in the study area. Heads associated with alluvialvolcanic and carbonate aquifer types were plotted and contoured to represent predevelopment conditions in the shallow part (within about 6,000 ft of land surface) of the major aquifers. Contouring took into consideration hydraulic gradients, likely recharge areas, discharge areas, and lateral and vertical continuity of flow systems. Maps included in the report show the spatial distribution, dominant flow directions, and areas of lateral inflows to and outflows from each of the aquifers.

The extents of regional alluvial-volcanic and carbonate aquifers and their contoured surfaces were used to delineate flow systems and tributary flow systems. A tributary flow system delineates an area of regional aquifer having recharge areas and flow paths that may contribute water of a unique geochemistry to a downgradient flow system. A flow system is sustained by water from tributary flow systems and may form part of a larger regional flow system. Delineated flow systems (and their tributary components) generally describe the most likely groundwater flow path or paths away from underground nuclear test areas.

The alluvial-volcanic aquifer includes Pliocene and younger, generally unconsolidated alluvium and Miocene volcanic rocks. Deposits forming alluvial aquifer, although thin and of limited extent, are most prevalent in the eastern half of the NTS and in the valleys southeast and southwest of the NTS. Volcanic rocks and their associated caldera-collapse structures dominate the northwestern and west-central parts of the NTS. Fractured volcanic rocks within and adjacent to the calderas at the NTS are sufficiently extensive and locally thick enough to be an important regional aquifer.

Most of the water in the regional alluvial-volcanic aquifer within the study area flows to two groundwater flow systems: Oasis Valley and Alkali Flat-Furnace Creek Ranch (fig. 7). These flow systems, which cover the western half of the study area, underlie Pahute Mesa to the north and extend southward into the Amargosa Desert. Most of the alluvialvolcanic aquifers in the eastern half of the study area are local and isolated from regional flow. Important local alluvialvolcanic aquifers, from an underground testing perspective, are present under Yucca and Frenchman Flats.

The Black Mountain and Pahute Mesa tributary flow systems, in the northwestern quarter of the study area, contribute water to the Oasis Valley flow system (fig. 7). Flow in the Oasis Valley flow system and its tributaries is generally south-southwesterly towards the Oasis valley discharge area. Hydraulic heads are interpreted to range from about 5,000 ft in the recharge area beneath Pahute Mesa, Rainier Mesa, and the Belted Range to about 3,300 ft in the downgradient end of Oasis Valley. The presence of elevated heads in wells is common in the recharge area, where aquifers are stacked vertically and separated by extensive confining units. The bulk of the water in the study area flowing beneath Pahute Mesa is interpreted to pass through Oasis Valley. The implication of this conceptualization for radionuclide transport is that any water flowing beneath the historical testing area in Pahute Mesa ultimately will pass through Oasis Valley rather than moving southward toward the Yucca Mountain area and into the Crater Flat or Fortymile Wash tributary flow systems.

The Upper Amargosa Desert, Crater Flat, and Fortymile Wash tributary flow systems, in the southwestern quarter of the study area, contribute water to the Alkali Flat-Furnace Creek Ranch flow system (fig. 7). Flow in the alluvial-volcanic part of the Alkali Flat-Furnace Creek Ranch flow system and its tributaries originates as recharge from highlands near Rainier Mesa and from Timber Mountain, Shoshone Mountain, and other smaller highland areas north of Yucca Mountain. Groundwater flows in a generally southerly direction out of the study area towards probable outside discharge areas in Franklin Wells area and Franklin Lake playa. Flow paths are 


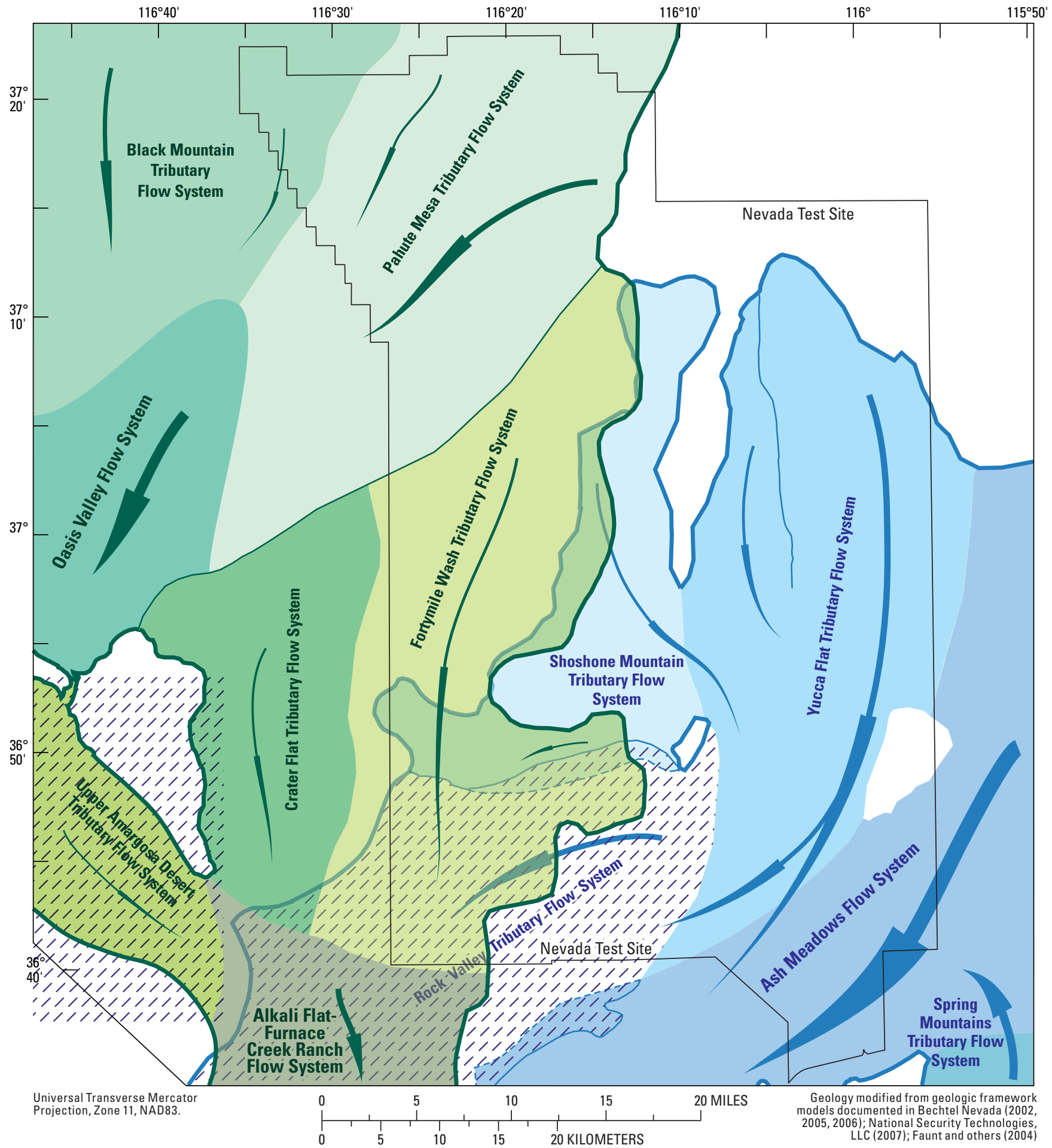

EXPLANATION

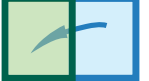

R egional groundwater flow systems - Green and blue colors denote alluvial-volcanic and carbonate flow systems, respectively. Arrow indicates regional flow direction. Arrow width indicates relative flow volume. Carbonate flow system boundary dashed where aquifer extends beneath extent of another carbonate flow system. Belted Range and Sarcobatus Flat tributary flow systems not shown

Figure 7. Major groundwater flow systems of the regional alluvial-volcanic and carbonate aquifers in the Nevada Test Site area, Nevada. 
disrupted by various high-gradient areas beneath northern Yucca Mountain, western Yucca Mountain, and southern Crater Flat. These high-gradient areas, which likely limit flow across them, are associated with structural features, including the Solitario Canyon and Highway 95 faults and the Claim Canyon caldera. Flow boundaries between water moving southward into the Amargosa Desert and water moving southwestward into Oasis Valley are poorly constrained in the area of Timber Mountain because of limited data.

The carbonate aquifer, consisting primarily of Paleozoic carbonate rock, is mapped as a nearly continuous unit across the southeastern half of the study area. The extent and subsurface configuration of the carbonate aquifer in the study area is constrained by pre-Cenozoic thrust faults and by the occurrence of calderas, large-magnitude normal-offset faults, and anticlinal upwarp. Pre-Cenozoic thrusts and Cenozoic normal faults and strike-slip faults have disrupted the aquifer, and in places have created isolated, fault-bounded blocks of overlapping regional and local carbonate aquifer. The local occurrence of confining unit at the base of regional thrust sheets creates internal divides in the regional carbonate aquifer that can divert groundwater flow. In the southern part of the NTS area, the north-directed CP thrust and the south-directed Specter Range and Belted Range thrusts act as structural barriers and internally subdivide the regional carbonate aquifer by redirecting and constricting regional groundwater flow.

Heads in the carbonate aquifers generally decrease southward across the study area. The highest carbonate heads in the study area are mostly in the carbonate-rock blocks mapped as local aquifers. Typical heads in these local carbonate aquifers are elevated by more than $500 \mathrm{ft}$ from heads in the more extensive regional carbonate aquifer mapped throughout the southeastern half of the study area. Hydraulic-head data in the regional carbonate aquifer vary by less than $200 \mathrm{ft}$. Horizontal hydraulic gradients in this aquifer are low, seldom exceeding $5 \mathrm{ft} / \mathrm{mi}$ and more typically less than $1 \mathrm{ft} / \mathrm{mi}$. Groundwater flow in the regional carbonate aquifer generally is toward discharge areas south and west of the study area. Destinations for this outflow are one of five general areas: Ash Meadows, Franklin Lake playa, Franklin Wells, central Death Valley, or Sarcobatus Flat. Vertical gradients between contoured potentiometric surfaces in the carbonate and the alluvial-volcanic aquifers generally indicate vertical leakage to the carbonate aquifer, across saturated, usually less permeable rocks that overlie the regional carbonate aquifer. Only in two areas is vertical flow inferred to be upward out of the regional carbonate aquifer: in the northern part of Yucca Mountain and in eastern Emigrant Valley. Based on the flow conceptualization, one flow system and six tributary flow systems were delineated within the study area: the Ash Meadows flow system and the Shoshone Mountain, Yucca Flat, Rock Valley, and Spring Mountains tributary flow systems in the southeastern half of the study area (fig. 7); and the Belted Range and Sarcobatus Flat tributary flow systems in the northeastern and northwestern parts of the study area, respectively.
The Ash Meadows flow system includes regional carbonate aquifer mapped in the southeastern part of the study area and is presumed to extend outward from the study area's eastern and southern boundaries (fig. 7). The largest component of inflow enters the system from the east through an adjacent part of the regional carbonate aquifer that extends outward across the eastern boundary of the study area. The other large inflow component is contributed by the Spring Mountains tributary flow system through a block of carbonate rock that extends south and southeast into the nearby Spring Mountains. A small amount of groundwater flows into the Ash Meadows flow system internally from within the study area through regional carbonate aquifer that makes up the Shoshone Mountain and Yucca Flat tributary flow systems.

The Shoshone Mountain tributary flow system is centered at about the middle of the study area (fig. 7) and includes the block of regional carbonate aquifer underlying Shoshone Mountain and the Eleana Range. The flow system extends eastward into Mid Valley and westward to include carbonate rock beneath east-central Yucca Mountain. The tributary flow system is terminated on the south by confining unit in the base of the upper plate of the CP thrust. Groundwater entering the Shoshone Mountain tributary flow system from the north generally flows southward until discharging into the Yucca Flat tributary flow system through an eastward extension of the regional carbonate aquifer in the area of Mid Valley. Water in the Shoshone Mountain tributary flow system is forced southward by the presence of a thick section of confining unit underlying Syncline Ridge, which divides the shallow part of the regional carbonate aquifer into two north-south trending pieces of regional carbonate aquifer - the western piece is part of the Shoshone Mountain tributary flow system, and the eastern piece is part of the Yucca Flat tributary flow system.

The Yucca Flat tributary flow system, which lies entirely within the study area, extends southward through Yucca Flat and CP Basin, and into the northwestern part of Frenchman Flat (fig. 7). The Yucca Flat tributary flow system itself is made up of three branches generally delineated on the basis of internal geologic structures. This multi-branch flow system consists of a main branch in Yucca Flat, which makes up the eastern two thirds of the tributary flow system, and two western branches, which feed the main branch. The two western branches are separated from the main branch by structural features associated with the CP thrust and the Carpetbag-Topgallant fault. The upgradient part of the main branch has a regional southern component of flow superimposed locally by inward flow toward the branch's central axis. Groundwater flow within this branch is of particular importance because most of the 671 underground nuclear tests in Yucca Flat and Frenchman Flat were conducted within its boundaries. Groundwater generally flows southward through each of the three branches of the Yucca Flat tributary flow system and converges with water flowing eastward from the Shoshone Mountain tributary flow system. From this convergence, water flows southward a short distance 
before diverging and flowing either southwestward into the Rock Valley tributary flow system or southward into the Ash Meadows flow system. This inferred divergence in flow is caused by an island of confining unit in the base of the upper plate of the Specter Range thrust.

The Rock Valley tributary flow system is the only carbonate flow system delineated in the southeastern half of the study area that is not fully or partly tributary to the Ash Meadows flow system. This tributary flow system includes saturated carbonate rock beneath the area extending westward across Rock Valley into southern Jackass Flats and southern Crater Flat, and southward into south-central Amargosa Desert (fig. 7). The flow system conveys groundwater originating from within the study area in the upgradient Yucca Flat and Shoshone Mountain tributary flow systems to discharge areas outside the study area in southern Amargosa Desert. The tributary flow system consists of a block of regional carbonate aquifer isolated by confining unit from carbonate rock to the north by the north-directed CP thrust and from carbonate rock on the south by the south-directed Specter Range thrust. The mapped contours portray a relatively flat hydraulic gradient throughout the upgradient part of the flow system and a slight steepening of the gradient in the area of the Highway 95 fault, which is assumed to impede groundwater flow.

\section{References Cited}

Barton, C.A., Zoback, M.D., and Moos, D., 1995, Fluid flow along potentially active faults in crystalline rock: Geology, v. 23, p. 683-686.

Bechtel Nevada, 2002, A hydrostratigraphic model and alternatives for the groundwater flow and contaminant transport model of Corrective Action Units 101 and 102Central and western Pahute Mesa, Nye County, Nevada: U.S. Department of Energy Report DOE/NV /11718-706, 383 p.

Bechtel Nevada, 2005, A hydrostratigraphic framework model and alternatives for the groundwater flow and contaminant transport model of corrective action unit 98: Frenchman Flat, Clark, Lincoln and Nye Counties, Nevada: U.S. Department of Energy DOE/NV/11718-1064, 240 p.

Bechtel Nevada, 2006, A hydrostratigraphic model and alternatives for the groundwater flow and contaminant transport model of Corrective Action Unit 97-Yucca FlatClimax Mine, Lincoln and Nye Counties, Nevada: U.S. Department of Energy Report DOE/NV/11718-1119, 288 p.
Bechtel SAIC Company, LLC, 2004, Water-level data analysis for the saturated zone site-scale flow and transport model: Bechtel SAIC Company, LLC Report ANLNBS-HS-000034 REV 02, revised 2005, 150 p.

Belcher, W.R., ed., 2004, Death Valley regional groundwater flow system, Nevada and California-Hydrogeologic framework and transient ground-water flow model: U.S. Geological Survey Scientific Investigations Report 2004-5205, 408 p.

Belcher, W.R., Elliott, P.E., and Geldon, A.L., 2001, Hydraulic-property estimates for use with a transient ground-water flow model of the Death Valley regional ground-water flow system, Nevada and California: U.S. Geological Survey Water-Resources Investigations Report 01-4120, 28 p.

Best, M.G., Christiansen, E.H., Deino, A.L., Gromme, C.S., McKee, E.H., and Noble, D.C., 1989, Excursion 3AEocene through Miocene volcanism in the Great Basin of the Western United States, in Chapin, C.E., and Zidek, J., eds., Field excursions to volcanic terranes in the Western United States, v. II, Cascades and Intermountain West: New Mexico Bureau of Mines and Mineral Resources Memoir 47, p. 91-133.

Blankennagel, R.K., and Weir, J.E., Jr., 1973, Geohydrology of the eastern part of Pahute Mesa, Nevada Test Site, Nye County, Nevada: U.S. Geological Survey Professional Paper 712-B, 35 p.

Brocher, T.M., Carr, M.D., Fox, K.F., and Hart, P.E., 1993, Seismic reflection profiling across Tertiary extensional structures in the eastern Amargosa Desert, southern Nevada, Basin and Range province: Geological Society of America Bulletin, v. 105, p. 30-46.

Byers, F.M., Jr., Carr, W.J., Christiansen, R.L., Lipman, P.W., Orkild, P.P., and Quinlivan, W.D., 1976, Geologic map of the Timber Mountain caldera area, Nye County, Nevada: U.S. Geological Survey Miscellaneous Investigations Series Map I-891, scale 1:48,000, 10 p.

Byers, F.M., Jr., Carr, W.J., Orkild, P.P., Quinlivan, W.D., and Sargent, K.A., 1976, Volcanic suites and related cauldrons of the Timber Mountain-Oasis Valley caldera complex, southern Nevada: U.S. Geological Survey Professional Paper 919, 70 p.

Carle, S.F., Zavarin, Mavrik, Sun, Yunwei, and Pawloski, G.A., 2008, Evaluation of hydrologic source term processes for underground nuclear tests in Yucca Flat, Nevada Test Site - carbonate tests: Lawrence Livermore National Laboratory Report LLNL-TR-403485, 372 p. 
Carr, W.J., 1984, Regional structural setting of Yucca Mountain, southeastern Nevada, and late Cenozoic rates of tectonic activity in part of the southwestern Great Basin, Nevada and California: U.S. Geological Survey Open-File Report 84-854, 98 p.

Carr, W.J., Grow, J.A., and Keller, S.M., 1995, Lithologic and geophysical logs of drill holes Felderhoff Federal 5-1 and 25-1, Amargosa Desert, Nye County, Nevada: U.S. Geological Survey Open-File Report 95-155, 14 p.

Carr, M.D., Waddell, S.J., Vick, G.S., Stock, J.M., Monsen, S.A., Harris, A.G., Cork, B.W., and Byers, F.M., Jr., 1986, Geology of drill hole UE-25p\#1-A test hole into preTertiary rocks near Yucca Mountain, southern Nevada: U.S. Geological Survey Open-File Report 86-175, 87 p.

Caskey, S.J., and Schweickert, R.A., 1992, Mesozoic deformation in the Nevada Test Site and vicinity: Framework of the Cordilleran fold and thrust belt and Tertiary extension north of Las Vegas Valley: Tectonics, v. 11, p. 1314-1331.

Claassen, H.C., 1985, Sources and mechanisms of recharge for ground water in the west-central Amargosa Desert, Nevada; A geochemical interpretation: U.S. Geological Survey Professional Paper 712-F, $30 \mathrm{p}$.

Cole, J.C., 1997, Major structural controls on the distribution of pre-Tertiary rocks, Nevada Test Site vicinity, southern Nevada: U.S. Geological Survey Open-File Report 97-533, $19 \mathrm{p}$.

Cole, J.C., and Cashman, P.H., 1999, Structural relationships of pre-Tertiary rocks in the Nevada Test Site region, southern Nevada: U.S. Geological Survey Professional Paper 1607, $39 \mathrm{p}$.

Craig, R.W., and Robison, J. H., 1984, Geohydrology of rocks penetrated by test well UE-25p\#1, Yucca Mountain area, Nye County, Nevada: U.S. Geological Survey WaterResources Investigations Report 84-4248, 57 p.

Czarnecki, J.B., 1989, Characterization of the subregional ground-water flow system at Yucca Mountain and vicinity, Nevada-California: Radioactive Waste Management and Nuclear Fuel Cycle, v. 13, p. 51-61.

D’Agnese, F.A., Faunt, C.C., Turner, A.K., and Hill, M.C., 1997, Hydrogeologic evaluation and numerical simulation of the Death Valley regional ground-water flow system, Nevada and California: U.S. Geological Survey WaterResources Investigations Report 96-4300, 124 p.
D’Agnese, F.A., Faunt, C.C., and Turner, A.K., 1998, An estimated potentiometric surface of the Death Valley region, Nevada and California, developed using Geographic Information System and automated interpolation techniques: U.S. Geological Survey Water-Resources Investigations Report 97-4052, xx p.

Day, W.C., Dickerson, R.P., Potter, C.J., Sweetkind, D.S., San Juan, C.A., Drake, R.M. II, and Fridrich, C.J., 1998, Bedrock geologic map of the Yucca Mountain area, Nye County, Nevada: U.S. Geological Survey Geologic Investigations Series Map I-2627, scale 1:24,000, 21-p. text.

DeNovio, Nicole, Ruskauff, Greg, Aly, Alaa, Pickens, John, Ewing, John, Fryer, William, Jones, Toya, Farnham, Irene, Kwicklis, Edward, and Gable, Carl, 2006, Phase II groundwater flow model of Corrective Action Unit 98: Frenchman Flat, Nevada Test Site, Nye County, Nevada: Stoller-Navarro Joint Venture Report S-N/99205-074, $655 \mathrm{p}$.

Dettinger, M.D., Harrill, J.R., Schmidt, D.L., and Hess, J.W., 1995, Distribution of carbonate-rock aquifers and the potential for their development, southern Nevada and parts of Arizona, California, and Utah: U.S. Geological Survey Water-Resources Investigations Report 91-4146, 100 p.

Dockery, Holly, 1984, Rotation of late Cenozoic extensional stresses, Yucca Flat region, Nevada Test Site, Nevada: Houston, Texas, Rice University, Ph.D. thesis, 77 p., 10 plates.

Doty, G.C., and Thordarson, William, 1983, Water table in rocks of Cenozoic and Paleozoic age, 1980, Yucca Flat, Nevada Test Site, Nevada: U.S. Geological Survey Water-Resources Investigation Report 83-4067, 1 pl.

Ervin, E.M., Luckey, R.R., and Burkhardt, D.J., 1994, Revised potentiometric-surface map, Yucca Mountain and vicinity, Nevada: U.S. Geological Survey Water-Resources Investigation Report 93-4000, 17 p., 1 pl.

Faunt, C.C., 1997, Effect of faulting on ground-water movement in the Death Valley region, Nevada and California: U.S. Geological Survey Water-Resources Investigations Report 95-4132, 42 p., 1 plate.

Faunt, C.C., Blainey, J.B., Hill, M.C., D’Agnese, F.A., and O’Brien, G.M., 2004, Transient numerical model, in Belcher, W.R., ed., Chapter F of Death Valley regional ground-water flow system, Nevada and CaliforniaHydrogeologic framework and transient ground-water flow model: U.S. Geological Survey Scientific Investigations Report 2004-5205, p. 257-352. 
Faunt, C.C., D’Agnese, F.A., and O’Brien, G.M., 2004, Hydrology, in Belcher, W.R., ed., Chapter D of Death Valley regional ground-water flow system, Nevada and California-Hydrogeologic framework and transient ground-water flow model: U.S. Geological Survey Scientific Investigations Report 2004-5205, p. 138-164.

Faunt, C.C., Sweetkind, D.S., and Belcher, W.R., 2004, Three-dimensional hydrogeologic framework model, in Belcher, W.R., ed., Chapter E of Death Valley regional ground-water flow system, Nevada and CaliforniaHydrogeologic framework and transient ground-water flow model: U.S. Geological Survey Scientific Investigations Report-2004-5205, p. 165-256.

Fenelon, J.M., 2000, Quality assurance and analysis of water levels in wells on Pahute Mesa and vicinity, Nevada Test Site, Nye County, Nevada: U.S. Geological Survey Water-Resources Investigations Report 00-4014, 29 p.

Fenelon, J.M., 2005, Analysis of ground-water levels and associated trends in Yucca Flat, Nevada Test Site, Nye County, Nevada, 1951-2003: U.S. Geological Survey Scientific Investigations Report 2005-5175, 87 p., at URL: http://pubs.water.usgs.gov/sir2005-5175.

Fenelon, J.M., 2006, Database of ground-water levels in the vicinity of Rainier Mesa, Nevada Test Site, Nye County, Nevada, 1957-2005: U.S. Geological Survey Data Series 190, version 1.10, October 2007, 14 p.

Fenelon, J.M., Laczniak, R.J., and Halford, K.J., 2008, Predevelopment water-level contours for aquifers in the Rainier Mesa and Shoshone Mountain area of the Nevada Test Site, Nye County, Nevada: U.S. Geological Survey Scientific Investigations Report 2008-5044, 38 p.

Fenelon, J.M., and Moreo, M.T., 2002, Trend analysis of ground-water levels and spring discharge in the Yucca Mountain region, Nevada and California, 1960-2003: U.S. Geological Survey Water-Resources Investigations Report 02-4178, 97 p.

Fenske, P.R., and Carnahan, C.L., 1975, Water table and related maps for Nevada Test Site and Central Nevada Test Area: U.S. Energy Research and Development Administration, Nevada Operations Office Report NVO-1253-9, 18 p.

Ferguson, J.F., Cogbill, A.H., and Warren, R.G., 1994, A geophysical-geological transect of the Silent Canyon caldera complex, Pahute Mesa, Nevada: Journal of Geophysical Research, v. 99, p. 4323-4339.
Ferrill, D.A., Stamatakos, J.A., and Sims, D., 1999, Normal fault corrugation - Implications for growth and seismicity of active normal faults: Journal of Structural Geology, v. 21, p. $1027-1038$.

Freeze, R.A., and Witherspoon, P.A., 1967, Theoretical analysis of regional groundwater flow -2 . Effect of watertable configuration and subsurface permeability variation: Water Resources Research, v. 3, no. 2, p. 623-634.

Fridrich, C.J., Dudley, W.W., Jr., and Stuckless, J.S., 1994, Hydrogeologic analysis of the saturated-zone groundwater system under Yucca Mountain, Nevada: Journal of Hydrology, v. 154, p. 133-168.

Fridrich, C.J., Ge, S., and Sass, J., 1998, On the mechanism of the large hydraulic gradient under Yucca Mountain, Nevada: U.S. Geological Survey Open-File Report 98-119, 25 p.

Fridrich, C.J., Minor, S.A., Slate, J.L., and Ryder, P.L., 2007, Geologic map of Oasis Valley spring-discharge area and vicinity, Nye County, Nevada: U.S. Geological Survey Scientific Investigations Map 2957, 25 p., scale 1:50,000.

Gibbons, A.B., Hinrichs, E.N., Hansen, W.R., and Lemke, R.W., 1963, Geology of the Rainier Mesa quadrangle, Nye County, Nevada: U.S. Geological Survey Geologic Quadrangle Map GQ-215, scale 1:24,000.

Gillespie, David, 2005, Temperature profiles and hydrologic implications from the Nevada Test Site area: Desert Research Institute Publication No. 45211, Department of Energy DOE/NV/13609-40, 102 p.

Grauch, V.J., Sawyer, D.A., Fridrich, C.J., and Hudson, M.R., 1999, Geophysical framework of the southwestern Nevada volcanic field and hydrogeologic implications: U.S. Geological Survey Professional Paper 1608, 39 p.

Hale, G.S., Trudeau, D.T., and Savard, C.S., 1995, Waterlevel data from wells and test holes through 1991 and potentiometric contours as of 1991 for Yucca Flat, Nevada Test Site, Nye County, Nevada: U.S. Geological Survey Water-Resources Investigation Report 95-4177, 1 pl.

Harrill, J.R., and Bedinger, M.S., 2004, Estimated model boundary flows, in Belcher, W.R., ed., Appendix 2 of Death Valley regional ground-water flow system, Nevada and California-Hydrogeologic framework and transient ground-water flow model: U.S. Geological Survey Scientific Investigations Report 2004-5205, p. 375-408. 
Harrill, J.R., Gates, J.S., and Thomas, J.M., 1988, Major ground-water flow systems in the Great Basin region of Nevada, Utah, and adjacent States: U.S. Geological Survey Hydrologic Investigations Atlas HA-694-C, scale $1: 1,000,000$.

Harrill, J.R., and Prudic, D.E., 1998, Aquifer systems in the Great Basin region of Nevada, Utah, and adjacent States-A summary report: U.S. Geological Survey Professional Paper 1409-A, 66 p.

Hevesi, J.A., Flint, A.L., and Flint, L.E., 2003, Simulation of net infiltration and potential recharge using a distributedparameter watershed model of the Death Valley region, Nevada and California: U.S. Geological Survey Water-Resources Investigations Report 03-4090, 161 p.

Hildenbrand, T.G., Phelps, G.A., and Mankinen, E.A., 2006, Inversion of gravity data to define the pre-Cenozoic surface and regional structures possibly influencing groundwater flow in the Rainier Mesa region, Nye County, Nevada: U.S. Geological Survey Open-File Report 2006-1299, 28 p.

Johnson, R.B., and Ege, J.R., 1964, Geology of the Pluto Site, Area 401, Nevada Test Site, Nye County, Nevada: U.S. Geological Survey Open-File Report 64-91, 127 p.

Laczniak, R.J., Cole, J.C., Sawyer, D.A., and Trudeau, D.A., 1996, Summary of hydrogeologic controls on groundwater flow at the Nevada Test Site, Nye County, Nevada: U.S. Geological Survey Water-Resources Investigations Report 96-4109, 59 p.

Laczniak, R.J., Smith, J.L., Elliott, P.E., DeMeo, G.A., Chatigny, M.A., and Roemer, G.J., 2001, Ground-water discharge determined from estimates of evapotranspiration, Death Valley regional flow system, Nevada and California: U.S. Geological Survey Water-Resources Investigations Report 01-4195, 51 p.

Lipman, P.W., 1984, The roots of ash flow calderas in western North America - Windows into the tops of granitic batholiths: Journal of Geophysical Research, v. 89, p. 8801-8841.

Ludington, S., Cox, D.P., Moring, B.C., and Leonard, K.W., 1996, Cenozoic volcanic geology of Nevada: Nevada Bureau of Mines and Geology Open-File Report 96-2, chapter 5, p. 5-1-5-10.

Mankinen, E.A., Hildenbrand, T.G., Fridrich, C.J., McKee, E.H., and Schenkel, C.J., 2003, Geophysical setting of the Pahute Mesa-Oasis Valley region, southern Nevada: Nevada Bureau of Mines and Geology, Report 50, CD-ROM, 45 p.
McCutcheon, S.C., Martin, J.L., and Barnwell, Jr., T.O., 1993, Water quality, in Maidment, D.R., ed., Handbook of Hydrology: New York, McGraw-Hill, Inc., p. 11.2-11.6.

McKee, E.H., 1997, Evaluation of geologic structure guiding ground water flow south and west of Frenchman Flat, Nevada Test Site: U.S. Geological Survey Open-File Report 97-734, 26 p.

McKee, E.H., Wickham, T.A., and Wheeler, K.L., 1998, Evaluation of faults and their effect on ground-water flow southwest of Frenchman Flat, Nye and Clark Counties, Nevada-A digital database: U.S. Geological Survey Open-File Report 98-580, 16 p., 4 plates.

Meinzer, O.E., 1923, Outline of ground-water hydrology, with definitions: U.S. Geological Survey Water-Supply Paper 494, $71 \mathrm{p}$.

Monsen, S.A., Carr, M.D., Reheis, M.C., and Orkild, P.P., 1992, Geologic map of Bare Mountain, Nye County, Nevada: U.S. Geological Survey Miscellaneous Investigations Series Map I- 2201, scale 1:24,000, 6-p. text.

Moreo, M.T., and Justet, Leigh, 2008, Update to the groundwater withdrawals database for the Death Valley regional ground-water flow system, Nevada and California, 19132003: U.S. Geological Survey Data Series 340, 10 p.

National Security Technologies, LLC, 2007, A hydrostratigraphic model and alternatives for the groundwater flow and contaminant transport model of Corrective Action Unit 99-Rainier Mesa-Shoshone Mountain, Nye County, Nevada: U.S. Department of Energy Report DOE/NV/25946—146, 302 p.

Nye County Nuclear Waste Repository Project, 2009, NC-EWDP-2DB well completion diagram (meta data): Nye County Nuclear Waste Repository Project Office RID No. 7559.00, accessed October 2009 at URL: http://www. nyecounty.com/ewdpmain.htm.

O’Hagan, M.D., and Laczniak, R.L., 1996, Ground-water levels beneath eastern Pahute Mesa and vicinity, Nevada Test Site, Nye County, Nevada: U.S. Geological Survey Water-Resources Investigations Report 96-4042, 1 sheet.

Poole, F.G., and Sandberg, C.A., 1977, Mississippian paleogeography and tectonics of the western United States, in Stewart, J.H., Stevens, C.H., and Fritsche, A.E., eds., Paleozoic paleogeography of the western United States, Pacific Coast Paleogeography Symposium 1: Society of Economic Paleontologists and Mineralogists, p. 67-85. 
Poole, F.G., Stewart, J.H., Palmer, A.R., Sandberg, C.A., Madrid, R.J., Ross, R.J. Jr., Hintze, L.F., Miller, M.M., and Wrucke, C.T., 1992, Latest Precambrian to latest Devonian time, development of a continental margin, in Burchfiel, B.C., Lipman, P.W., and Zoback, M.L., eds., The Cordilleran orogen, conterminous U.S.: Geological Society of America, The Geology of North America, v. G-3, p. 9-56.

Potter, C.J., Dickerson, R.P., Sweetkind, D.S., Drake, R.M. II, San Juan, C.A., Fridrich, C.J., and Day, W.C., 2002, Geologic map of the Yucca Mountain region: U.S. Geological Survey Miscellaneous Investigations Map I-2755, scale 1:50,000, 2 plates with pamphlet.

Potter, C.J., Sweetkind, D.S., Dickerson, R.P., and Killgore, M.L., 2002, Hydrostructural map of the Death Valley ground-water basin, Nevada and California: U.S. Geological Survey Miscellaneous Field Studies Map MF-2372 scale 1:350,000, 2 plates with pamphlet.

Pottorff, E.J., Erikson, S.J., and Campana, M.E., 1987, Hydrologic utility of borehole temperatures in Areas 19 and 20, Pahute Mesa, Nevada Test Site: University of Nevada, Desert Research Institute Publication 45060, 189 p.

Prothro, L.B., and Drellack, S.L. Jr., 1997, Nature and extent of lava-flow aquifers beneath Pahute Mesa, Nevada Test Site: Bechtel Nevada Report DOE/NV/11718-156 prepared for the U.S. Department of Energy, National Nuclear Security Administration Nevada Site Office, 50 p.

Quade, J., Mifflin, M.D., Pratt, W.L., McCoy, W., and Burckle, L., 1995, Fossil spring deposits in the southern Great Basin and their implications for changes in water-table levels near Yucca Mountain, Nevada, during Quaternary time: Geological Society of America Bulletin, v. 107, p. 213-230.

Reiner, S.R., 2007, Ground-water temperature data, Nevada Test Site and vicinity, Nye, Clark, and Lincoln Counties, Nevada, 2000-2006: U.S. Geological Survey Data Series 269, 20 p.

Reiner, S.R., Laczniak, R.J., DeMeo, G.A., Smith, J.L., Elliot, P.E., Nylund, W.E., and Fridrich, C.J., 2002, Ground-water discharge determined from measurements of evapotranspiration, other available hydrologic components, and shallow water-level changes, Oasis Valley, Nye County, Nevada: U.S. Geological Survey Water-Resources Investigations Report 01-4239, 65 p.

Robison, J.H., 1984, Ground-water level data and preliminary potentiometric surface maps, Yucca Mountain and vicinity, Nye County, Nevada: U.S. Geological Survey WaterResources Investigation Report 84-4197, 8 p.
Ruskauff, Greg, Ewing, John, Bhark, Eric, Mishra, Srikanta, Deeds, Neil, Beard, Tad, Rondeau, Richard, McCord, John, Aly, Alaa, Wolfsberg, Andrew, Soll, Wendy, Dash, Zora, and Gable, Carl, 2006, Groundwater flow model of Corrective Action Units 101 and 102-Central and Western Pahute Mesa, Nevada Test Site, Nye County, Nevada: StollerNavarro Joint Venture Report S-N/99205-076, 1101 p.

Sargent, K.A., and Stewart, J.H., 1971, Geologic map of the Specter Range NW quadrangle, Nye County, Nevada: U.S. Geological Survey Geologic Quadrangle Map GQ-884, scale 1:24,000.

Sass, J.H., Lachenbruch, A.H., Dudley, W.W. Jr., Priest, J.J., and Munroe, R.J., 1988, Temperature, thermal conductivity, and heat flow near Yucca Mountain, Nevada; some tectonics and hydrologic implications: U.S. Geological Survey Open-File Report 87-649, 118 p.

Savard, C.S., 1998, Estimated ground-water recharge from streamflow in Fortymile Wash near Yucca Mountain, Nevada: U.S. Geological Survey Water-Resources Investigations Report 97-4273, 30 p.

Sawyer, D.A., Fleck, R.J., Lanphere, M.A., Warren, R.G., Broxton, D.E., and Hudson, M.R., 1994, Episodic caldera volcanism in the Miocene southwestern Nevada volcanic field-Revised stratigraphic framework, 40Ar/39Ar geochronology, and implications for magmatism and extension: Geological Society of America Bulletin, v. 106, no. 10, p. 1304-1318.

Scott, R.B., and Bonk, Jerry, 1984, Preliminary geologic map of Yucca Mountain, Nye County, Nevada, with geologic sections: U.S. Geological Survey Open-File Report 84-494, scale 1:12,000, 9-p text.

Slate, J.L., Berry, M.E., Rowley, P.D., Fridrich, C.J., Morgan, K.S., Workman, J.B., Young, O.D., Dixon, G.L., Williams, V.S., McKee, E.H., Ponce, D.A., Hildenbrand, T.G., Swadley, W.C., Lundstrom, S.C., Ekren, E.B., Warren, R.G., Cole, J.C., Fleck, R.J., Lanphere, M.A., Sawyer, D.A., Minor, S.A., Grunwald, D.J., Laczniak, R.J., Menges, C.M., Yount, J.C., and Jayko, A.S., 1999, Digital geologic map of the Nevada Test Site and vicinity, Nye, Lincoln, and Clark Counties, Nevada, and Inyo County, California: U.S. Geological Survey Open-File Report 99-554A, 1 pl., scale 1:120,000, 53 p. accessed September 2007 at URL: http:// pubs.usgs.gov/of/1999/ofr-99-0554/.

Smith, R.L., and Bailey, R.A., 1968, Resurgent calderas: Geological Society of America Memoir 116, p. 613-662.

Snow, J.K., 1992, Large-magnitude Permian shortening and continental-margin tectonics in the southern Cordillera: Geological Society of America Bulletin, v. 104, p. 80-105. 
Snow, J.K., and Wernicke, B.P., 2000, Cenozoic tectonism in the central Basin and Range-Magnitude, rate, and distribution of upper crustal strain: American Journal of Science, v. 300, p. 659-719.

Soulé, D.A., 2006, Climatology of the Nevada Test Site: National Oceanic and Atmospheric Administration Air Resources Laboratory Technical Memorandum SORD 2006-3, 165 p.

Stewart, J. H., 1970, Upper Precambrian and Lower Cambrian strata in the southern Great Basin, California and Nevada: U.S. Geological Survey Professional Paper 620, 206 p.

Stewart, J. H., 1972, Initial deposits in the Cordilleran geosyncline; evidence of a late Precambrian ( 850 m.y.) continental separation: Geological Society of America Bulletin, v. 83, p. 1345-1360.

Stewart, J.H., and Poole, F.G., 1974, Lower Paleozoic and uppermost Precambrian Cordilleran miogeocline, Great Basin, western United States, in Dickinson, W.R., ed., Tectonics and sedimentation: Tulsa, Society of Economic Petrologists and Mineralogists, p. 27-57.

Stock, J.M., Healy, J.H., Hickman, S.H., and Zoback, M.D., 1985, Hydraulic fracturing stress measurements at Yucca Mountain, Nevada, and relationship to the regional stress field: Journal of Geophysical Research, v. 90, p. 8691-8706.

Stoller-Navarro Joint Venture, 2008, Modeling approach/ strategy for Corrective Action Unit 99: Rainier Mesa and Shoshone Mountain, Nevada Test Site, Nye County, Nevada: Stoller-Navarro Joint Venture Report S-N/99205_ 106, $102 \mathrm{p}$.

Sweetkind, D.S., Belcher, W.R., Faunt, C.C., and Potter, C.J., 2004, Geology and hydrology, in Belcher, W.R., ed., Chapter B of Death Valley regional ground-water flow system, Nevada and California-Hydrogeologic framework and transient ground-water flow model: U.S. Geological Survey Scientific Investigations Report 2004-5205, p. 27-98.

Sweetkind, D.S., Dickerson, R.P., Blakely, R., and Denning, P.D., 2001, Interpretive geologic cross sections for the Death Valley regional flow system and surrounding areas, Nevada and California: U.S. Geological Survey Miscellaneous Field Studies Map MF-2370, 3 plates, 32 pages of explanatory text.

Sweetkind, D.S. and du Bray, E.A., 2008, Compilation of Tertiary volcanic-rock stratigraphic thicknesses and caldera structures, east-central Nevada and west-central Utah: U.S. Geological Survey Digital Data Series DS-271, 40 p., plus GIS data.
Thordarson, William, 1965, Perched ground water in zeolitized-bedded tuff, Rainier Mesa and vicinity, Nevada Test Site, Nevada: U.S. Geological Survey Open-File Report 66-13, 90 p.

Tóth, J., 1962, A theory of groundwater motion in small drainage basins in Central Alberta, Canada: Journal of Geophysical Research, v. 67, no. 11, p. 4375-4387.

Trexler, J.H. Jr., Cole, J.C., and Cashman, P.H., 1996, Middle Devonian through Mississippian stratigraphy on and near the Nevada Test Site-Implications for hydrocarbon potential: American Association of Petroleum Geologists Bulletin, v. 80, p. 1736-1762.

Tucci, P., and Burkhardt, D.J., 1995, Potentiometric-surface map, 1993, Yucca Mountain and vicinity, Nevada: U.S. Geological Survey Water-Resources Investigations Report 95-4149, 15 p.

U.S. Department of Energy, 1997a, Regional groundwater flow and tritium transport modeling and risk assessment of the Underground Test Area, Nevada Test Site, Nevada: U.S. Department of Energy Report DOE/NV—477, 396 p.

U.S. Department of Energy, 1997b, Shaft and tunnel nuclear detonations at the Nevada Test Site: Development of a primary database for the estimation of potential interactions with the regional groundwater system: U.S. Department of Energy Report DOE/NV—464, 62 p.

U.S. Department of Energy, 1999a, Corrective action investigation plan for Corrective Action Unit 98Frenchman Flat, Nevada Test Site, Nevada: U.S. Department of Energy DOE/NV - 478-REV. 1, revision no. 1,219 p.

U.S. Department of Energy, 1999b, Corrective action investigation plan for Corrective Action Units 101 and 102-Central and western Pahute Mesa, Nevada Test Site, Nevada: U.S. Department of Energy DOE/NV—516, 350 p.

U.S. Department of Energy, 2000a, Corrective action investigation plan for Corrective Action Unit 97-Yucca Flat/Climax Mine, Nevada Test Site, Nevada: U.S. Department of Energy DOE/NV—659, 381 p.

U.S. Department of Energy, 2000b, United States nuclear tests, July 1945 through September 1992: U.S. Department of Energy Report DOE/NV—209 REV 15, 162 p.

U.S. Department of Energy, 2004, Corrective action investigation plan for Corrective Action Unit 99-Rainier Mesa/Shoshone Mountain, Nevada Test Site, Nevada: U.S. Department of Energy DOE/NV—1031, revision no. 0, $320 \mathrm{p}$. 
U.S. Geological Survey, 2009, USGS/U.S. Department of Energy cooperative studies in Nevada: Accessed October 8, 2009 at http://nevada.usgs.gov/doe nv/.

Waddell, R.K., Robison, J.H., and Blankennagel, R.K., 1984, Hydrology of Yucca Mountain and vicinity, NevadaCalifornia-Investigative results through mid 1983: U.S. Geological Survey Water-Resources Investigations Report 84-4267, $72 \mathrm{p}$.

Warren, R.G., Cole, G.L., and Walther, D., 2000, A structural block model for the three-dimensional geology of the southwestern Nevada volcanic field: Los Alamos National Laboratory Report LA-UR-00-5866, $82 \mathrm{p}$.

Winograd, I.J., 1970, Noninstrumental factors affecting measurement of static water levels in deeply buried aquifers and aquitards, Nevada Test Site: Ground Water, v. 8, no. 2, p. 19-28.

Winograd, I.J., and Pearson, F.J. Jr., 1976, Major carbon 14 anomaly in a regional carbonate aquifer-Possible evidence for megascale channeling, south-central Great Basin: Water Resources Research, v. 12, p. 1125-1143.
Winograd, I.J., and Thordarson, William, 1975, Hydrogeologic and hydrochemical framework, south-central Great Basin, Nevada-California, with special reference to the Nevada Test Site: U.S. Geological Survey Professional Paper 712-C, $126 \mathrm{p}$.

Wood, D.B., 2007, Digitally available interval-specific rocksample data compiled from historical records, Nevada Test Site and vicinity, Nye County, Nevada: U.S. Geological Survey Data Series 297, 56 p.

Workman, J.B., Menges, C.M., Page, W.R., Taylor, E.M., Ekren, E.B., Rowley, P.D., Dixon, G.L., Thompson, R.A., and Wright, L.A., 2002, Geologic map of the Death Valley ground-water model area, Nevada and California: U.S. Geological Survey Miscellaneous Field Studies Map MF-2381-A, 1 pl., scale 1:250,000, 56 p. accessed September 2007 at URL: http://pubs.usgs.gov/mf/2002/ $\underline{\mathrm{mf}-2381 / .}$.

Zhu, Jianting, Pohlmann, K.F., Chapman, J.B., Russell, C.E., Carroll, R.W.H., and Shafer, D.S., 2009, Uncertainty and sensitivity of contaminant travel times from the upgradient Nevada Test Site to the Yucca Mountain area: Desert Research Institute Publication No. 45230, 245 p. 
This page intentionally left blank. 


\section{Appendix 1. Water Levels Measured in the Nevada Test Site Area, Nevada, 1941-2008.}

Hydrographs and locations for the 1,108 wells that have measured water levels in the Nevada Test Site area are tabulated and can be displayed interactively from a Microsoft ${ }^{\circledR}$ Excel workbook. The workbook is designed to be an easy-to-use tool to view water levels and other associated information for wells in the study area. Information for an individual well can be selected by using the AutoFilter option available in Excel. The information presented for a selected well includes:

- USGS site identification number,

- Well name,

- Land-surface altitude,

- Water-level date,

- Water-level depth,

- Water-level altitude,

- Water-level qualifier,

- Water-level source,

- Water-level method,

- Water-level status,

- Water-level remark,

- Map flag,

- NTS area number,

- Latitude, and

- Longitude.

Appendix 1 data are available at http://pubs.usgs.gov/pp/1771 


\section{Appendix 2. Mean Water Levels, Hydraulic Heads, Well Characteristics, and Selected Water Temperatures for Wells Used to Develop Potentiometric Contours in the Nevada Test Site Area.}

A summary table that includes the 800 wells used to develop potentiometric contours in the Nevada Test Site area is available in a Microsoft $\AA$ Excel workbook. For each well, the mean of the water levels considered representative of predevelopment conditions and the calculated hydraulic head is presented. Temperature adjustments to water levels and information relevant to adjusting water levels for temperature also are documented. The information presented for each well includes:

- Well name,

- USGS site identification number,

- Borehole name,

- NTS Red Book hole number,

- Latitude,

- Longitude,

- Land-surface altitude,

- Land-surface altitude accuracy,

- Depth drilled,

- Well depth,

- Top and bottom opening altitude,

- Number of water levels,

- Water-level date range,

- Mean water-level altitude,

- Hydraulic-head estimate,

- Was a temperature adjustment applied,

- Are potential temperature-adjustment errors greater than $5 \mathrm{ft}$,

- Mean water-column temperature,

- Water-column length,

- Contributing subsurface hydrologic unit types,

- Map use of hydraulic head

Appendix 2 data are available at http://pubs.usgs.gov/pp/1771 


\section{Appendix 3. Hydrostratigraphic Units and Subsurface Hydrologic Unit Types for Wells in the Nevada Test Site Area, as Projected from Hydrostratigraphic Framework Models.}

The hydrostratigraphic units (HSUs) and corresponding subsurface hydrologic unit types (SHUTs) for the 800 wells identified as having one or more water-level measurements representative of predevelopment groundwater conditions are tabulated and can be displayed interactively from a Microsoft ${ }^{\circledR}$ Excel workbook. The workbook is designed to view a stratigraphic column interpreted from a hydrostratigraphic framework model, the mean predevelopment water-level altitude, and basic well-construction information for wells in the study area. Information for an individual well can be viewed by selecting the well from a column-header dropdown list.

Appendix 3 data are available at http://pubs.usgs.gov/pp/1771 
54 Groundwater Flow Systems—Potentiometric Contours, Hydrostratigraphy, and Geologic Structures, Nevada Test Site

This page intentionally left blank. 
Publishing support provided by the U.S. Geological Survey Publishing Network, Tacoma Publishing Service Center

For more information concerning the research in this report, contact the Director, Nevada Water Science Center

U.S. Geological Survey

2730 N. Deer Run Road

Carson City, Nevada 89701

http://nevada.usgs.gov/water/index.htm 


\section{奇}

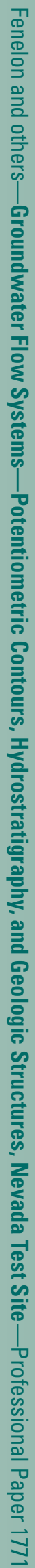

